\section{LONG-TERM SURVEILLANCE PLAN FOR THE FALLS CITY DISPOSAL SITE, FALLS CITY, TEXAS}

June 1995

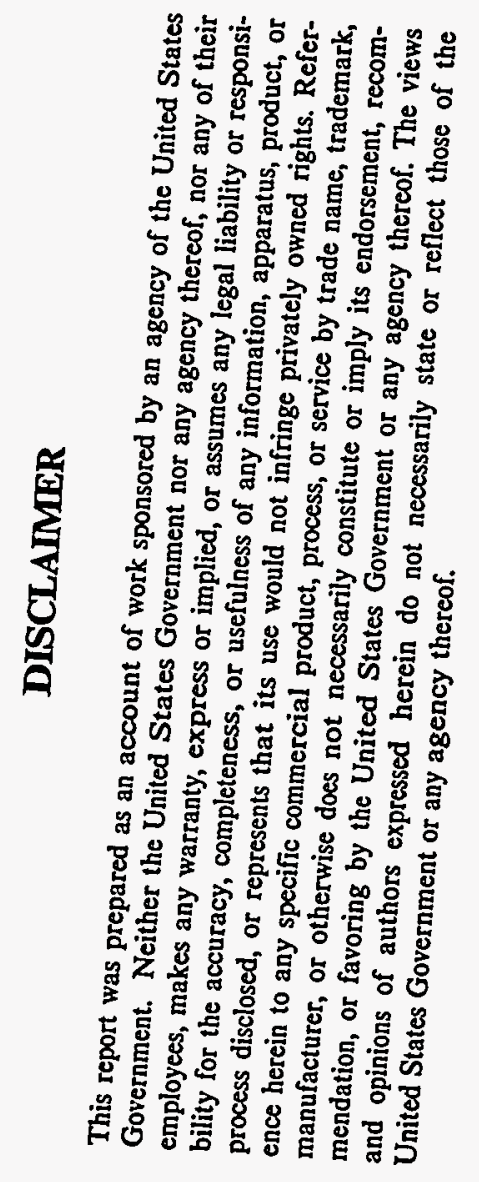

\author{
Prepared for \\ U.S. Department of Energy \\ UMTRA Project \\ Albuquerque, New Mexico \\ Prepared by \\ Jacobs Engineering Group Inc. \\ Albuquerque, New Mexico
}

\section{RECEN/FD JUL 281995 \\ OSTI}

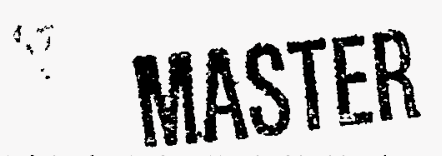

UISTABUTION OF THS OOCUMENT IS UNLLMITED 


\section{DISCLAIMER}

Portions of this document may be illegible in electronic image products. Images are produced from the best available original document. 


\section{TABLE OF CONTENTS}

Section

Page

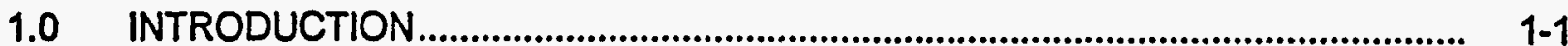

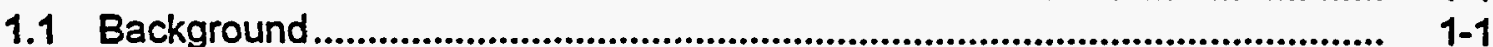

1.2 Licensing process ................................................................................ 1-2

1.3 Long-term surveillance plan ............................................................... 1-2

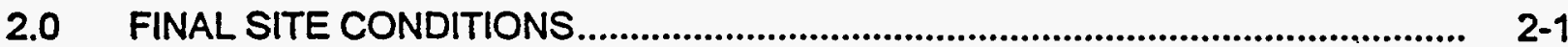

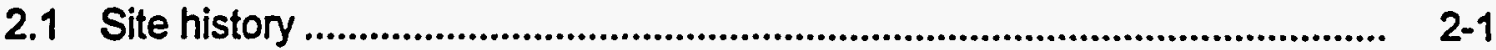

2.2 Description and location of the disposal site area .................................... 2-1

2.2.1 Disposal site access and security.................................................... 2.. 2-4

2.2.2 Disposal cell design.......................................................................... 2-5

3.0 SITE DRAWINGS AND PHOTOGRAPHS ......................................................

3.1 Disposal site map................................................................................ $3-1$

3.2 Disposal site as-built drawings ........................................................ $3-2$

3.3 Site baseline photographs................................................................. 3-2

3.4 Site aerial photographs ........................................................................ $3-2$

3.5 Site inspection photographs...................................................... $\quad 3-2$

4.0 PERMANENT SITE-SURVEILLANCE FEATURES......................................... $4-1$

4.1 Survey monuments ........................................................................... 4-1

4.2 Boundary monuments. ..................................................................... 4-1

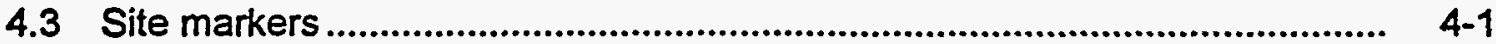

4.4 Entrance and perimeter signs ........................................................... 4-7

4.5 Settlement plates .............................................................................. $4-7$

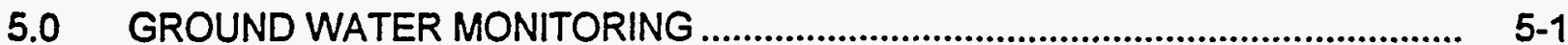

5.1 Ground water characterization ............................................................ $5-1$

5.1.1 Hydrostratigraphy .......................................................................... 5-1

5.1.2 Background ground water quality................................................... 5-5

5.2 Ground water monitoring plan.................................................................. $5-18$

5.2.1 Monitoring well network................................................................ 5-18

5.2.2 Sampling frequency .................................................................... 5-19

5.2.3 Monitored constituents .................................................................... 5-19

5.2.4 Screening monitoring and exceedance .............................................. 5-23

5.3 Corrective action ....................................................................................... 5-25

5.4 Data validation and quality assurance................................................... 5-25

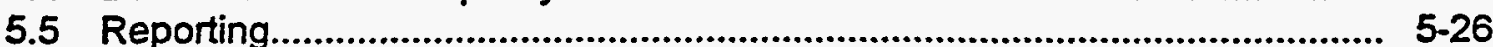




\section{TABLE OF CONTENTS (Continued)}

Section

Page

6.0 SITE INSPECTIONS ................................................................. 6-1

6.1 Inspection frequency ........................................................... 6-1

6.2 Inspection team ....................................................................... 6-1

6.3 Preparation for inspection........................................................... $6-2$

6.4 Site inspection and inspection checklist ........................................ $6-2$

6.4.1 Off-site areas ..................................................................... 6-3

6.4.2 On-site areas .................................................................. 6-3

6.5 Modifying processes ................................................................. 6-4

5.6 Vegetation............................................................................... $6-5$

6.6.1 Planned vegetation ......................................................... 6-5

6.6 .2 Volunteer plant growth .................................................... 6-5

6.7 Site inspection map .................................................................. 6-6

6.8 Reporting requirements ...................................................... $6-6$

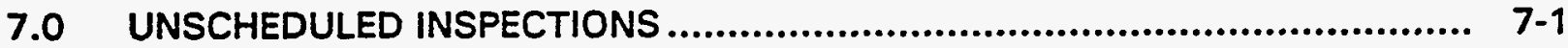

7.1 Follow-up inspections .......................................................... $7-1$

7.2 Contingency inspections ........................................................ $7-1$

8.0 CUSTODIAL MAINTENANCE OR REPAIR............................................ 8-1

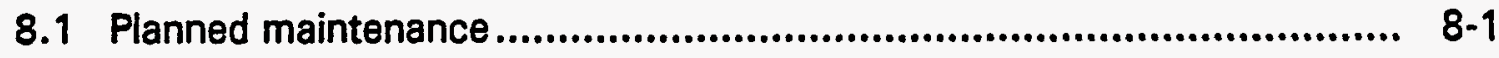

8.2 Unscheduled maintenance or repair ........................................... 8-1

8.3 Certification and reporting requirements.......................................... 8-1

9.0 CORRECTIVE ACTION............................................................... 9-1

9.1 Problem identification ................................................................ $9-4$

9.2 Certification and reporting procedures ........................................ $9-4$

10.0 RECORD KEEPING AND REPORTING REQUIREMENTS $\ldots \ldots \ldots \ldots \ldots \ldots \ldots \ldots \ldots \ldots . \ldots 10 . \ldots \ldots$

10.1 Records.................................................................................. 10-1

10.2 Reports .......................................................................... 10-2

11.0 EMERGENCY NOTIFICATION AND REPORTING.................................. 11-1

11.1 Agency agreements ................................................................... 11-1

11.2 Unusual occurrences ................................................................ 11-1

11.3 Earthquakes............................................................................. 11-1

11.4 Meteorological events........................................................... 11-2

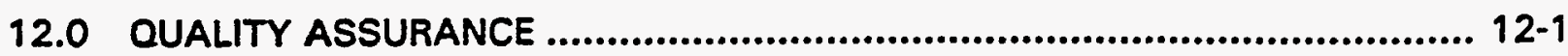

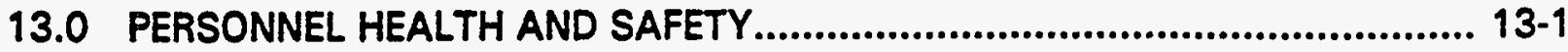

13.1 Health and safety inspections ................................................... 13-1

13.2 Reportable incidents ........................................................... 13-2 
TABLE OF CONTENTS (Concluded)

Section

Page

14.0 LIST OF CONTRIBUTORS

14-1

15.0 REFERENCES.

15-1

ATTACHMENT 1

ATTACHMENT 2

ATTACHMENT 3

ATTACHMENT 4

ATTACHMENT 5
SITE OWNERSHIP/CUSTODY DOCUMENTATION

NRC CONCURRENCE AND LICENSING DOCUMENTATION

SITE INSPECTION PHOTO LOG

SITE INSPECTION CHECKLIST

AGENCY NOTIFICATION AGREEMENTS 


\section{LIST OF FIGURES}

Figure

Page

2.1 Area map of tailings piles and ponds, Falls City, Texas, site

2.2 Disposal site location map, Falls City, Texas

4.1 UMTRA Project survey monument, Falls City, Texas, site.

4.2 UMTRA Project boundary monument, Falls City, Texas, site

4.3 UMTRA Project site marker at entrance of disposal site . Falls City,

Texas, site

4.4 UMTRA Project site marker at crest of disposal cell, Falls City, Texas, site

4.5 UMTRA Project site marker incised message, Falls City, Texas, site

4.6 UMTRA Project entrance sign and message, Falls City, Texas, site

4.7 UMTRA Project perimeter sign and message, Falls City, Texas, site

4.8 UMTRA Project settlement plates, Falls City, Texas, site

5.1 Surface geology and cross section location, Falls City, Texas, site .............. 5-2

5.2 Cross section (A-A') of uppermost aquifer, Falls City, Texas, site.

5.3 Locations of monitor wells, former tailings piles, and disposal cell,

Falls City, Texas, site

5-8

5.4 Locations of the Dilworth background wells and the Deweesville/

Conquista Conoco 600 series wells, Falls City, Texas, site.

9.1 Corrective action flowchart, UMTRA Project long-term surveillance program

9.2 Key elements in the corrective action process.

\section{LIST OF PLATES}

PLATE 1 FINAL DISPOSAL SITE SURVEY MAP

PLATE 2 FALLS CITY DISPOSAL SITE MAP 


\section{LIST OF TABLES}

Table

2.1 Falls City disposal site key holders

3.1 Aerial photography specifications for the Falls City, Texas, disposal site ........

5.1 Typical water quality data for Dilworth and Deweesville/Conquista background wells.

5.2 Water quality in the Deweesville/Conquista aquifer at the Falls City, Texas, site

5.3 Statistical summary of the Dilworth background ground water quality data at the Falls City, Texas, site

5.4 Ground water monitoring network, Falls City, Texas, site ........................ 5-18.

5.5 Filtered water quality of tailings fluids at the Falls City, Texas, site ............. 5-21

5.6 Monitored constituents for establishing baseline conditions at the Falls City, Texas, disposal site 


\section{LIST OF ACRONYMS}

Acronym

\section{Definition}

bls below land surface

DOE

DQO

EA

U.S. Department of Energy

data quality objective

environmental assessment

EPA

FM

FOD

GJPO

LTSP

U.S. Environmental Protection Agency

$M C L$

MSL

NRC

QA

QC

Ra-226

farm-to-market roads

frequency of detection

Grand Junction Projects Office

long-term surveillance plan

maximum concentration limit

mean sea level

U.S. Nuclear Regulatory Commission

quality assurance

quality control

RAC

RAP

SOP

SOW

TAC

radium-226

Remedial Action Contractor

remedial action plan

standard operating procedure

statement of work

UMTRA

Technical Assistance Contractor

UMTRCA

Uranium Mill Tailings Remedial Action

UPDCC

Uranium Mill Tailings Radiation Control Act

USGS

UMTRA Project Document Control Center

U.S. Geological Survey 


\subsection{INTRODUCTION}

This long-term surveillance plan (LTSP) for the Uranium Mill Tailings Remedial Action (UMTRA) Project Falls City disposal site, Falls City, Texas, describes the surveillance activities for the disposal site. The U.S. Department of Energy (DOE) will carry out these activities to ensure that the disposal cell continues to function as designed. This LTSP was prepared as a requirement for acceptance under the U.S. Nuclear Regulatory Commission (NRC) general license for custody and long-term care of residual radioactive materials. This LTSP documents whether the land and interests are owned by the United States and details how long-term care of the disposal site will be carried out. It is based on the DOE's Guidance for Implementing the UMTRA Project Long-term Surveillance Program (DOE, 1992a).

\subsection{BACKGROUND}

Title I of the Uranium Mill Tailings Radiation Control Act (UMTRCA) of 1978 (42 USC $\$ 7901$ et seq.) authorized the DOE to perform remedial actions at 24 inactive uranium mill tailings sites to reduce the potential effect on public health from the unstabilized residual radioactive materials in and around the uranium mill tailings. Residual radioactive materials are any wastes that the DOE determines to be radioactive, either in the form of tailings resulting from the processing of ores for the extraction of uranium and other valuable constituents of the ores, or in other forms that relate to such processing, such as sludge and captured contaminated water from these sites (60 FR 2854). The Falls City, Texas, uranium mill tailings site in Karnes County was one of the 24 sites identified for remediation in the UMTRCA. The DOE, NRC, and the state of Texas entered into a cooperative agreement under the UMTRCA, establishing terms and conditions of the remedial action (DOE Cooperative Agreement No. DE-FC04-87AL20532, 2 February 1989) (DOE, 1989). Remedial action that consolidated contaminated materials and placed them in a disposal cell was completed in May 1994. During remediation 7 million tons $(6.4$ million tonnes) of mill tailings and contaminated soil were placed in the disposal cell.

Placement of the radon/infiltration barrier, erosion protection layers, and revegetation activities, begun late in 1993, were completed in early 1994. The NRC and the state of Texas concurred with the DOE's remedial action plan (RAP) (DOE, 1992b) to comply with the requirements of the U.S. Environmental Protection Agency's (EPA) standards in 40 CFR Part 192 and final ground water standards in 60 FR 2854. These standards were promulgated by the EPA in 1983 (40 CFR Part 192), portions were revised, and on January 11, 1995, a final rule was published in the Federal Register (60 FR 2854). Environmental impacts associated with the remedial action were evaluated in an environmental assessment (EA) (DOE, 1991 ) prepared by the DOE. The UMTRA Ground Water Project will address the residual ground water contamination at the Falls City site. 


\subsection{LICENSING PROCESS}

The NRC has developed regulations 10 CFR $\$ 40.27$ for the issuance of a general license for the long-term care of DOE UMTRA (Title 1) disposal sites, including the Falls City disposal site. The license is available only to the DOE (or any successor federal agency designated by the President) and has no termination date. The purpose of this general license is to ensure that the UMTRA disposal sites will be cared for in a manner that protects the public health and safety and the environment. The license is granted after the remedial action is selected and performed with NRC concurrence and in consultation with the state (i.e., acceptance of the site-specific completion report and certification summary) and when the NRC formally accepts the site-specific LTSP that meets the requirements of 10 CFR $\$ 40.27$. The site-specific completion report documents the site as-built conditions. The DOE prepares a certification summary memorandum that certifies remedial action is in compliance with RAP provisions and EPA standards. The DOE compiles the final completion report, final audit report, and certification summary into the certification report and submits it to the NRC and state for concurrence (DOE, 1993). Concurrence from the NRC on the certification report will be included as Attachment 1 when received.

When the general license becomes effective, following acceptance of the LTSP, responsibility for the long-term surveillance program will be transferred to the DOE Grand Junction Projects Office (GJPO) in Grand Junction, Colorado. The programmatic transfer will occur within 30 days of NRC notification that the license is in effect.

\section{Acquisition}

The state of Texas currently owns the Falls City site. The title documentation is being reviewed by the U.S. Army Corps of Engineers prior to transfer of the site to the federal government. This is done to ensure that title to the property is consistent with U.S. Department of Justice standards.

Attachment 1 provides a legal description of the Falls City disposal site to be conveyed to the DOE for long-term care and ownership. See Plate 1 for the final disposal site survey map.

\subsection{LONG-TERM SURVEILLANCE PLAN}

This document describes the long-term surveillance program to be implemented at the Falls City disposal site to ensure that the disposal site continues to perform as designed. This plan is based on the DOE's Guidance for Implementing the UMTRA Project Long-term Surveillance Program (DOE, 1992a). 
This LTSP meets the requirements under 10 CFR $\$ 40.27$ by addressing the following:

- Site description and ownership.

- Description of final site conditions.

- Site inspection procedures and personnel.

- Custodial maintenance and corrective actions programs.

- Record keeping and reporting.

- Quality assurance (QA).

- Emergency response. 


\subsection{FINAL SITE CONDITIONS}

\subsection{SITE HISTORY}

Susquehanna Western, Inc., built and operated a uranium mill at the Falls City site from April 1961 until August 1973. The mill used a sulfuric acid leach extraction process to treat approximately 2.5 million tons ( 2.3 million tonnes) of ore averaging 0.16 percent uranium oxide; more than 700 tons (600 tonnes) of uranium oxide were sold to the U.S. Atomic Energy Commission while the mill was in operation. More than 3.1 million tons $(2.8$ million tonnes of tailings were discharged to ponds (Figure 2.1).

Tailings and processing solutions from the Susequehanna Western, Inc., milling operation were impounded in separate ponds, four of which had been open pit mines excavated into the ore-bearing sandstone. The tailings ponds were 30 to 35 feet (ft) ( 9 to 11 meters [m]) deep and unlined, except for the naturally clayey foundation soils and sediments.

In 1975, Susequehanna Western, Inc., sold the mill site and residual materials to Tepcore, Inc., who in turn sold the property to Solution Engineering, Inc., and its partner Basic Resource, Inc. From late 1978 to early 1982, Solution Engineering, Inc., conducted secondary solution mining of uranium from four of the tailings piles (piles 1, 2, 4, and 7 in Figure 2.1). The operation included a system of shallow injection/recovery wells and an ion exchange treatment system to recover uranium and molybdenum from solution. The uranium leaching agent was acid water from the pond formerly located on pile 7. Residual process waters were pumped back to this pond. All ponds were evaporated except for pond 6, which is thought to have been recharged by natural seepage. Spent filter carbon, extracted molybdenum, and calcium carbonate wastes were stored in drums for eventual off-site disposal or dumped into a small pit adjacent to the northern border of tailings pile 1 .

\subsection{DESCRIPTION AND LOCATION OF THE DISPOSAL SITE AREA}

The Falls City disposal site is in Karnes County, Texas, approximately 8 miles (mi) (13 kilometers [km]) southwest of the town of Falls City and $46 \mathrm{mi}(74 \mathrm{~km})$ southeast of San Antonio, Texas (Figure 2.2).

The disposal site consisted of two parcels: Parcel $A$ (the former mill site, one mill building, five tailings piles (piles $1,2,4,5$, and 7 ), and one tailings pond (pond 6) northwest of the intersection of Farm-to-Market Roads 1344 IFM1344] and FM-791) (Figure 2.1). Parcel A was fenced and was 473 acres (ac) (191 hectares (hal). A sixth tailings pile (pile 3 ) was north, northeast of this intersection; this area was designated Parcel B. Parcel B was 120 ac (49 ha). Windblown contamination was adjacent to both parcels, 298 ac (121 ha) at 


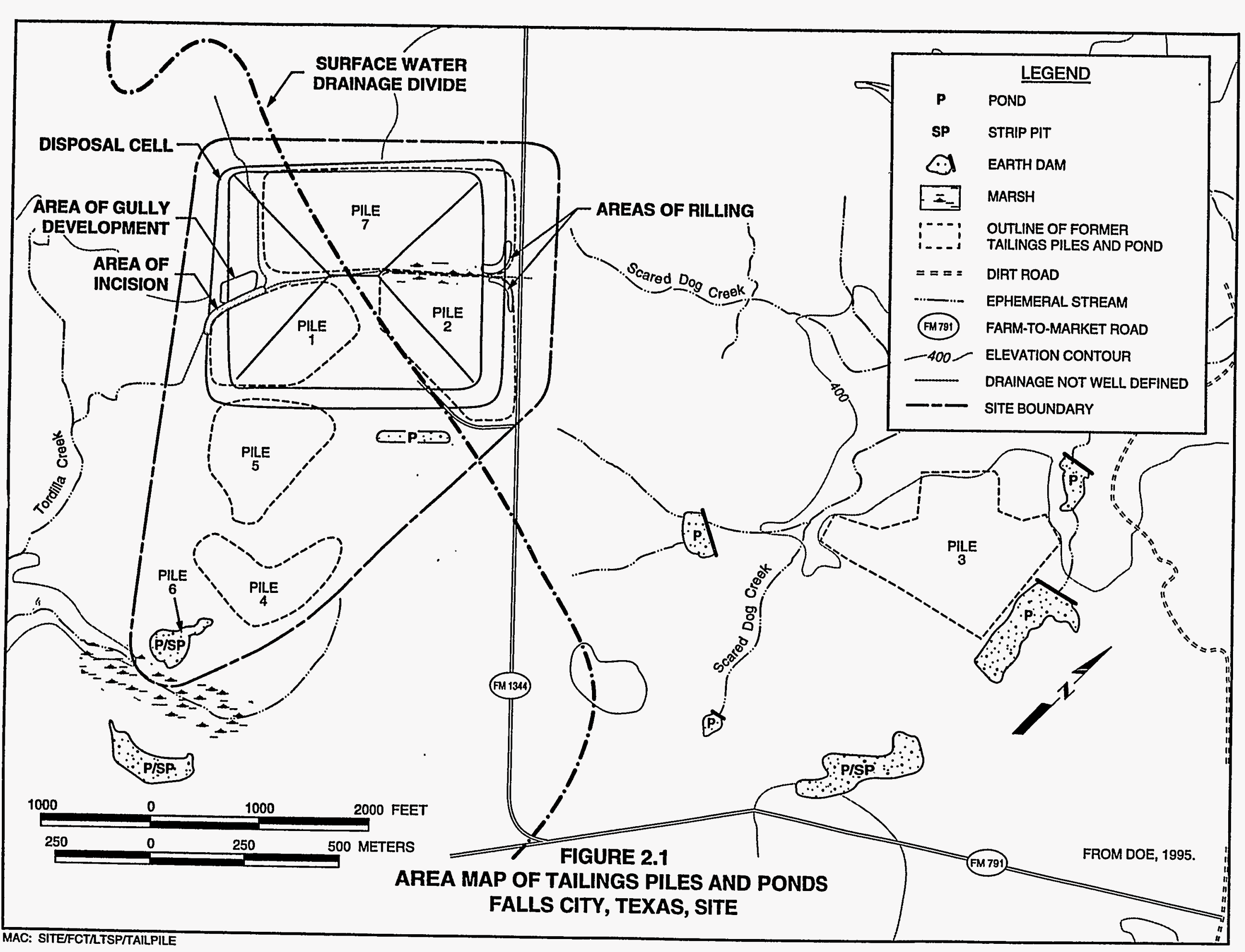




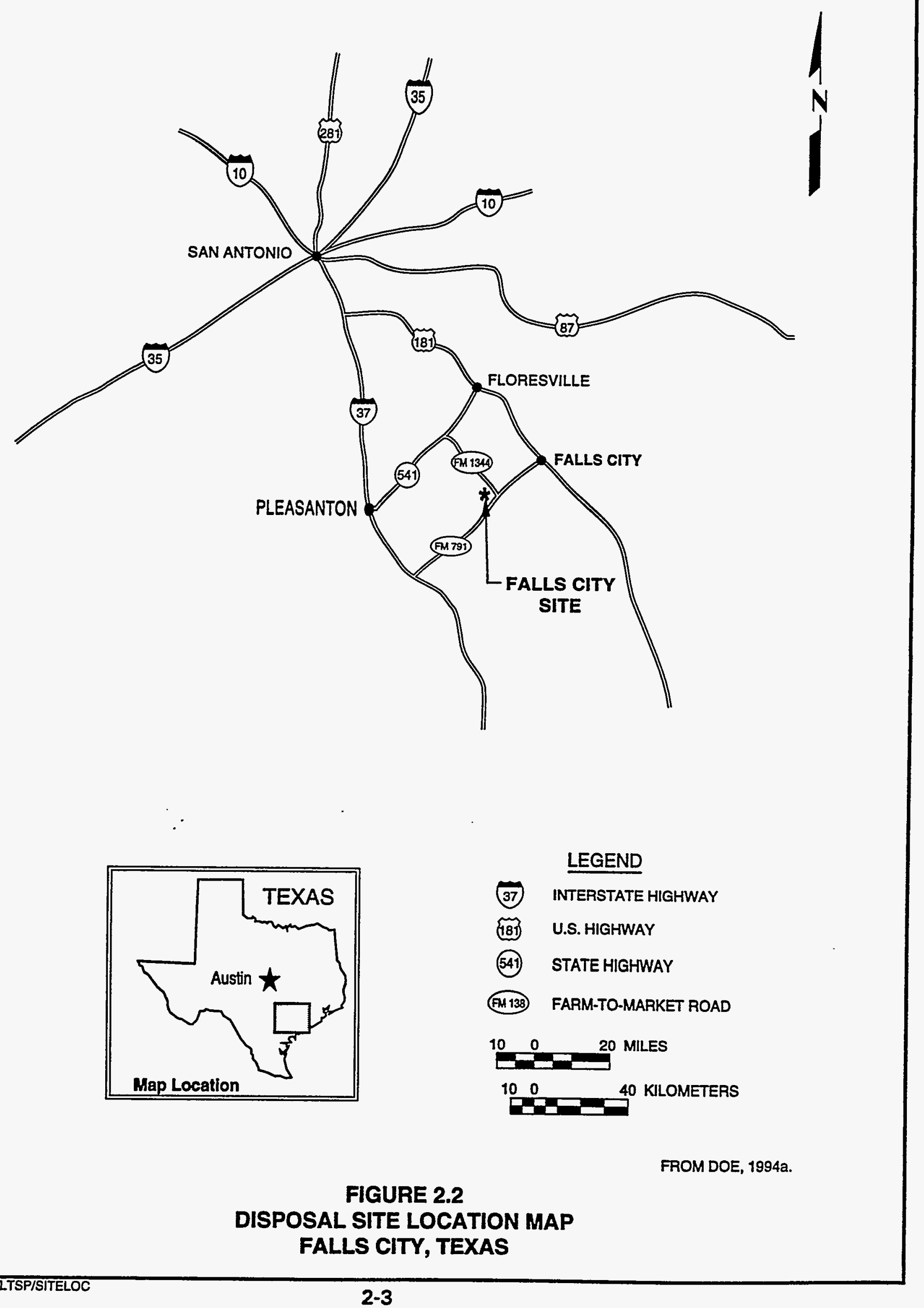


Parcel $A$ and 80 ac ( 32 ha) at Parcel B. An estimated $5,764,100$ cubic yards $\left(\mathrm{yd}^{3}\right)\left(4,407,200\right.$ cubic meters $\left.\left[\mathrm{m}^{3}\right]\right)$ of residual radioactive materials were within both parcels. The two parcels are approximately $1 \mathrm{mi}(1.6 \mathrm{~km})$ apart.

\subsubsection{Disposal site access and security}

The Falls City site can be accessed by following these directions:

- From San Antonio, Texas, take U.S. Highway 37 (US-37) south to US-181.

- Go southeast on US-181.

- From US-181, turn right onto FM-791 and travel southwest for $7.5 \mathrm{mi}$ (12 $\mathrm{km})$.

- Turn right onto FM-1344. The site is on the southern side of FM-1344.

Keys to the Falls City disposal site are maintained by the DOE Project Site Manager, the Technical Assistance Contractor (TAC) UMTRA Project Manager, and the GJPO supervisory general engineer (Table 2.1).

Because of the remote location of the disposal site, purposeful intrusion is not expected to be a problem. However, if intrusion, vandalism, or other factors (e.g., grazing) become a problem, site security will be reevaluated.

Table 2.1 Falls City disposal site key holders

\begin{tabular}{|c|c|c|}
\hline Title and current contact & Telephone & Address \\
\hline DOE Project Site Manager & $(505) 845-4022$ & $\begin{array}{l}\text { U.S. Department of Energy } \\
\text { UMTRA Project } \\
\text { Environmental Restoration Division } \\
2155 \text { Louisiana NE, Suite } 4000 \\
\text { Albuquerque, NM } 87110\end{array}$ \\
\hline TAC UMTRA Project Manager & $(505) 888-1300$ & $\begin{array}{l}\text { Jacobs Engineering Group Inc. } \\
2155 \text { Louisiana NE, Suite } 10,000 \\
\text { Albuquerque, NM } 87110\end{array}$ \\
\hline GJPO Supervisory General Engineer & $(970) 248-6006$ & $\begin{array}{l}2597 \text { B } 3 / 4 \text { Road } \\
\text { Grand Junction, CO } 81503\end{array}$ \\
\hline
\end{tabular}

The effectiveness of site security measures (e.g., fence condition, locked gate, etc.) will be monitored through scheduled site inspections (Section 6.4). A DOE 24-hour telephone number on the entrance sign (Section 4.4) and agreements 
with local agencies to notify the DOE in the event of an emergency or breach of site integrity (Section 11.0) provide additional security measures.

\subsubsection{Disposal cell design}

The disposal cell is located at the head of a surface water divide, thus it will not be impacted by watershed runoff or flow in nearby intermittent steams. The area surrounding the disposal cell was regraded and revegetated to minimize rill and gully formation caused by sheet-flow runoff from the cell.

The stabilized disposal cell was constructed above the ground surface; it contains $7,143,000$ tons $(6,480,000$ tonnes) of compacted tailings and contaminated soil. The dimensions of the disposal cell are approximately 2600 $\mathrm{ft}(790 \mathrm{~m})$ by $2200 \mathrm{ft}(670 \mathrm{~m})$, including a 20-ft $(6-\mathrm{m})$ wide toe apron (Plate 2). The maximum elevation of the cell is $487 \mathrm{ft}(148 \mathrm{~m})$ above mean sea level (MSL).

Relocated contaminated materials were placed on in situ tailings and the foundation soil, then covered with a clayey soil (radon/infiltration barrier). The topslopes of the disposal cell were seeded with grass and the sideslopes were capped with rock to prevent wind and water erosion of the underlying radon/infiltration barrier and tailings.

A 36-inch (910-mm)-thick radon/infiltration barrier was placed over the contaminated materials. This barrier was constructed of clayey soil and is designed to reduce the radon flux from the disposal cell to less than 20 picocuries per square meter per second $\left(\mathrm{pCi} / \mathrm{m}^{2} / \mathrm{s}\right)$ and minimize the rate of surface water infiltration into the tailings. Because the daily temperature in the Falls City area is warm year round, the radon/infiltration barrier will not be affected by freezing and thawing cycles.

The vegetated topslope is designed to return water from precipitation to the atmosphere by evapotranspiration, and the 36-inch $(910-\mathrm{mm})$-thick soil and topsoil layer can store water during periods when precipitation exceeds evapotranspiration. The erosion protection layer on the top slope of the disposal cell is a 30-inch (760 millimeter [mm])-thick layer of soil; 6-inch (150 mm)-thick layer of topsoil, and vegetation. The maximum grade of the topslopes is one percent.

The erosion protection layer on the sideslopes is riprap with a median rock diameter $\left(D_{50}\right)$ of about 7 inches $(180 \mathrm{~mm})$. A 6-inch $(150-\mathrm{mm})$-thick bedding layer was placed between the riprap and the radon/infiltration barrier to prevent damage to the barrier by rocks and loss of the fined-grained radon/infiltration barrier material. The maximum grade of the sideslopes is 5 horizontal to 1 vertical (20 percent). Also, the 20-percent sideslopes, in conjunction with the bedding layer, will allow excess surface water to run off the disposal cell. The components of both the topslope and sideslope covers are intended to minimize 
the potential for deep percolation of precipitation into the tailings contaminated materials.

At the toe of the disposal cell there is a rock apron, varying in thickness from 76 inches $(1930 \mathrm{~mm})$ to 118 inches $(2997 \mathrm{~mm})$, was constructed of Type C riprap. The $D_{50}$ size for Type $C$ riprap is about 11 inches $(280 \mathrm{~mm})$. At the ground surface, riprap protection extends $20 \mathrm{ft}(6 \mathrm{~m})$ from the toe of the disposal cell.

The surface conditions of the disposal cell will be monitored during yearly inspections to determine whether the disposal cell and erosion protection components of the cell are performing as intended. General guidelines to be followed when inspecting the disposal cell are presented in Section 6.0. 


\subsection{SITE DRAWINGS AND PHOTOGRAPHS}

At the completion of remedial action, disposal site as-built conditions were documented with as-built drawings and photographs (MKF, 1995). This information illustrates baseline conditions for comparison to future disposal site conditions.

A disposal site topographic map was prepared by the remedial action contractor (RAC). This map will become part of the Falls City permanent site file. The site inspection map will be updated, as necessary, after each site inspection. All drawings, disposal site map, and photographs will be archived by the UMTRA Project Document Control Center (UPDCC). The topographic map, disposal site map drawings, and photographs may be further modified by the GJPO, as necessary, and the GJPO will be responsible for maintaining and archiving these maps, drawings, and photographs after the Falls City permanent site file is transferred to the GJPO.

\subsection{DISPOSAL SITE MAP}

The Falls City disposal site map was compiled from a final topographic map of the disposal site area. The final topographic survey was conducted in accordance with the standards of the Manual of Photogrammetry (ASP, 1980). The following specifications were used in developing the map: a scale of 1 inch $=400 \mathrm{ft}(1 \mathrm{~mm}=4.8 \mathrm{~m})$, a contour interval of $2 \mathrm{ft}(0.6 \mathrm{~m})$, and coverage of the disposal site and an area of $0.25 \mathrm{mi}(0.4 \mathrm{~km})$ around the site perimeter from the site boundary.

In addition to topography, the map defines the following:

- Disposal site property boundaries, fences, gates, and access roads.

- Outline of the toe and crest of the disposal cell.

- Location and extent of rock cover (riprap), including rock toe drains.

- Ground water monitor wells and access roads.

- Survey control stations.

- Permanent site surveillance features (e.g., monuments, markers, and signs).

- Other surveillance features (e.g., settlement plates).

- Site coordinate system.

When the Falls City disposal site map is updated, the revised map will include the year of revision and the revision number. The Falls City disposal site map will serve as the base map for site inspections (Section 6.7). A new, separate inspection map will be prepared after each inspection. Each site inspection map will indicate the year of the inspection and the type of inspection. The Falls City disposal site base map and periodic disposal site inspection maps will become part of the Falls City permanent site file. 
A set of as-built drawings provided by Morrison Knudsen-Ferguson, the RAC, illustrates final disposal cell construction and final disposal site conditions. These drawings were used to prepare the Falls City disposal site topographic map. They may be used to document changes in physical site conditions or the disposal cell over time and to develop corrective action plans, if required.

At licensing, the RAC. will transfer one original set of as-built drawings to the GJPO. These drawings will be filed and maintained in the Falls City permanent site file at the GJPO.

\subsection{SITE BASELINE PHOTOGRAPHS}

A photographic record of the final site conditions at the Falls City disposal site will be included and maintained in the Falls City permanent site file. This record consists of a series of aerial and ground photographs that provide a baseline visual record of final site construction and final site conditions to complement the as-built drawings. In addition, the final completion report for the disposal site contains a complete set of photographs that documents each phase of construction (MKF, 1995). The post-construction photographs provide an orientation tool for site inspections and a baseline record of surveillance features.

\subsection{SITE AERIAL PHOTOGRAPHS}

A set of aerial photographs was taken of the Falls City disposal site after surface remedial action was completed on 27 July 1994. This set of photographs provides a permanent record of site conditions, enabling inspectors to monitor changes in site conditions (e.g., erosion patterns, vegetation changes, and land use) over time. The photographs are a useful orientation tool for disposal site inspections. The need for.new aerial photographs will be ovaluated at 5-year intervals, beginning the year the site license becomes effective. Table 3.1 summarizes the specifications for aerial photographs at the Falls City disposal site. More detailed guidance is provided in Attachment 3 of the Guidance for Implementing the UMTRA Project Long-term Surveillance Program (DOE, 1992a).

\subsection{SITE INSPECTION PHOTOGRAPHS}

Photographs will be taken during disposal site inspections to document conditions at the disposal cell and the disposal site. These photographs will provide a continuous record for monitoring changing conditions over time. The photographs can be compared with the baseline photographs to monitor site integrity. 
Table 3.1 Aerial photography specifications for the Falls City, Texas, disposal site

Area to be photographed

Products to be delivered

Flight date

Camera

Film

Filter

Flight line coverage

Ground control
Final disposal site plus a minimum of $0.25 \mathrm{mi}(0.4 \mathrm{~km})$ beyond site boundaries unless site conditions require otherwise.

One set of vertical color, infrared stereo contact prints, 9-in (230$\mathrm{mm}$ ), scale 1 in $=200 \mathrm{ft}(1 \mathrm{~mm}=2.4 \mathrm{~m}$ ) (representation fraction 1:2400); double weight, glossy, not trimmed.

One index map, scale $1 \mathrm{in}=200 \mathrm{ft}(1 \mathrm{~mm}=2.4 \mathrm{~m})$; flight lines and frame numbers will be provided.

One set of 2 each of low and high oblique photographs (and negatives) in natural color, 8- $\times 10$-in (200- $\times 250-\mathrm{mm})$, or 9- $\times 9$ in $(230-\times 230-\mathrm{mm})$ contact prints.

To be determined upon acceptance of this LTSP.

Precision, 9- $\times$ 9-in $(230-\times 230-\mathrm{mm})$ format for vertical photos. A 35-millimeter (single lens reflex) or larger format camera for oblique photos is acceptable.

Eastman-Kodak Aerochrome Infrared 2443, or its equivalent, for vertical photos.

Eastman-Kodak Ektacolor, or its equivalent, for oblique photos.

Wratten Nos. 12 or 15 for infrared photos. Skylight filter for color photos.

60 percent end overlap; 30 percent average side overlap.

Control stations will be second order, Class 1, for horizontal control and third order for vertical control (standard U.S.

Geological Survey map accuracy specifications). 
Each photograph will be recorded individually on a site inspection photo log (Attachment 3). An appropriate description of the feature photographed, including azimuth (if necessary), will be entered into the log. Copies of the disposal site inspection photographs and the photo log will be included in annual disposal site inspection reports.

If possible, a photograph will include a reference point such as a survey monument, boundary monument, site marker, or monitor well. For large-scale features such as drainage ditches or disposal cell slopes, a north arrow and a scale will be included for reference.

For specific areas where a photograph is used to monitor change over time, the distance from the feature and the azimuth should be recorded, and all subsequent photographs should be taken from the same orientation to provide an accurate picture of changing conditions. The magnetic declination of the compass should be corrected for true north. This information will also be provided on the inspection checklist and photo log.

All site inspection photographs taken, as well as all corresponding photo log forms, will be maintained in the permanent Falls City site file.

\section{Features to be photographed}

The following site features should be documented with photographs during every scheduled inspection at the Falls City disposal site:

- Permanent site surveillance features.

- Fences, gates, access roads, perimeter roads, and paths.

- Toe drains.

- The disposal cell (top, sides, apron, and surrounding area). Panoramic sequences of photographs from selected vantage points may be used for this purpose.

- Any evidence of erosion (e.g., gullies, rivulets, and rills) that the inspector considers significant and includes in the text of the inspection report.

- Any off-site features that may affect the site in the future and that the inspector considers significant and includes in the text.

- Vegetation (site area and disposal cell topsolope).

- Disposal cell topslope and sidesiope. 
- Erosion protection material (riprap).

- Survey control points for local coordinate system.

Any new or potential problem areas identified during a site inspection will be well documented with photographs. Photographs will also be taken to record developing trends and to allow inspectors to make reasonable decisions concerning additional inspections, custodial maintenance or repairs, or corrective action. 


\subsection{PERMANENT SITE-SURVEILLANCE FEATURES}

Survey and boundary monuments, site markers, entrance and perimeter signs, and settlement plates are the permanent surveillance features of the Falls City disposal site.

The construction and emplacement of the site surveillance features, described below, meet the specifications delineated in DOE's Guidance for Implementing the UMTRA Project Long-term Surveillance Program (DOE, 1992a).

\subsection{SURVEY MONUMENTS}

The three permanent survey monuments (SM-1, SM-2, and SM-3), Berntsen RT-1 markers, are set into the top of a reinforced and poured-in-place concrete cylinder with the dimensions shown in Figure 4.1 (Plate 2). The bottom of the concrete cylinder is a minimum of $3 \mathrm{ft}(0.9 \mathrm{~m})$ below land surface (bls). The four steel reinforcing bars permit discovery by a metal detector if the monument becomes buried over time. The three survey monuments establish permanent horizontal control based on a local coordinate system and referenced to survey control points established by the TAC.

\subsection{BOUNDARY MONUMENTS}

Two Berntsen federal aluminum survey monuments, Model A-1, were used for the boundary monuments (Figure 4.2) (Plate 2). Two corners of the disposal site are designated by Berntsen RT- 1 markers. The ceramic magnets epoxied in the cap and base of the A-1 monuments are vertically oriented for easier detection if they become buried. The boundary monuments are set with the base 36 inches $(910 \mathrm{~mm})$ bls and 12 inches $(305 \mathrm{~mm})$ above the ground surface (Figure 4.2 ).

\subsection{SITE MARKERS}

Two unpolished granite markers with the dimensions shown in Figures 4.3 and 4.4 (Plate 2) identify the Falls City disposal site, the general location of the stabilized disposal cell within the site boundaries, the date of closure (9 February 1994), the dry tonnage of tailings $(7,143,000$ tons $[6,480,000$ tonnes $]$, and the curies of radioactivity (1277 curies) of radium-226 (Ra-226) (Figure 4.5).

Site marker SMK-1 near the entrance to the site is set in a bed of reinforced concrete that extends $3 \mathrm{ft}(0.9 \mathrm{~m})$ bls (Figure 4.3). Site marker SMK-2 at the crest of the disposal cell is set in a bed of reinforced concrete that extends to the top of the radon barrier (Figure 4.4). 

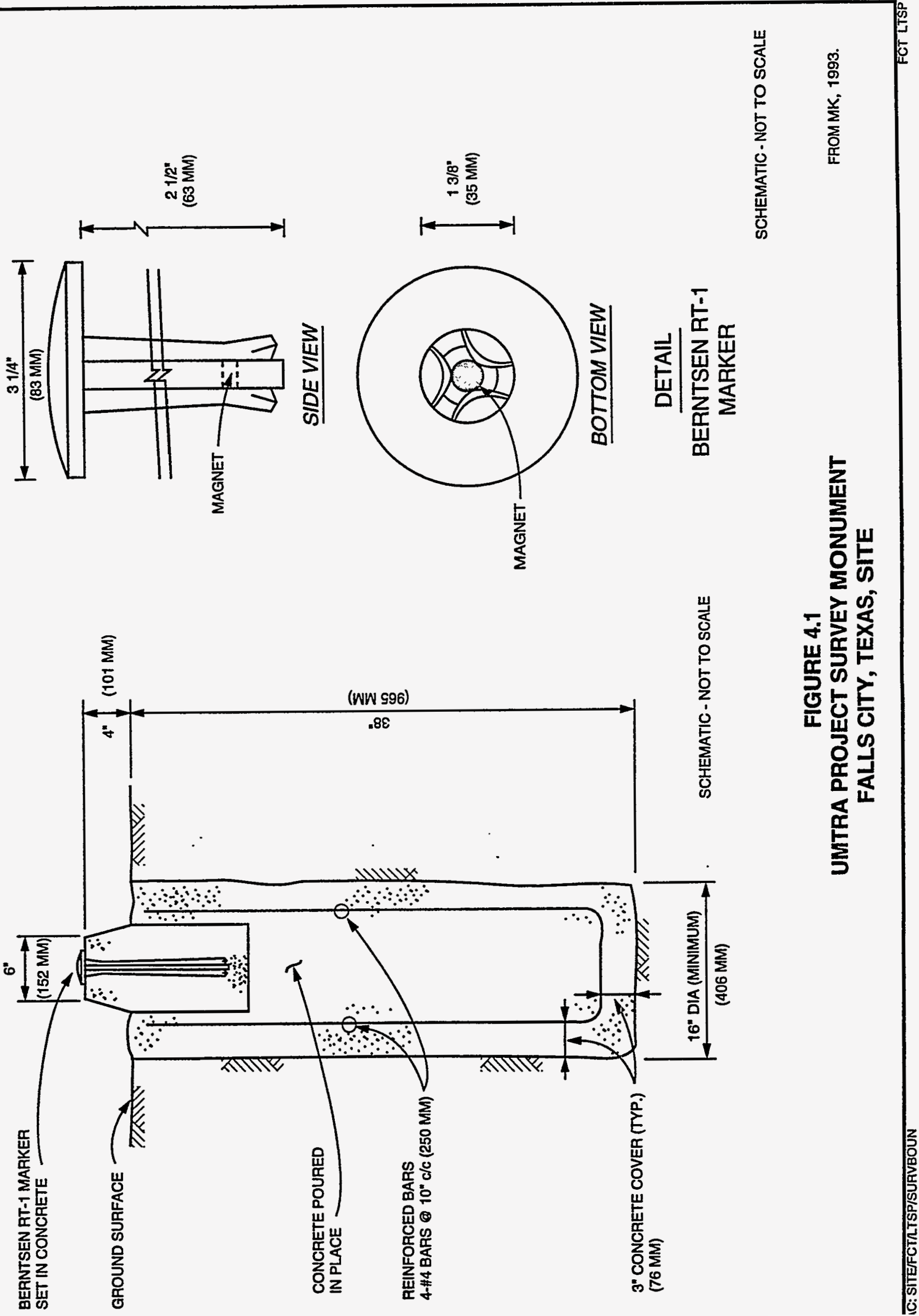


\section{BERNTSEN FEDERAL ALUMINUM BOUNDARY MONUMENT, MODEL A-1, STANDARD LOGO CAP}
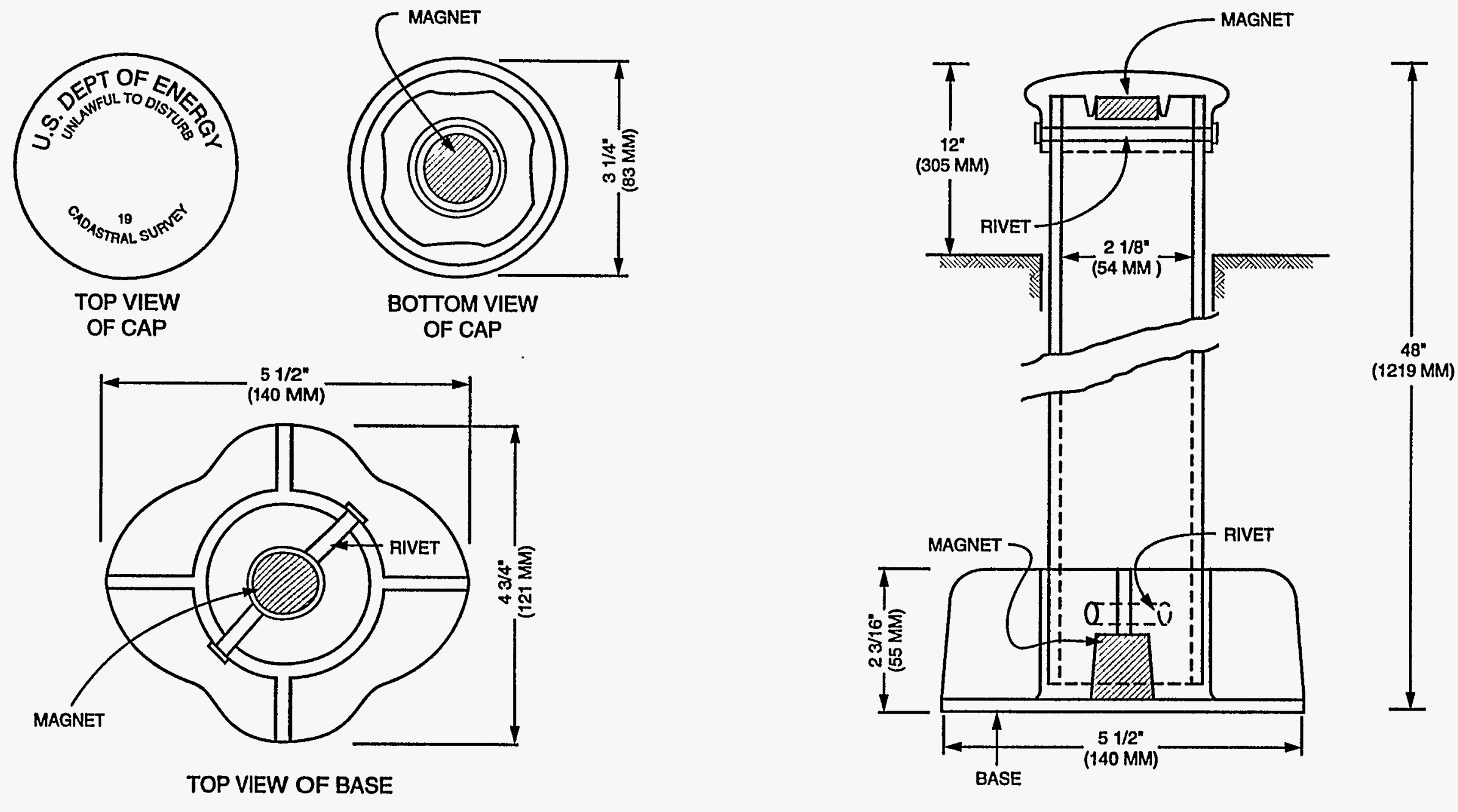

TOP VIEW OF BASE

DETAIL 


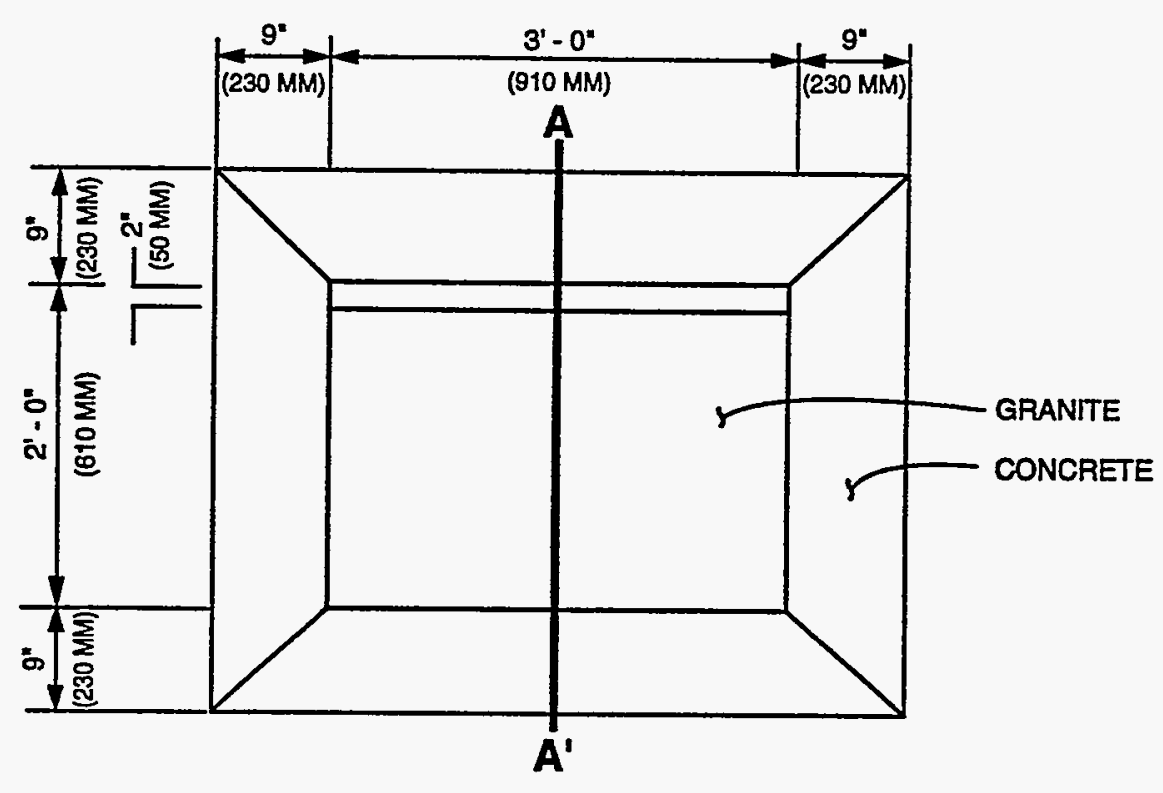

PLAN VIEW

SCHEMATIC - NOT TO SCALE

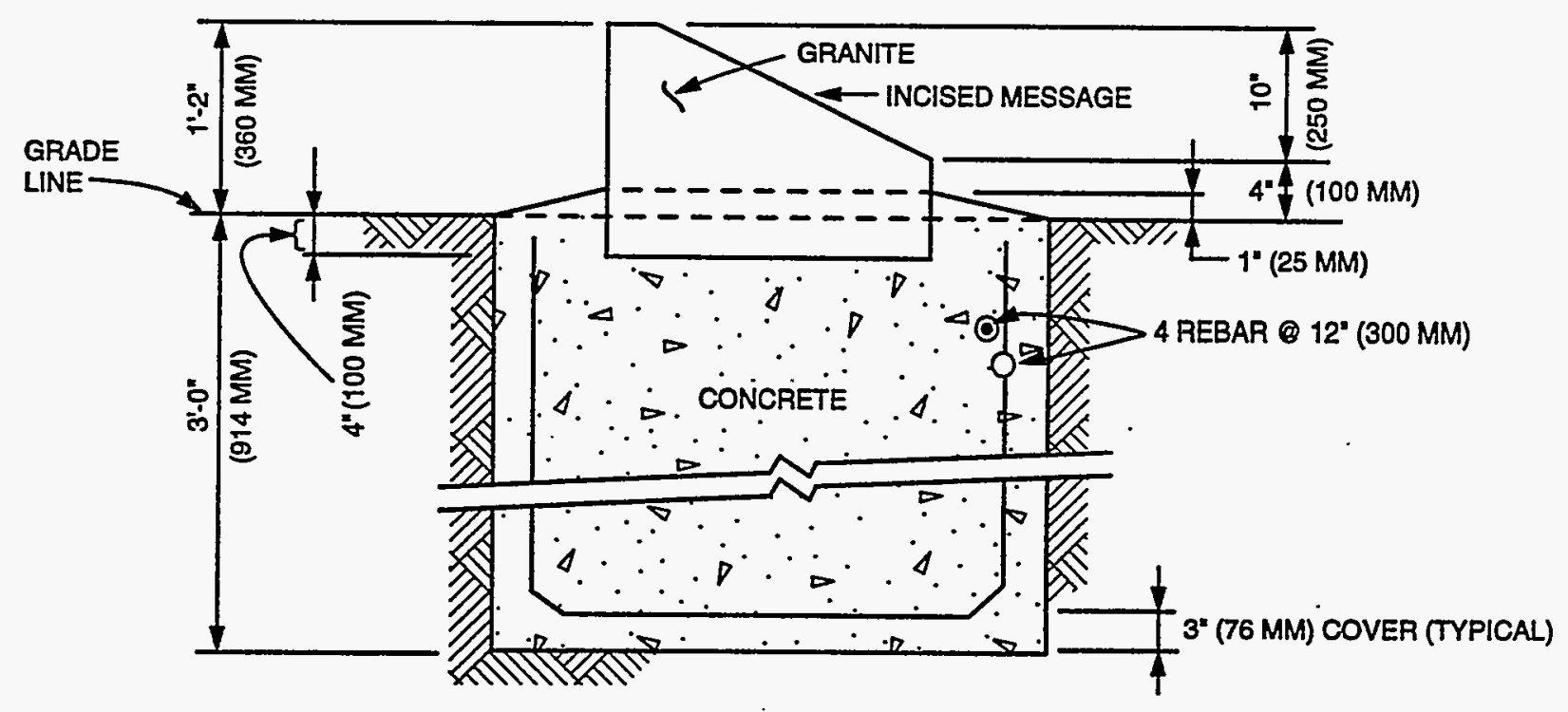

SECTION A-A'

SCHEMATIC - NOT TO SCALE

FROM MK, 1993.

FIGURE 4.3

UMTRA PROJECT SITE MARKER AT ENTRANCE OF DISPOSAL SITE FALLS CITY, TEXAS, SITE 


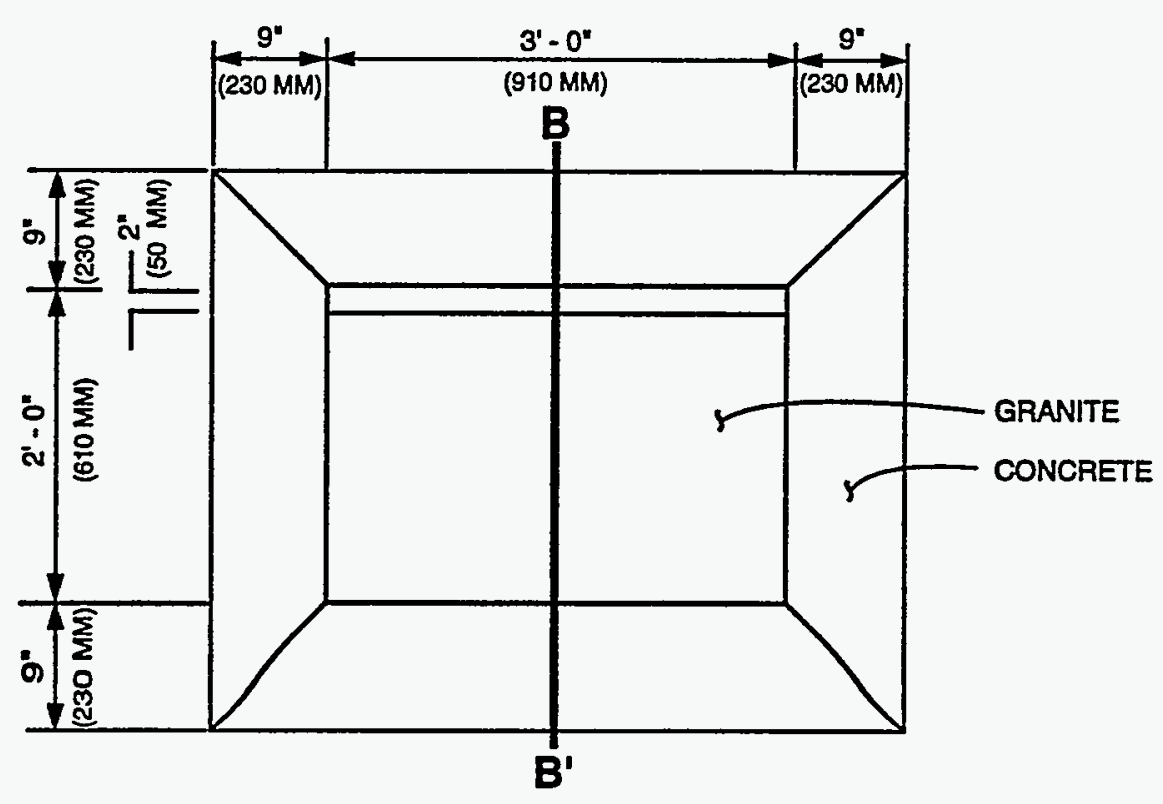

PLAN VIEW

SCHEMATIC - NOT TO SCALE

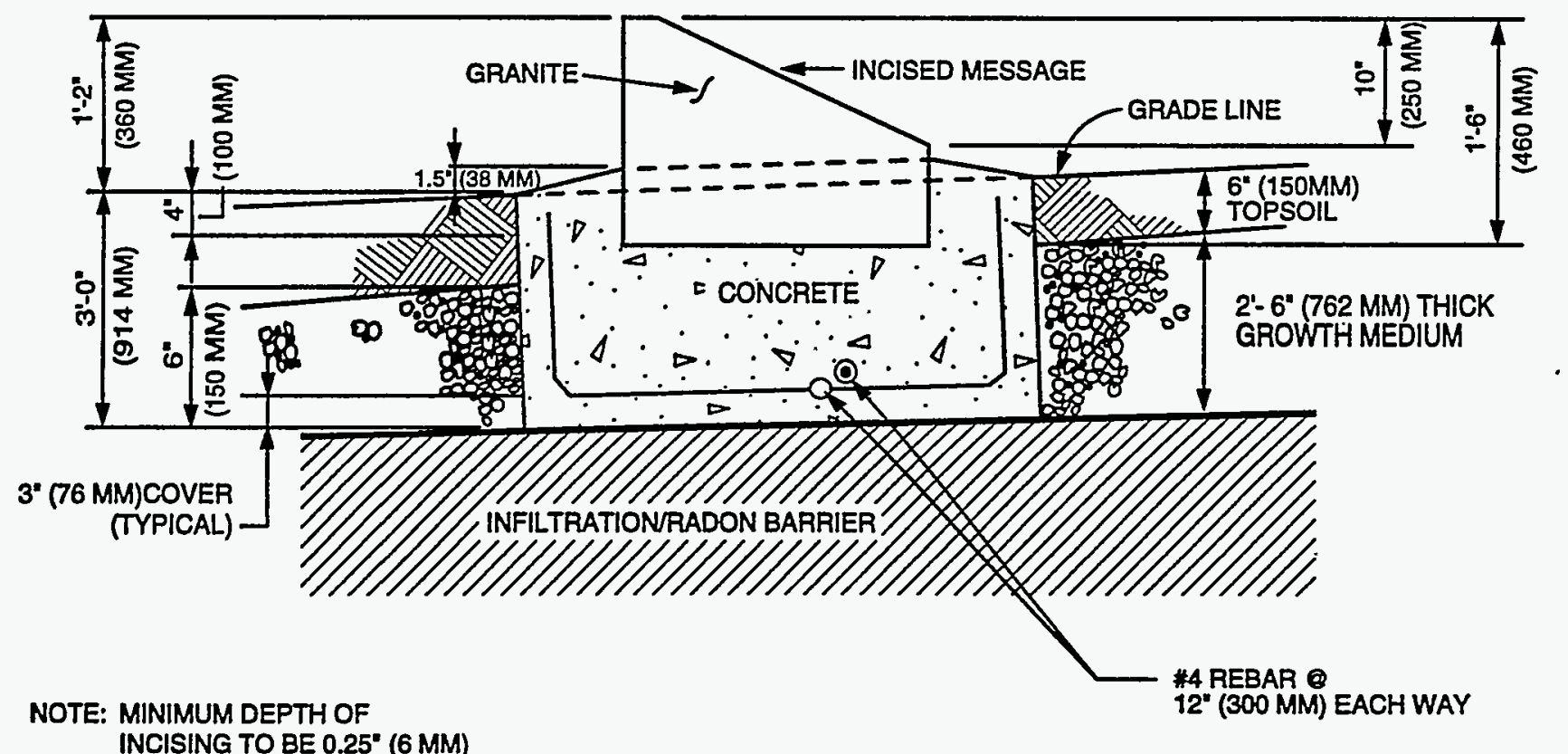

SECTION B - B'

SCHEMATIC - NOT TO SCALE

FIGURE 4.4

FROM MK, 1993.

\section{UMTRA PROJECT SITE MARKER AT CREST OF DISPOSAL CELL FALLS CITY, TEXAS, SITE}


SURVEYED REFERENCE POINT

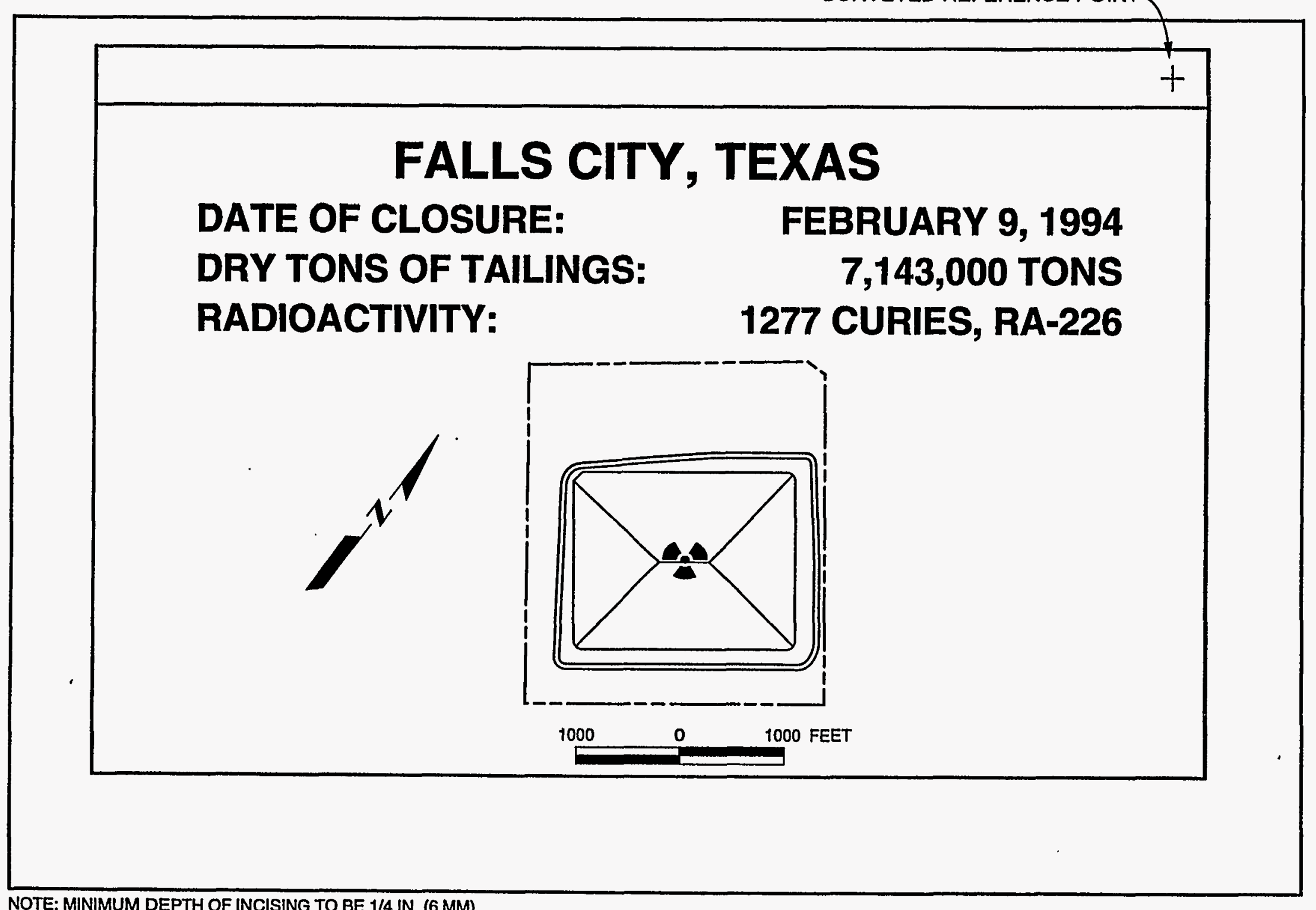

NOTE: MINIMUM DEPTH OF INCISING TO BE 1/4 IN. (6 MM).

FIGURE 4.5

FROM MK, 1993.

UMTRA PROJECT SITE MARKER INCISED MESSAGE

FALLS CITY, TEXAS, SITE 


\subsection{ENTRANCE AND PERIMETER SIGNS}

A warning sign with the following information was placed at the entrance to the disposal site: the name of the disposal site, the international symbol indicating the presence of radioactive material, a notice that trespassing is forbidden on this federally owned site, and the 24-hour telephone number of the GJPO. In addition to the entrance sign, 60 signs mounted on steel posts are placed at approximately equal intervals around the site perimeter. The perimeter signs display the international symbol indicating the presence of radioactive material and state that the disposal site is U.S. Government property, that it contains uranium mill tailings, and that trespassing is forbidden (Plate 2).

The signs are constructed in accordance with the dimensions and specifications shown in Figures 4.6 and 4.7 , mounted with the tops of the entrance and perimeter signs 70 inches $(1778 \mathrm{~mm})$ above the ground surface. The sign posts are embedded in concrete to a depth of 37 inches $(940 \mathrm{~mm})$ bls.

\subsection{SETTLEMENT PLATES}

The total long-term settlement of the disposal cell can be measured using the ten settlement plates (SP-1 through SP-10) installed before the cell was completed. Plates SP-1 through SP-10 were installed to the specifications shown in Figure 4.8 (Plate 2). Excavation of cover material was kept to a minimum during placement of the settlement plates, and any cover materials disturbed during placement were replaced following original design specifications. Settlement plates SP-1 through SP-6 were placed on slime tailings prior to placement of the radon barrier, and plates SP-7 through SP-10 were placed on the radon barrier layer after it was completed. 


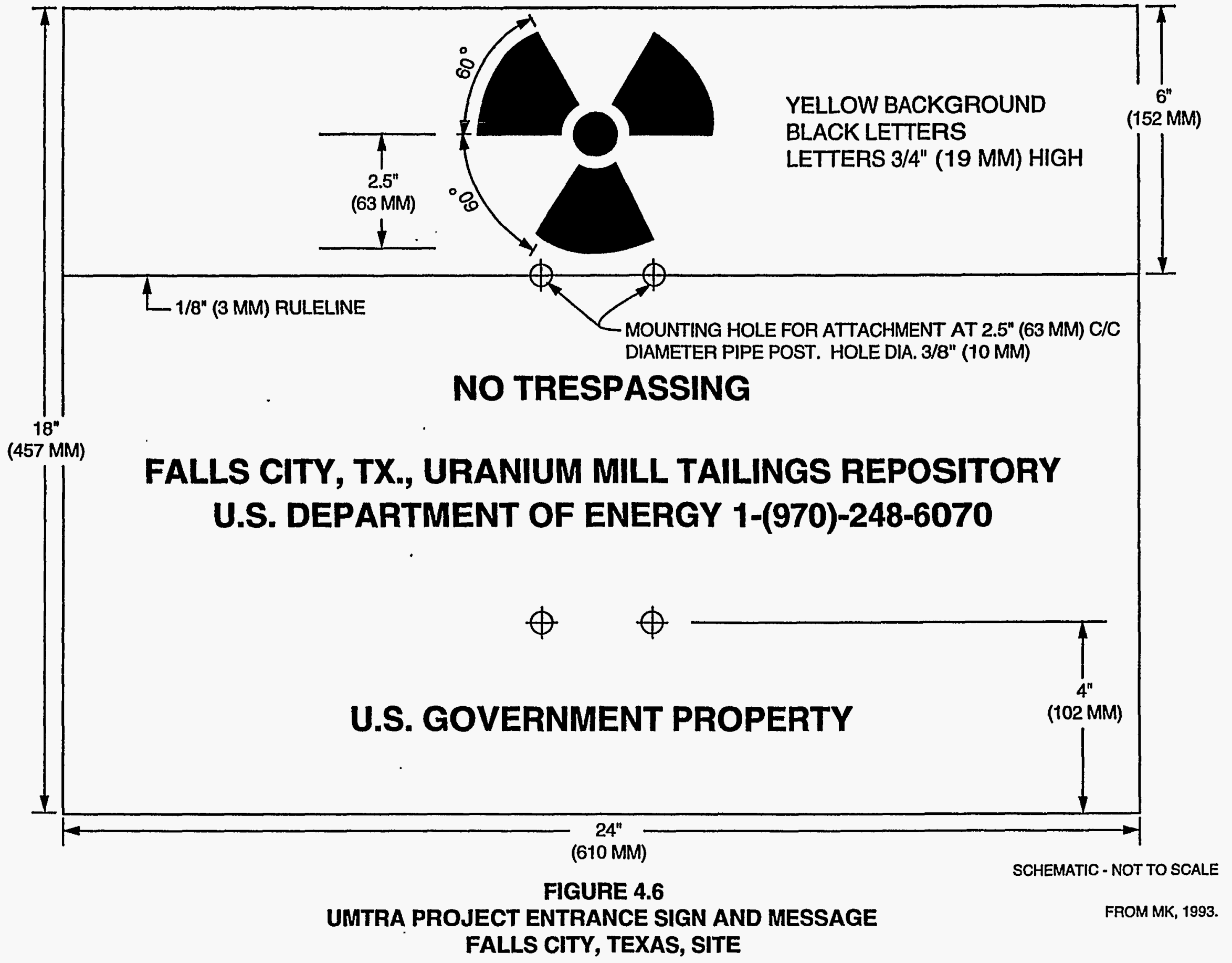




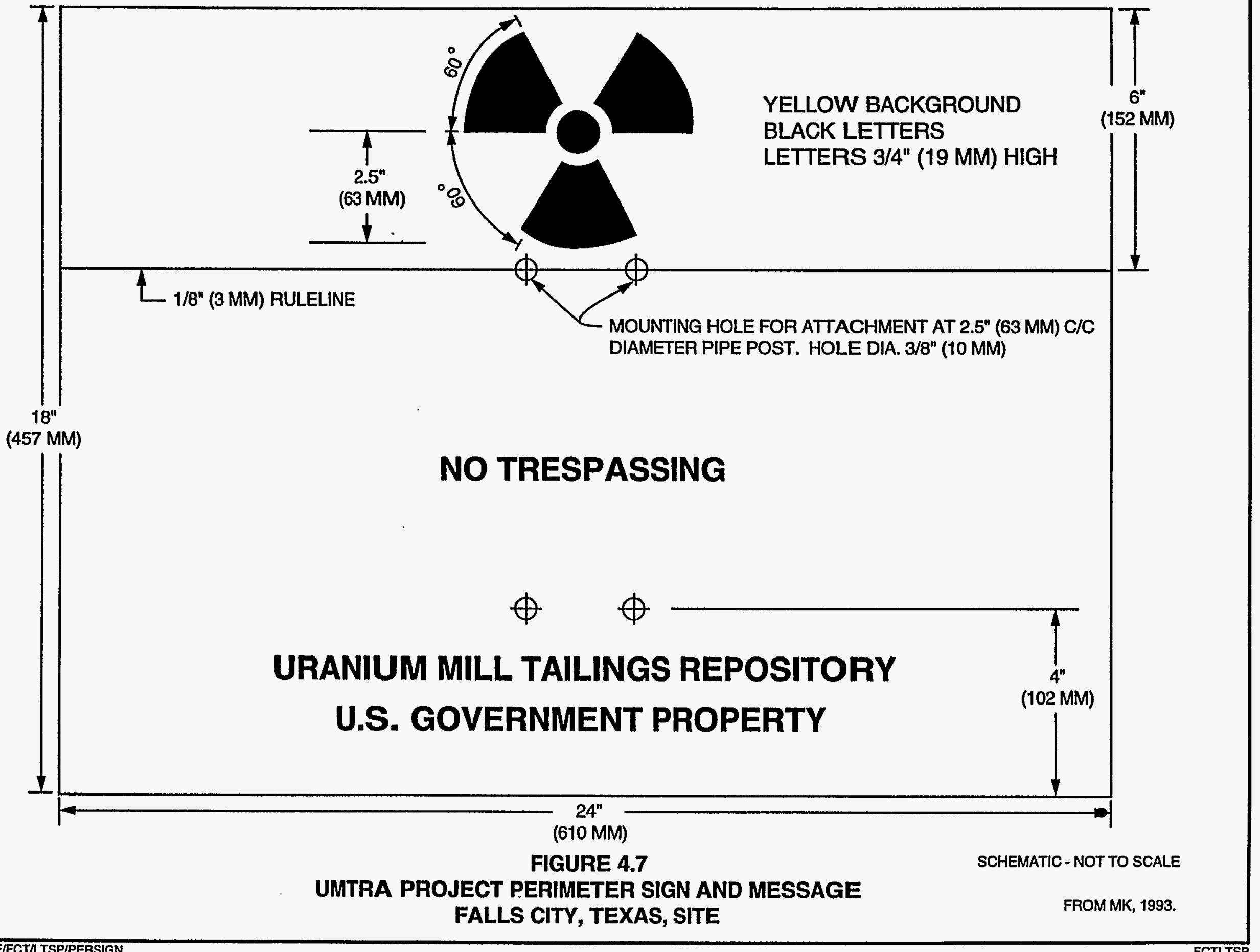




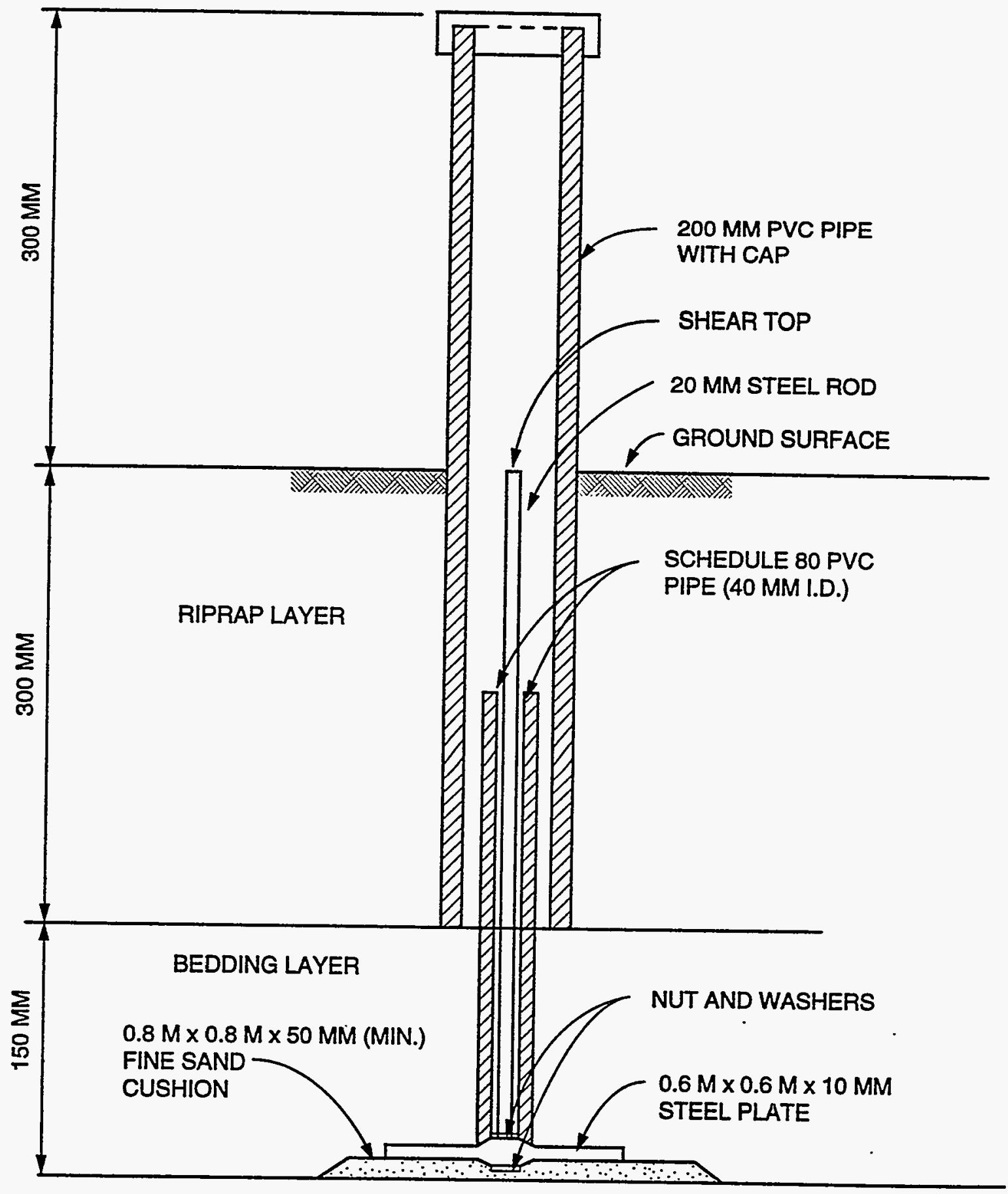

RADON BARRIER LAYER

SCHEMATIC - NOT TO SCALE

FROM MK, 1993.

FIGURE 4.8

UMTRA PROJECT SETTLEMENT PLATES

FALLS CITY, TEXAS, SITE 


\subsection{GROUND WATER MONITORING}

The need for ground water monitoring at the Falls City disposal site was evaluated in accordance with the NRC regulations in 10 CFR $\$ 40.27(\mathrm{~b})(2)$, and guidelines established by the DOE in Guidance for Implementing the UMTRA Project Long-term Surveillance Program (DOE, 1992a). Based on an evaluation of site characterization data, it has been determined that a program to monitor ground water is not required because ground water in the uppermost aquifer is of limited use (Class III), and a narrative supplemental standard has been applied to the site that does not include numerical concentration limits or a point of compliance (40 CFR 192.21(g)). The Class III designation is based on the fact that ground water in the uppermost aquifer is not currently or potentially a source of drinking water in the area because it contains widespread ambient contamination that cannot be cleaned up using methods reasonably employed by public water supply systems. Background water quality varies by orders of magnitude in the area since the aquifer is in an area of redistribution of uranium mineralization derived from ore bodies.

However, as a best management practice and to alleviate concerns expressed by the state of Texas over the demonstration of disposal cell effectiveness, a ground water monitoring program will be implemented. The purpose of the program is to evaluate disposal cell performance by monitoring for changes in ground water quality over the initial ambient conditions. The monitoring is anticipated to cover a 5-year period following completion of the disposal cell construction. At the end of that period of time (in 1999), termination of ground water monitoring will be anticipated.

\subsection{GROUND WATER CHARACTERIZATION}

The DOE's characterization of the hydrogeologic units, aquifer hydraulic and transport properties, tailings materials, and geochemical conditions at the Falls City disposal site (presented in detail in the Falls City RAP [DOE, 1992b]) is summarized below.

\subsubsection{Hydrostratigraphy}

The Falls City site is underlain by clastic sedimentary strata that dip gently southeast (approximately $20 \mathrm{ft}$ per $1000 \mathrm{ft}$ [slope $=0.02$ ]) as part of the thick homoclinal sequence of the Gulf Coastal Plain. The local sedimentary strata are comprised of generally unlithified sand, silt, and clay deposits of the Whitsett and Manning Clay Formations. The site rests on outcrops of the Dubose Clay, Deweesville Sandstone, and Conquista Clay Members of the Whitsett Formation (Figure 5.1).

Three low-yield water-bearing strata are within the upper $200 \mathrm{ft}(60 \mathrm{~m})$ of the Whitsett Formation sediments underlying the site: 1) the Deweesville Sandstone Member, 2) the Conquista Clay Member, and 3) the Dilworth Sandstone Member. The Conquista Clay Member is composed of three subunits: an oxidized upper Conquista Clay/silt, the Conquista Sandstone, and a lower Conquista Clay (Figure 5.2). The Conquista Sandstone extends downdip into the subsurface, but thins significantly and becomes considerably finer grained. The Deweesville Sandstone 


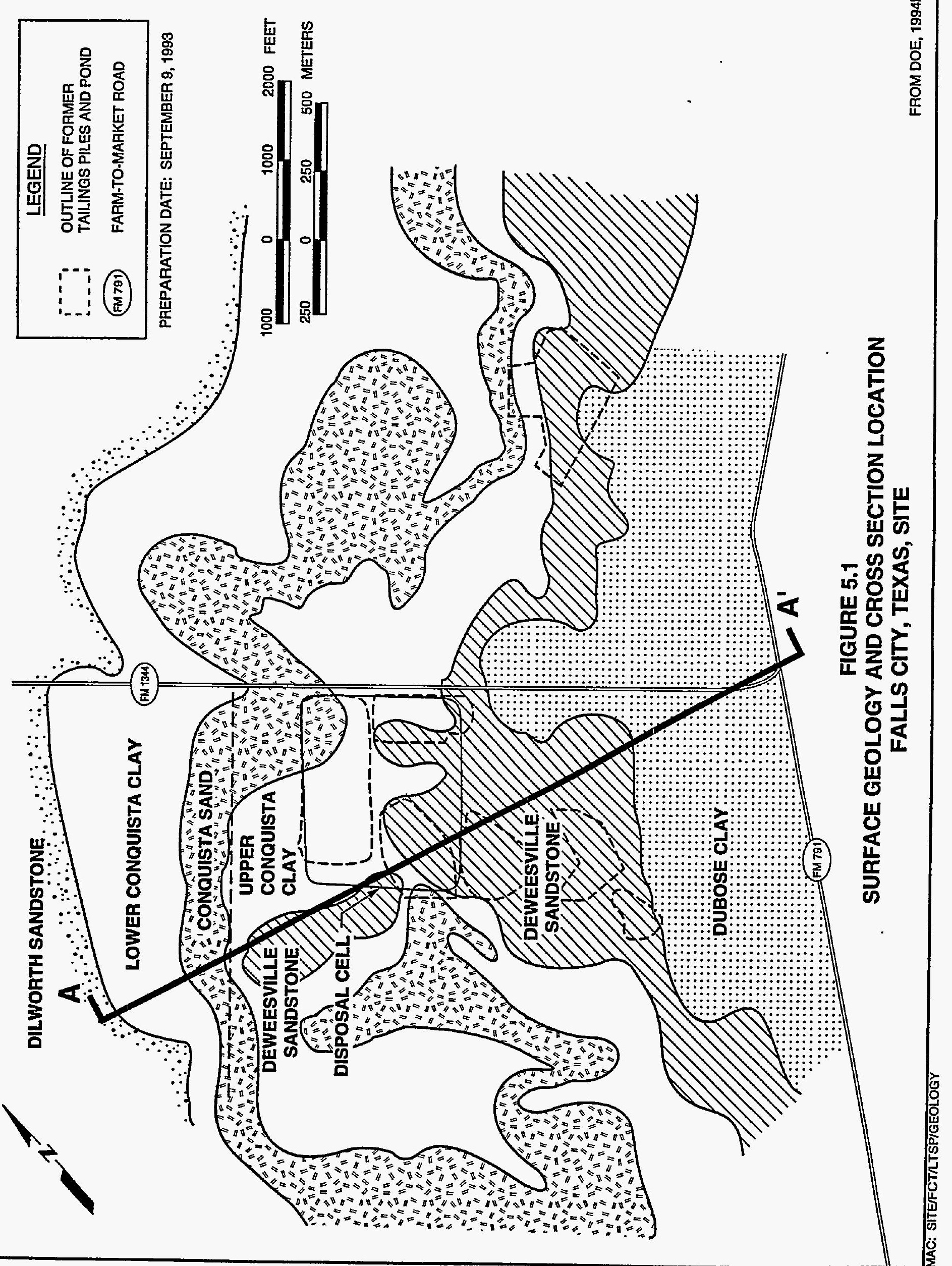




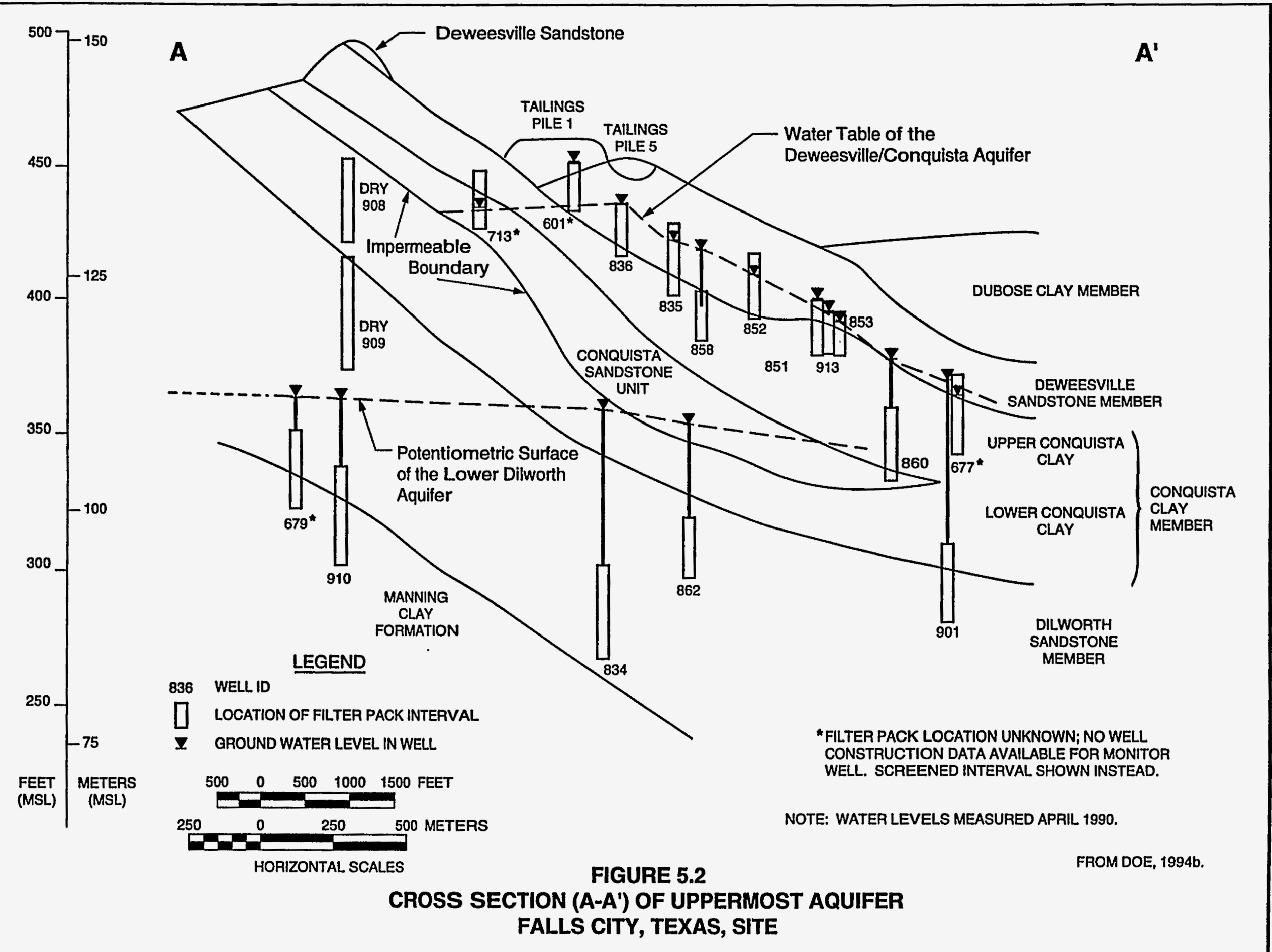


Member, upper Conquista Clay, and Conquista Sandstone subunits are grouped together as one aquifer, referred to as the Deweesville/Conquista aquifer, because impermeable strata do not separate the members.

\section{Deweesville/Conquista aquifer}

Shallow ground water in the site vicinity is found in the Deweesville/Conquista aquifer at depths of 5 to $30 \mathrm{ft}(2$ to $9 \mathrm{~m})$ bls. Ground water within the aquiferoccurs under unconfined conditions in the northern and western portions of the site vicinity and along creek beds. In areas where the Deweesville/Conquista aquifer is unconfined, the potentiometric surface generally is a subdued replica of the surface topography.

The top of the lower Conquista Clay defines the lower boundary of the Deweesville/Conquista aquifer. The intersection of the Deweesville/Conquista water table and the top of the lower Conquista Clay marks the updip limit of saturation in the Deweesville/Conquista aquifer (Figure 5.2). Two wells were completed updip of this intersection, and consequently, are dry. Because the tailings piles overlied outcrops of the Deweesvilie Sandstone and the upper Conquista Clay at the surface, it is impossible to install upgradient, background monitor wells screened in the Deweesville/Conquista aquifer.

Ground water within the Deweesville/Conquista aquifer is recharged by infiltrating precipitation in the Deweesville/Conquista outcrop areas, seepage of tailings fluids, and interformation leakage in downdip areas. Ground water within the Deweesville/Conquista aquifer, immediately downgradient of the disposal cell, discharges to the eastern tributary of Tordilla Creek, and might continue downdip into the subsurface where some ground water might discharge into Conquista Creek, southeast of FM 791. North of former tailings pile 3, ground water flows locally to the north toward Scared Dog Creek.

The horizontal hydraulic conductivities in the Deweesville and Conquista units are highly variable, with a value range of two orders of magnitude. The maximum horizontal hydraulic conductivity for the Deweesville/Conquista aquifer is $2.6 \mathrm{ft}$ per day $\left(9.2 \times 10^{-4} \mathrm{~cm} / \mathrm{s}\right)$ and is calculated from aquifer test data from a well screened in the Conquista Sandstone (DOE, 1992b). Using Darcy's Law, an assumed effective porosity of 0.1 , and an average hydraulic gradient of 0.013 to the east-southeast, the maximum average linear ground water velocity is $130 \mathrm{ft}(40 \mathrm{~m})$ per year.

\section{Dilworth aquifer}

The Dilworth aquifer is a sandstone member of the Whitsett Formation. It is separated from the Deweesville/Conquista aquifer by 30 to $50 \mathrm{ft}(9$ to $15 \mathrm{~m}$ ) of carbonaceous clay of the lower Conquista Clay subunit, which acts as an aquitard to downward seepage. The Dilworth aquifer is approximately $100 \mathrm{ft}(30 \mathrm{~m})$ thick below the disposal cell.

Near the outcrop of the Dilworth sandstone (Figure 5.1), ground water is unconfined. Depths to ground water in the Dilworth aquifer range from 
approximately 30 to $100 \mathrm{ft}(9$ to $30 \mathrm{~m}$ ) bls. Downdip to the southeast, ground water in the Dilworth aquifer becomes confined by the lower Conquista clay. A crosssectional view of the potentiometric surface of the Dilworth aquifer is shown in Figure 5.2.

Because there is a potential hydraulic interconnection between the Deweesville/Conquista aquifer and the Dilworth unit by improperly abandoned exploratory boreholes, the Dilworth unit is included as part of the uppermost aquifer.

Average linear ground water velocities in the Dilworth aquifer were calculated using a hydraulic conductivity of $0.68 \mathrm{ft}$ per day $\left(2.4 \times 10^{-4} \mathrm{~cm} / \mathrm{s}\right.$ ) (approximate maximum value from aquifer tests), a hydraulic gradient of 0.009 to the east-southeast, and an assumed effective porosity of 0.1 for the fine sands of this zone (DOE, 1992b). The average linear velocity for ground water flow in the lower Dilworth aquifer is approximately $22 \mathrm{ft}(6.7 \mathrm{~m})$ per year.

\subsubsection{Background ground water quality}

Background ground water quality for the Deweesville/Conquista and Dilworth aquifers is defined as the quality of ground water at the Falls City site that would be present if uranium processing activities had not occurred.

There is no single background ground water quality for each of these aquifers. The natural ground water quality varies within these aquifers as a function of residence time and aquifer matrix composition. The Deweesville/Conquista and Dilworth aquifers can each be separated into three general regions or zones with different mineralogical and compositional characteristics. These zones are defined as the oxidized, transitional, and reduced zones. Although these zones overlap, the ground water in each zone typically is distinct in composition from the ground water in the other zones. This is especially true of metals. For example, iron and manganese occur at greater concentrations in the reduced zones, while uranium occurs at greater concentrations in the oxidized zone. Table 5.1 summarizes the range of background ground water quality in each of these zones at the site. The composition of a typical tailings pore fluid is provided for comparison.

Other water quality data are presented in the Falls City RAP (DOE, 1992b). The numerous unmined and mined ore bodies in the oxidized, transitional, and reduced zones of the regional sediments and variations in geochemical conditions cause considerable variation in the natural concentrations of hazardous trace constituents including uranium (Table 5.1).

\section{Deweesville/Conquista}

The oxidized zone of the Deweesville/Conquista aquifer is defined as the outcrop area and shallow subsurface. At the Falls City site, this zone was largely unsaturated before mining and milling. The oxidized zone later became saturated by the influx of large volumes of tailings leachate and mill processing water. Thus, 
Table 5.1 Typical water quality data for Dilworth and Deweesville/Conquista background wells

\begin{tabular}{|c|c|c|c|c|c|c|c|c|}
\hline \multirow[t]{2}{*}{ Constituents } & \multirow{2}{*}{$\begin{array}{c}\begin{array}{c}\text { Tailings } \\
\text { fluid" }^{\mathrm{a}}\end{array} \\
607\end{array}$} & \multicolumn{2}{|c|}{ Reduced zone } & \multicolumn{2}{|c|}{ Transitional zone } & \multicolumn{3}{|c|}{ Oxidized zone (outcrop area) } \\
\hline & & 667 & 668 & 951 & 969 & 967 & 968 & 979 \\
\hline Alkalinity ${ }^{b}$ & NA & 252 & 250 & 307 & 291 & 116 & 226 & 193 \\
\hline Calcium & 494 & 335 & 405 & 364 & 495 & 278 & 90 & 258 \\
\hline Chloride & 1210 & 785 & 944 & 708 & 779 & 793 & 338 & 672 \\
\hline Iron & 430 & 0.45 & 0.19 & 0.03 & 0.87 & $<0.03$ & $<0.03$ & $<0.03$ \\
\hline Magnesium & 185 & 31.8 & 45.1 & 29 & 61 & 30.5 & 8.1 & 28.3 \\
\hline Manganese & 21.8 & 0.21 & 0.78 & 0.21 & 2.94 & 0.02 & $<0.01$ & 0.07 \\
\hline Nitrate & 0.5 & 4.9 & 3.5 & 4 & 1.3 & 10.2 & 12.4 & 4.4 \\
\hline pH & 2.95 & 6.65 & 6.63 & 6.75 & 6.70 & 5.98 & 6.58 & 6.08 \\
\hline Potassium & 1.77 & 43 & 29 & 45 & 43 & 30 & 18 & 36 \\
\hline Sodium & 739 & 678 & 583 & 652 & 550 & 675 & 121 & 531 \\
\hline Sulfate & 7700 & 1043 & 930 & 856 & 1290 & 817 & 156 & 569 \\
\hline Total dissolved solids & 12900 & 3120 & 3310 & 2291 & 3650 & 2750 & 624 & 2210 \\
\hline Uranium & 1.19 & 0.015 & 0.017 & 0.008 & 0.010 & 0.003 & 0.068 & 0.25 \\
\hline
\end{tabular}

"Water quality data from January 1991.

$\mathrm{mg} / \mathrm{L} \mathrm{CaCO}{ }_{3}$.

Notes:

1. Water quality data from June 1991 and July 1991 from Dilworth background wells 967, 968, 969, and 979;

and Deweesville/Conquista background wells 951,667, and 668, except where noted (Figure 5.3).

2. Concentrations are reported in milligrams per liter (mg/L) except for $\mathrm{pH}$.

NA - Not analyzed. 
ground water in this zone at the mill site is not the result of natural processes. Therefore, a background ground water quality for the oxidized, outcrop zone of the Deweesville/Conquista aquifer does not exist in the mill site area.The transitional zone begins at the downdip edge of the Deweesville/Conquista outcrop (where the sediments are dominantly oxidized) and ends at about the location of FM-791 (where the sediments are dominantly reduced). Ground water quality before mining and milling activities in the uranium mineralized zone might have been similar to that found in monitor well 951 or monitor well 969 (Table 5.1 and Figure 5.3).

The upgradient limit of the reduced zone for the Deweesville/Conquista outcrop was identified by the DOE and Texas Bureau of Economic Geology as being at the downgradient edge of the DOE monitor well array (beginning at FM-791). Ground water quality data from Conoco monitor wells 667 and 668 suggest the ground water quality of the Deweesville/Conquista in parts of this reduced zone is higher in iron and manganese and perhaps sulfate, chloride, and other constituents than water from the oxidized zone. Figure 5.4 shows the locations of the Conoco monitor wells (667 and 668) and Dilworth background monitor wells.

To expand the background water quality database for the Deweesville/Conquista aquifer, ground water quality data from other areas in the Deweesville/Conquista were evaluated. Thity-nine monitor wells were completed in the Deweesville Sandstone before mining activities began at the Hobson in situ uranium mine site, about $7 \mathrm{mi}$ (about $11 \mathrm{~km}$ ) east of the Falls City site. Of those 39 wells, 28 were completed in the Deweesville Sandstone ore body and the remaining 11 were completed nearby. Table 5.2 presents a statistical summary of data obtained from the Deweesville monitor wells, including background and site-contaminated ground water quality data. The Deweesville wells at the Hobson site are generally screened between 300 and $450 \mathrm{ft}(90$ to $140 \mathrm{~m}$ ) bls. Therefore, ground water from the Hobson site has probably migrated farther into the reduced zone of this aquifer than ground water from monitor wells 667 and 668 . There are lower concentrations of sulfate, chloride, and other major and minor constituents in the Hobson ground water relative to the 600 series. wells (Table 5.2).

Unlike major and minor element data, the trace element data from the Hobson area ground water differ from those of monitor wells 667 and 668. By contrast, the Hobson data show significantly elevated levels of lead, radium-226, and uranium (Table 5.2), because most of the Hobson samples were Deweesville ground water that is equilibrating with uranium ore. These data demonstrate the natural variation in Deweesville/Conquista water quality throughout the region due, in part, to the presence or absence of uranium mineralization.

\section{Dilworth}

Four upgradient Dilworth monitor wells $(967,968,969$, and 979) were used to delineate the background water quality of this aquifer at the Falls City site. Table 5.3 presents a statistical summary of the water quality of the Dilworth background ground water. 


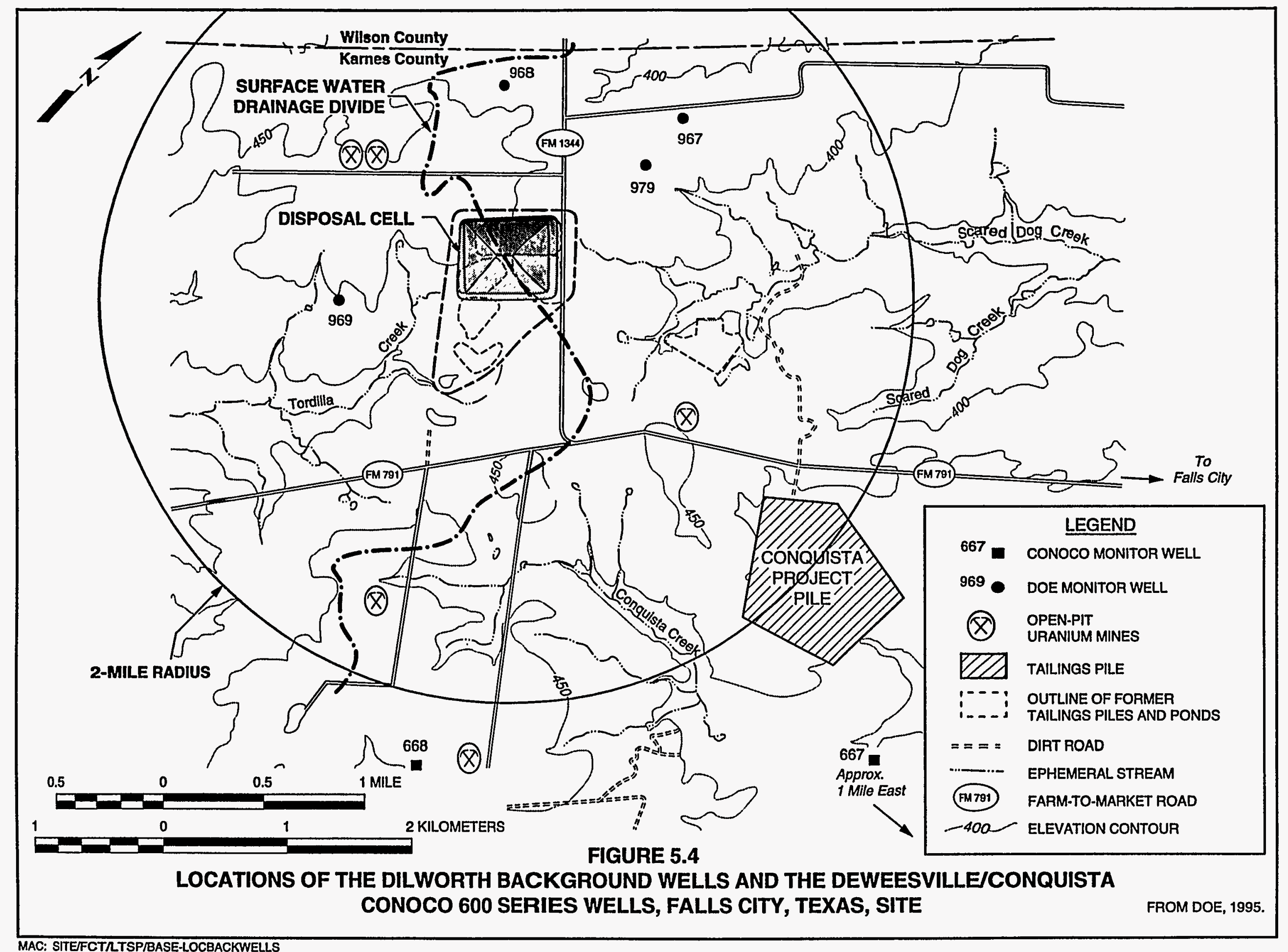




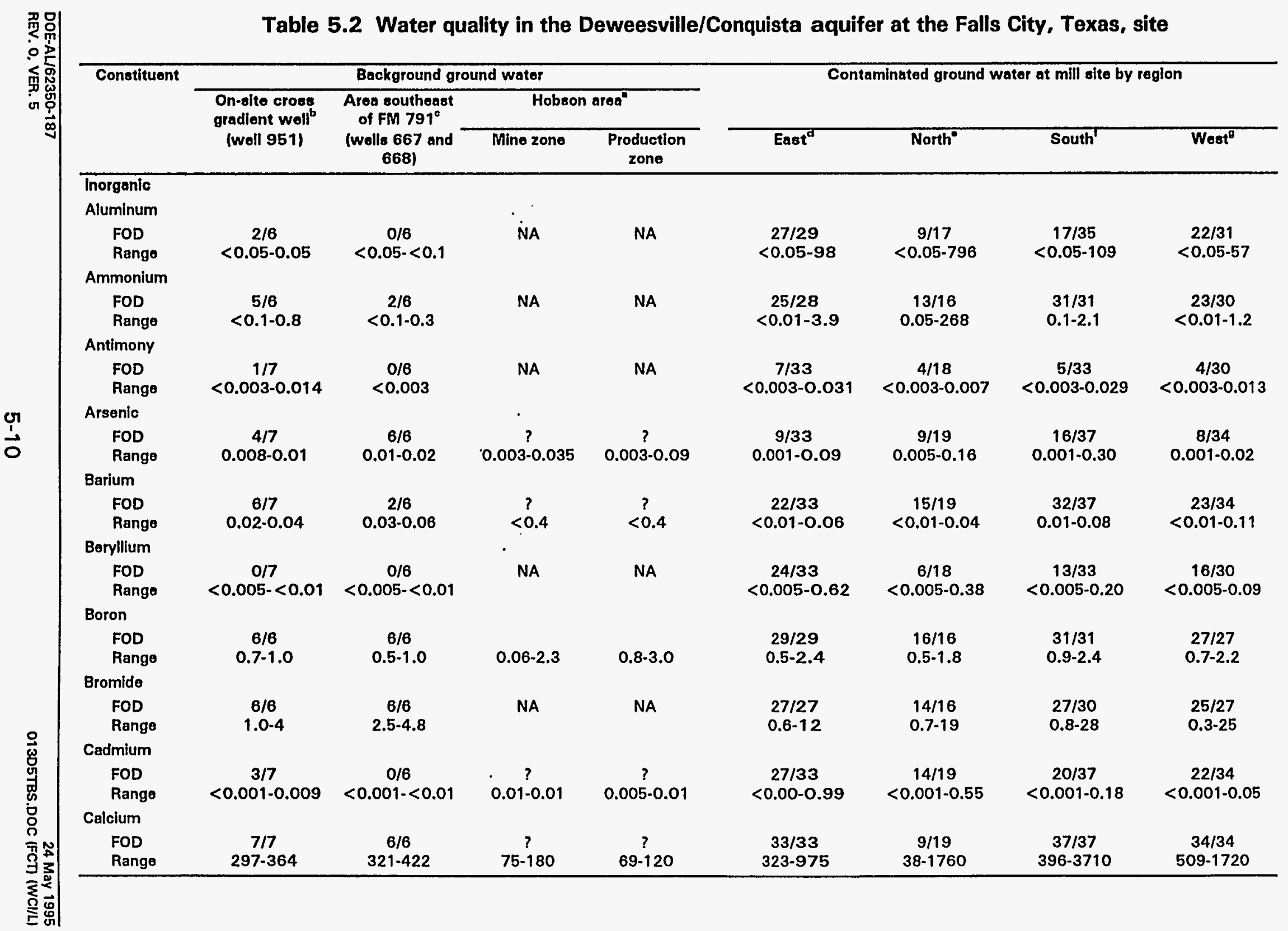




\begin{tabular}{|c|c|c|c|c|c|c|c|c|c|}
\hline \multirow{4}{*}{ 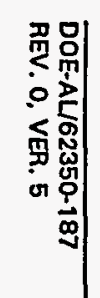 } & \multicolumn{9}{|c|}{ Table 5.2 Water quality in the Deweesville/Conquista aquifer at the Falls City, Texas, site (Continued) } \\
\hline & \multirow[t]{3}{*}{ Constituent } & \multicolumn{4}{|c|}{ Background ground water } & \multicolumn{4}{|c|}{ Contaminated ground water at mill sito by region } \\
\hline & & \multirow{2}{*}{$\begin{array}{l}\text { On-site cross } \\
\text { gradient woilb } \\
\text { (well 951) }\end{array}$} & \multirow{2}{*}{$\begin{array}{c}\text { Area southeast } \\
\text { of FM } 791^{\circ} \\
\text { (wells } 667 \text { and } \\
668 \text { ) }\end{array}$} & \multicolumn{2}{|c|}{ Hobson arog" } & \multirow[b]{2}{*}{ East $^{d}$} & \multirow[b]{2}{*}{ North } & \multirow[b]{2}{*}{ South' } & \multirow[b]{2}{*}{ West $^{0}$} \\
\hline & & & & Mine zone & $\begin{array}{l}\text { Production } \\
\text { zono }\end{array}$ & & & & \\
\hline \multirow{16}{*}{$\stackrel{g}{\grave{I}}$} & Chloride & & & & & & & & \\
\hline & $\begin{array}{l}\text { FOD } \\
\text { Rango }\end{array}$ & $\begin{array}{c}7 / 7 \\
708-780\end{array}$ & $\begin{array}{c}6 / 6 \\
785-1090\end{array}$ & $\stackrel{?}{3.79-600}$ & $\begin{array}{c}? \\
264-542\end{array}$ & $\begin{array}{c}31 / 31 \\
621-2460\end{array}$ & $\begin{array}{c}19 / 19 \\
558-3800\end{array}$ & $\begin{array}{c}36 / 36 \\
680-7480\end{array}$ & $\begin{array}{c}34 / 34 \\
173-6820\end{array}$ \\
\hline & Chromium & & & & & & & & \\
\hline & $\begin{array}{l}\text { FOD } \\
\text { Range }\end{array}$ & $\begin{array}{c}1 / 7 \\
<0.01 \cdot 0.01\end{array}$ & $\begin{array}{c}0 / 6 \\
<0.01\end{array}$ & $\begin{array}{c}? \\
<0.01-0.1\end{array}$ & $\begin{array}{c}? \\
<0.01-0.1\end{array}$ & $\begin{array}{c}3 / 33 \\
<0.01-0.01\end{array}$ & $\begin{array}{c}5 / 19 \\
<0.01-0.03\end{array}$ & $\begin{array}{c}3 / 37 \\
<0.01 \cdot 0.02\end{array}$ & $\begin{array}{c}4 / 34 \\
<0.01-0.03\end{array}$ \\
\hline & Cobalt & & & & & & & & \\
\hline & $\begin{array}{l}\text { FOD } \\
\text { Range }\end{array}$ & $\begin{array}{c}1 / 7 \\
0.01\end{array}$ & $\begin{array}{c}0 / 6 \\
<0.03-<0.05\end{array}$ & NA & NA & $\begin{array}{c}31 / 33 \\
<0.03-1.2\end{array}$ & $\begin{array}{c}6 / 18 \\
0.01-0.7\end{array}$ & $\begin{array}{c}15 / 18 \\
0.01-0.6\end{array}$ & $\begin{array}{c}19 / 30 \\
0.01-0.3\end{array}$ \\
\hline & Copper & & & & & & & & \\
\hline & $\begin{array}{l}\text { FOD } \\
\text { Rango }\end{array}$ & $\begin{array}{c}1 / 7 \\
<0.01-0.03\end{array}$ & $\begin{array}{c}0 / 6 \\
<0.01-<0.02\end{array}$ & $\frac{?}{0.01-0.2}$ & $\begin{array}{c}? \\
<0.01-0.5\end{array}$ & $\begin{array}{c}13 / 33 \\
<0.01 \cdot 0.25\end{array}$ & $\begin{array}{c}9 / 18 \\
<0.01-0.12\end{array}$ & $\begin{array}{c}14 / 33 \\
<0.01-0.07\end{array}$ & $\begin{array}{c}14 / 30 \\
<0.01-0.11\end{array}$ \\
\hline & Cyanido & & & & & & & & \\
\hline & $\begin{array}{l}\text { FOD } \\
\text { Rango }\end{array}$ & $\begin{array}{c}0 / 5 \\
<0.01-<0.02\end{array}$ & $\begin{array}{c}0 / 6 \\
<0.01\end{array}$ & NA & NA & $\begin{array}{c}1 / 24 \\
<0.01-0.01\end{array}$ & $\begin{array}{c}1 / 12 \\
<0.01-0.02\end{array}$ & $\begin{array}{c}0 / 18 \\
<0.01-<0.02\end{array}$ & $\begin{array}{c}2 / 19 \\
<0.01-0.02\end{array}$ \\
\hline & Fluoride & & & & & & & & \\
\hline & $\begin{array}{l}\text { FOD } \\
\text { Renge }\end{array}$ & $\begin{array}{c}6 / 6 \\
0.2-0.8\end{array}$ & $\begin{array}{c}6 / 6 \\
0.6 \cdot 0.7\end{array}$ & $\stackrel{?}{0.1-2}$ & $\stackrel{?}{?} 0.04-0.4$ & $\begin{array}{c}26 / 28 \\
<0.1-4.3\end{array}$ & $\begin{array}{c}15 / 16 \\
<0.1-43\end{array}$ & $\begin{array}{l}26 / 30 \\
<0.1-12\end{array}$ & $\begin{array}{l}24 / 27 \\
<0.1-4\end{array}$ \\
\hline & Iron & & & & & & & & \\
\hline & $\begin{array}{l}\text { FOD } \\
\text { Rango }\end{array}$ & $\begin{array}{c}4 / 7 \\
0.02-0.06\end{array}$ & $\begin{array}{c}5 / 6 \\
<0.03-0.45\end{array}$ & $\begin{array}{l}? \\
0.06-2.3\end{array}$ & $\begin{array}{c}? \\
0.07-5.8\end{array}$ & $\begin{array}{c}29 / 33 \\
<0.03-126\end{array}$ & $\begin{array}{c}11 / 19 \\
0.02-458\end{array}$ & $\begin{array}{c}33 / 37 \\
0.02-49\end{array}$ & $\begin{array}{c}19 / 34 \\
0.02-77\end{array}$ \\
\hline & Load & & & & & & & & \\
\hline & $\begin{array}{c}\text { FOD } \\
\text { Pango } \\
\text { Magnesium }\end{array}$ & $\begin{array}{c}1 / 7 \\
0.001\end{array}$ & $\begin{array}{c}0 / 6 \\
<0.005-<0.01\end{array}$ & 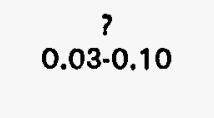 & $\stackrel{?}{0.02-0.15}$ & $\begin{array}{c}9 / 33 \\
0.001-0.04\end{array}$ & $\begin{array}{c}4 / 19 \\
0.001-0.02\end{array}$ & $\begin{array}{c}8 / 37 \\
<0.001-0.03\end{array}$ & $\begin{array}{c}7 / 34 \\
0.001-0.02\end{array}$ \\
\hline \multirow{4}{*}{ 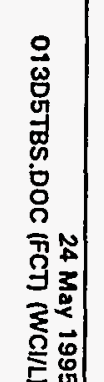 } & $\begin{array}{l}\text { FOD } \\
\text { Range }\end{array}$ & $\begin{array}{c}7 / 7 \\
26-33\end{array}$ & $\begin{array}{c}6 / 6 \\
32-51\end{array}$ & $\stackrel{?}{0.3-9.4}$ & $\stackrel{?}{1.8-4.2}$ & $\begin{array}{c}33 / 33 \\
36-574\end{array}$ & $\begin{array}{c}19 / 19 \\
5-1050\end{array}$ & $\begin{array}{c}37 / 87 \\
44-752\end{array}$ & $\begin{array}{c}34 / 34 \\
81-381\end{array}$ \\
\hline & $\begin{array}{l}\text { FOD } \\
\text { Range }\end{array}$ & $\begin{array}{c}7 / 7 \\
0.04-0.6\end{array}$ & $\begin{array}{c}6 / 8 \\
0.2-0.8\end{array}$ & $\stackrel{?}{0.1-0.4}$ & $\stackrel{?}{0.03-0.3}$ & $\begin{array}{c}32 / 33 \\
<0.01-51\end{array}$ & $\begin{array}{c}19 / 19 \\
0.04-74\end{array}$ & $\begin{array}{c}37 / 37 \\
1.59-49\end{array}$ & $\begin{array}{c}34 / 34 \\
0.04-16\end{array}$ \\
\hline & Mercury & & & & & & & & \\
\hline & $\begin{array}{l}\text { FOD } \\
\text { Range }\end{array}$ & $\begin{array}{c}0 / 6 \\
<0.0002\end{array}$ & $\begin{array}{c}0 / 6 \\
<0.0002\end{array}$ & $\begin{array}{c}? \\
<0.001-0.001\end{array}$ & $\begin{array}{l}? \\
<0.001\end{array}$ & $\begin{array}{c}3 / 29 \\
<0.0002 \cdot 0.002\end{array}$ & $\begin{array}{c}1 / 15 \\
<0.0002-0.001\end{array}$ & $\begin{array}{c}1 / 30 \\
<0.0002-0.0002\end{array}$ & $\begin{array}{c}4 / 28 \\
<0.0002-0.009\end{array}$ \\
\hline
\end{tabular}




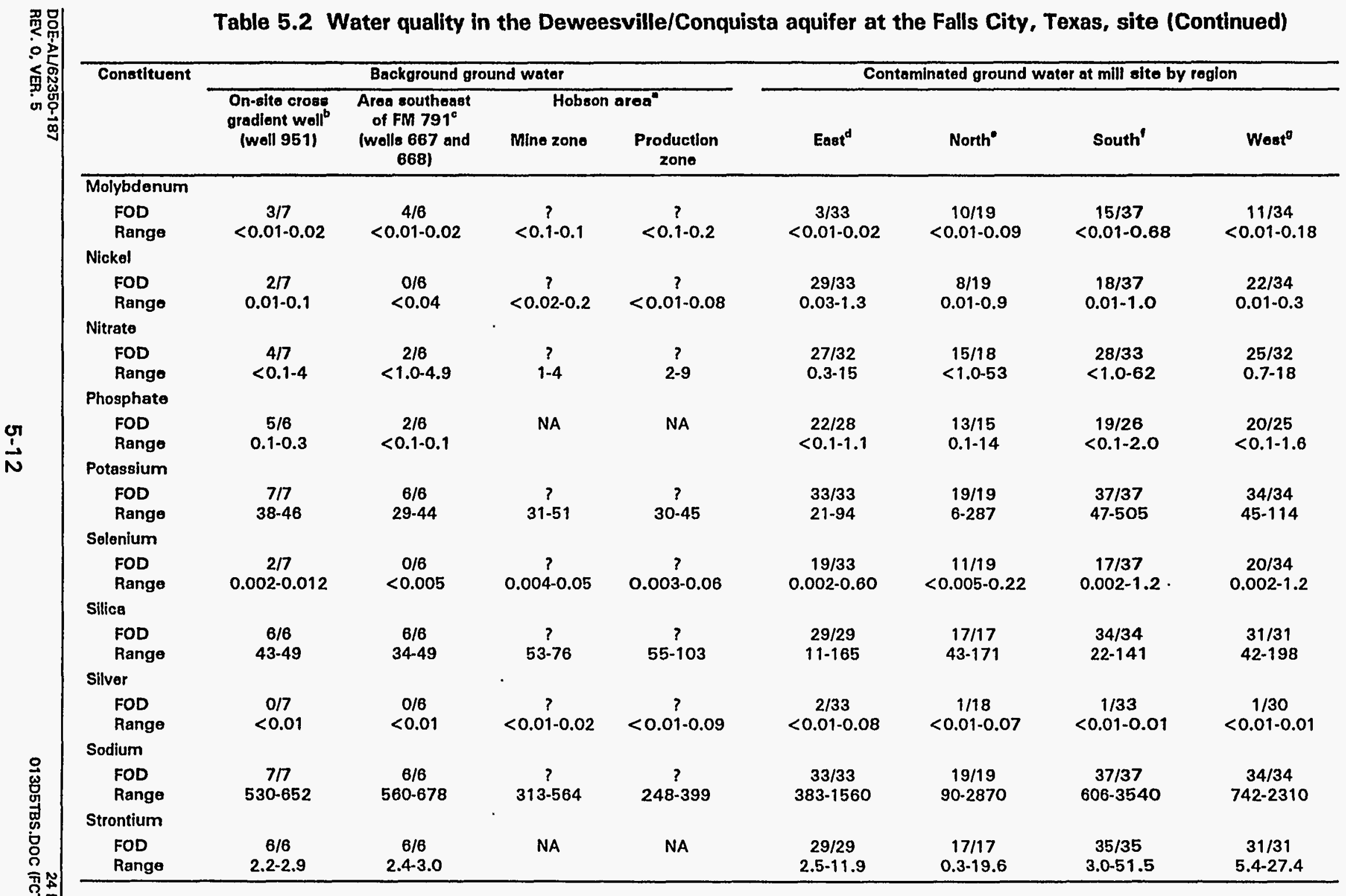




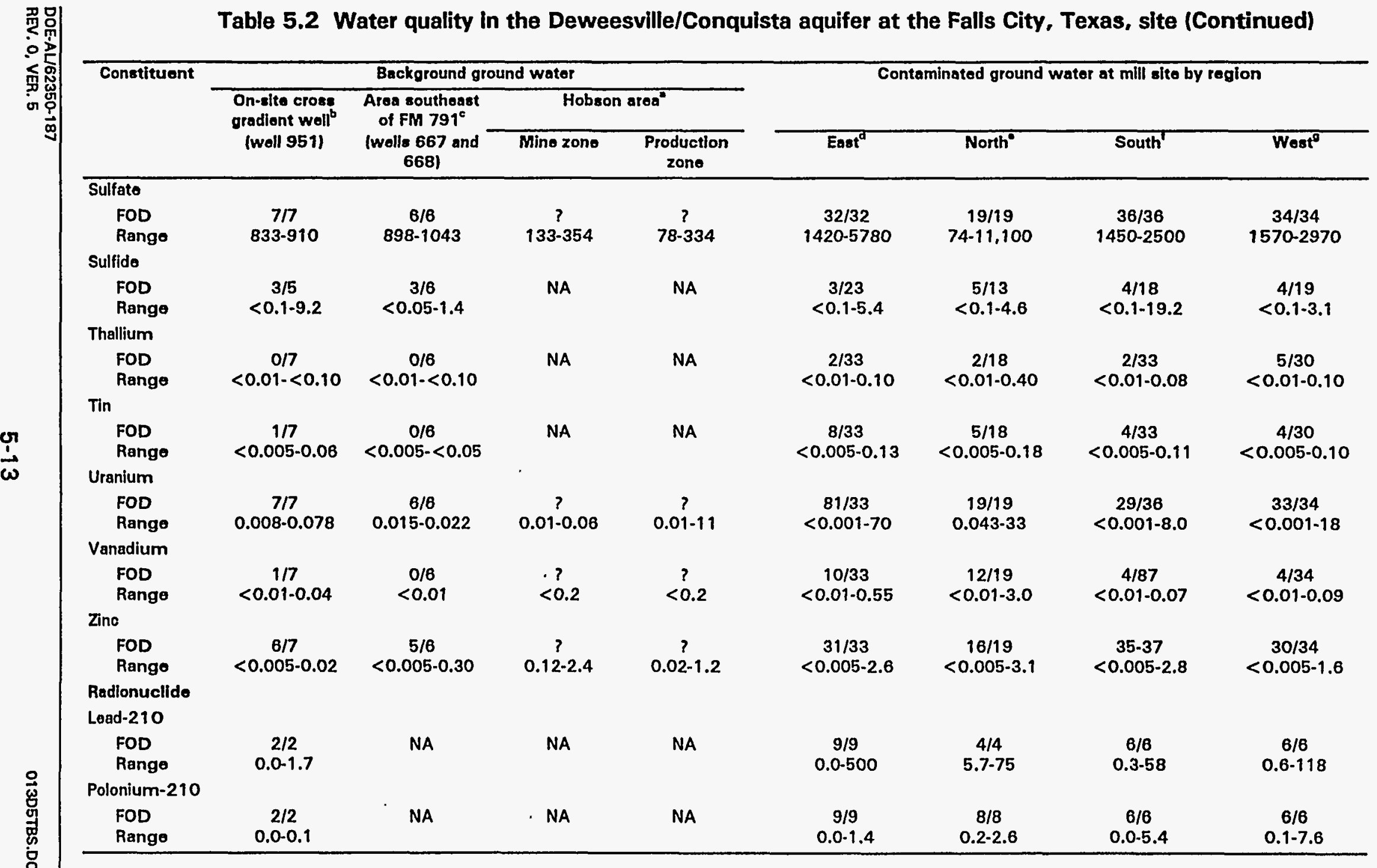


Table 5.2 Water quality in the Deweesville/Conquista aquifer at the Falls City, Texas, site (Concluded)

\begin{tabular}{|c|c|c|c|c|c|c|c|c|}
\hline \multirow[t]{3}{*}{ Constituent } & \multicolumn{4}{|c|}{ Background ground water } & \multicolumn{4}{|c|}{ Contaminated ground water at mill site by region } \\
\hline & \multirow{2}{*}{$\begin{array}{l}\text { On-site crose } \\
\text { gradient woll } \\
\text { (well } 951 \text { ) }\end{array}$} & \multirow{2}{*}{$\begin{array}{c}\text { Area southoast } \\
\text { of FM } 791^{\circ} \\
\text { (wells } 667 \text { and } \\
668 \text { ) }\end{array}$} & \multicolumn{2}{|c|}{ Hobson area" } & \multirow[b]{2}{*}{ East } & \multirow[b]{2}{*}{ North" } & \multirow[b]{2}{*}{ South ${ }^{\prime}$} & \multirow[b]{2}{*}{ West } \\
\hline & & & Mine zone & $\begin{array}{l}\text { Production } \\
\text { zone }\end{array}$ & & & & \\
\hline \multicolumn{9}{|l|}{ Radium-226 } \\
\hline $\begin{array}{l}\text { FOD } \\
\text { Range }\end{array}$ & $\begin{array}{c}7 / 7 \\
1.3-2.7\end{array}$ & $\begin{array}{c}6 / 6 \\
1.9-2.8\end{array}$ & $\stackrel{?}{0.4-15.5}$ & $\stackrel{?}{3.7-1023}$ & $\begin{array}{l}33 / 33 \\
0.0-14\end{array}$ & $\begin{array}{l}18 / 18 \\
0.9-34\end{array}$ & $\begin{array}{c}36 / 36 \\
0.4-140\end{array}$ & $\begin{array}{c}34 / 34 \\
0.2-654\end{array}$ \\
\hline \multicolumn{9}{|l|}{ Thorium-230 } \\
\hline $\begin{array}{l}\text { FOD } \\
\text { Range }\end{array}$ & $\begin{array}{c}2 / 2 \\
0.1-0.4\end{array}$ & NA & NA & NA & $\begin{array}{c}9 / 9 \\
0.0-8.1\end{array}$ & $\begin{array}{c}6 / 6 \\
0.0-46\end{array}$ & $\begin{array}{c}11 / 11 \\
0.2-3.6\end{array}$ & $\begin{array}{l}10 / 10 \\
0.0-54\end{array}$ \\
\hline
\end{tabular}

"Near mine zone - $\mathrm{H} 102, \mathrm{H} 48, \mathrm{B1} 10, \mathrm{~B} 46, \mathrm{~B} 98, \mathrm{~B} 99, \mathrm{~B} 100, \mathrm{~B} 108, \mathrm{~B} 109, \mathrm{~B} 40, \mathrm{~B} 42$, with 11 ground water samples collected from these wells from 1979 to 1981. Production zone wells - T6-A, M95, M94, M93, T92, M10, M9, M7, M5, M3, T95A, M96, M97, M98, P100, P101, I102, I103, 1104, I105, 1106, 1107, M16, M96, M97, M98, H96, H97; 28 ground water samples were collected from these wells from 1978 to 1979.

bMonitor well 951.

'Monitor wells 667 and 668. Filtered-sample data are from 1991.

${ }^{d}$ Wells 940, 953, 955, 963, 965, 966.

${ }^{\circ}$ Wells $625,713,799,880,914,921$.

'Wells 677, 853, 860, 864, 867, 881, 913.

'Wells 854, 859, 882 ,904, 918, 919.

NA - - data not available (sample was not analyzed for this constituent).

?-- detection limit not reported.

FOD - - frequency of detection; the number of measurements at or above detection limits divided by total number of measurements.

Notes:

1. Filtered samples 1989 to April 1993, except as noted.

2. Concentrations are reported in milligrams per liter, except radionuclides which are reported in picocuries per liter.

Ref: DOE, 1994b. 
Table 5.3 Statistical summary of the Dilworth background ground water quality data at the Falls City, Texas, site

\begin{tabular}{|c|c|c|c|c|c|c|}
\hline \multirow[b]{3}{*}{ Constituent } & \multirow[b]{3}{*}{$\begin{array}{l}\text { Number of } \\
\text { samples }\end{array}$} & \multirow[b]{3}{*}{$\begin{array}{c}\text { Detection limit(s) } \\
\text { (mg/L) }\end{array}$} & \multirow[b]{3}{*}{$\begin{array}{l}\% \text { above } \\
\text { detection }\end{array}$} & \multicolumn{3}{|c|}{ Observed concentrations } \\
\hline & & & & Minimum & Modlan & Maximum \\
\hline & & & & & (mg/L) & \\
\hline \multicolumn{7}{|l|}{ Chemical } \\
\hline Aluminum ${ }^{b}$ & 18 & $0.05-0.10$ & 11 & $<0.05$ & NA & 0.05 \\
\hline Ammonium ${ }^{b}$ & 18 & 0.1 & 67 & $<0.1$ & 0.1 & 2.0 \\
\hline Antimony & 22 & $0.003-0.02$ & 9 & $<0.003$ & NA & 0.008 \\
\hline Arsenic (969) & 6 & $0.005-0.010$ & 100 & 0.10 & 0.28 & 0.39 \\
\hline Barium (969) & 6 & $0.01-0.10$ & 100 & 0.04 & 0.05 & 0.10 \\
\hline Beryllium ${ }^{b}$ & 22 & $0.005-0.010$ & 0 & NA & NA & NA \\
\hline Boron (967) & 4 & $0.005-0.10$ & 100 & 0.88 & 1.03 & 1.10 \\
\hline Bromide (969) & 5 & 0.10 & 100 & 2.6 & 3.2 & 5.8 \\
\hline Cadimium & 22 & 0.001 & 27 & $<0.001$ & NA & 0.005 \\
\hline Calcium (969) & 6 & $0.01-2.00$ & 100 & 481 & 502 & 560 \\
\hline Chloride $^{b}(967,969)$ & 11 & 1.0 & 100 & 680 & 793 & 1020 \\
\hline Chromium & 22 & 0.01 & 18 & $<0.01$ & NA & 0.02 \\
\hline Cobalt & 22 & $0.01-0.05$ & 14 & 0.01 & NA & 0.05 \\
\hline Copper & 22 & $0.01-0.02$ & 18 & $<0.01$ & NA & 0.06 \\
\hline Cyanide & 20 & 0.01 & 10 & $<0.01$ & NA & 0.02 \\
\hline Fluoride $^{b}(979)$ & 5 & 0.1 & 100 & 0.4 & 0.4 & 0.5 \\
\hline Iron (969) & 6 & $0.02-0.03$ & 100 & 0.24 & 0.78 & 2.70 \\
\hline Lead & 22 & $0.001-0.1$ & 9 & 0.001 & NA & 0.002 \\
\hline Magnesium (969) & 6 & $0.001-0.5$ & 100 & 54 & 57 & 65 \\
\hline Manganese (969) & 6 & 0.01 & 100 & 2.8 & 3.2 & 3.7 \\
\hline Mercury ${ }^{b}$ & 22 & 0.0002 & 0 & NA & NA & NA \\
\hline Molybdenum $(968,969)$ & 11 & 0.01 & 100 & 0.02 & 0.04 & 0.07 \\
\hline
\end{tabular}


Statistical summary of the Dilworth background ground water quality data at the Falls City, Texas, site (Continued)

\begin{tabular}{|c|c|c|c|c|c|c|}
\hline \multirow[b]{3}{*}{ Constltuent } & \multirow[b]{3}{*}{$\begin{array}{l}\text { Number of } \\
\text { samples }\end{array}$} & \multirow[b]{3}{*}{$\begin{array}{c}\text { Detection limit(s) } \\
\text { (mg/L) }\end{array}$} & \multirow[b]{3}{*}{$\begin{array}{l}\text { \% above } \\
\text { detection }\end{array}$} & \multicolumn{3}{|c|}{ Observed concentrations } \\
\hline & & & & Minimum & Modian" & Maximum \\
\hline & & & & & $(m g / L)$ & \\
\hline Nickel & 22 & $0.01-0.04$ & 9 & 0.01 & NA & 0.01 \\
\hline Nitrate & 22 & $0.1-1$ & 73 & $<1.0$ & 3.3 & 13.0 \\
\hline Phosphate & 18 & $0.1-1$ & 89 & 0.3 & 0.5 & 1.1 \\
\hline Selenium & 22 & $0.002-0.03$ & 36 & 0.002 & NA & 0.024 \\
\hline Silica (968) & 4 & $0.1-2$ & 100 & 88 & 91 & 100 \\
\hline Silver & 22 & 0.01 & 5 & $<0.01$ & NA & 0.02 \\
\hline Sodium $(967,969)$ & 11 & $0.002-5$ & 100 & 482 & 550 & 675 \\
\hline Strontium $^{b}$ (979) & 5 & $0.01-0.1$ & 100 & 1.5 & 1.8 & 77 \\
\hline Sulfate (969) & 6 & $0.1-10$ & 100 & 1220 & 1300 & 1440 \\
\hline Thallium & 22 & $\cdot 0.01-0.1$ & 5 & $<0.01$ & NA & 0.1 \\
\hline Tin & 22 & $0.005-0.05$ & 23 & $<0.005$ & NA & 0.019 \\
\hline Uraniumb $^{\text {(968) }}$ & 5 & $0.001-0.003$ & 100 & 0.026 & 0.056 & 0.068 \\
\hline Vanadium & 22 & 0.01 & 45 & $<0.01$ & NA & 0.05 \\
\hline Zinc & 22 & 0.005 & 68 & $<0.005$ & 0.012 & 0.54 \\
\hline
\end{tabular}




\begin{tabular}{l|l} 
Statistical summary of the Dilworth background ground water quality data at the Falls City, Texas, site \\
(Concluded)
\end{tabular}

The median, or 50th percentile of the sample data, cannot be determined if 50 percent or less of the data are above detection.

bBackground represents data pooled from monitor wells $967,968,969$, and 979 unless one or more of these wells have significantly higher levels than the others. In such cases, the background represents the higher level.

Filtered samples, 1989-1992

NA - not applicable.

Numbers in parentheses are well numbers.

Ref: DOE, 1994b. 
Of the four DOE Dilworth background wells at the Falls City site, three wells (967, 968, and 979) were completed in the oxidized zone, and one well (969) was screened in the transitional zone of the aquifer. Like the Deweesville/ Conquista, ground water quality in the Dilworth is highly variable, including variations in uranium concentrations associated with uranium mineralization (compare data for wells 969, 967, 968, and 979 in Table 5.1).

\subsection{GROUND WATER MONITORING PLAN}

Ground water in the Deweesville/Conquista and Dilworth aquifers is limited use based on widespread ambient contamination that could not be cleaned up with methods reasonably employed by public water systems.

The ground water monitoring plan includes collecting and analyzing ground water samples collected from monitor wells listed in Table 5.4.

Table 5.4 Ground water monitoring network, Falls City, Texas, site

\begin{tabular}{cccc}
\hline & & \multicolumn{2}{c}{$\begin{array}{c}\text { Screened interval } \\
\text { (depth below surface) }\end{array}$} \\
\cline { 3 - 4 } Well number & Member screened & $(\mathrm{ft})$ & $(\mathrm{m})$ \\
\hline 709 & Conquista Sandstone & $18-38$ & $5-12$ \\
858 & Conquista Sandstone & $40-50$ & $12-15$ \\
880 & Deweesville Sandstone & $35-45$ & $11-14$ \\
906 & Conquista Sandstone & $13-28$ & $4-9$ \\
$908^{\mathrm{a}}$ & Conquista Sandstone & $38-58$ & $12-18$ \\
$916^{\mathrm{a}}$ & Conquista Sandstone & $13-33$ & $4-10$ \\
921 & Conquista Sandstone & $45-55$ & $14-17$ \\
\hline
\end{tabular}

${ }^{2}$ Water level measurement only, unless sufficient water is available for sampling.

\subsubsection{Monitoring well network}

The ground water monitoring network consists of the following:

- Four wells (wells $709,858,906,921$ ) screened in the Conquista sandstone of the Deweesville/Conquista aquifer.

- One well (well 880) screened in the Deweesville sandstone of the Deweesville/Conquista aquifer. 
- Two wells (wells 908 and 916) screened in the unsaturated zone of the Conquista sandstone. Historically, these wells have not produced water. These wells will be monitored for water levels to detect changes in ground water levels near the disposal cell.

The monitoring wells are existing wells located nearest to the disposal cell. These wells were chosen because of their shallow depth, completion in the unit having the greatest hydraulic conductivity at the site, and completion in units immediately underiying the disposal cell. Thus, these wells will be responsive to potential changes in water levels and water quality associated with the disposal cell.

With the exception of the well screened in the Deweesville sandstone, all of these wells were completed and sampled prior to surface remedial action construction activities. Water quality data from 4 to 12 sampling rounds are available for these wells. Locations of the wells are shown in Figure 5.2. Monitor well information is provided in Table 5.4. Monitor well completion reports and lithologic logs will be included in the Falls City permanent site file.

\subsubsection{Sampling frequency}

Ground water has been monitored at the Falls City site since 1986. Ground water sampling will be conducted biannually for 5 years after the completion of the disposal cell (until 1999). This sampling frequency will allow evaluation of trends in ground water flow conditions and ground water quality.

\subsubsection{Monitored constituents}

The DOE has identified hazardous constituents in tailings pore fluids and in ground water in the Deweesville/Conquista aquifer. However, because supplemental standards apply to this site, no concentration limits or point of compliance have been established for the identified hazardous constituents because of the highly variable background ground water quality of the Deweesville/Conquista and Dilworth aquifers, and because defining concentration limits and a point of compliance would not further protect human health and the environment (DOE, 1992b). However, the DOE will continue to monitor ground water quality at selected locations as a best management practice to demonstrate that surface remedial action is as close as reasonable to meeting the standard.

\section{Hazardous constituents}

Samples of tailings pore water have been analyzed for hazardous constituents listed in Table 1 to Subpart A (60 FR 2866) and Appendix I to 40 CFR Part 192 (1994) (60 FR 2866). Hazardous constituents were identified from analyses of tailings pore water (DOE, 1992b). The list of these constituents and their levels are provided in Table 5.5 .

Inorganic constituents within the tailings at the Falls City site are mostly metals and metalloid elements associated with the uranium ore and milling process. As shown in Table 5.5, median concentrations of arsenic, cadmium, chromium, molybdenum, 
selenium, uranium, and activities of radium-226 and net gross alpha equal or exceed the maximum concentration limits (MCL) established by the EPA. In addition, nitrate and barium were commonly observed in tailings pore fluids but were typically present at levels below the established MCLs. Lead, mercury, and silver were rarely detected in the tailings pore fluids and, if present, generally occur at levels below the established MCLs.

Those inorganic hazardous constituents without MCLs but which were commonly detected in the tailings pore fluids are antimony, beryllium, cobalt, copper, nickel, sulfide, thallium, tin, vanadium, and zinc (Table 5.5). Cyanide was rarely detected and, if present, occurs at low levels near the limit of detection. Cyanide is not expected in the tailings because cyanide compounds were not used in uranium processing.

Tailings pore water was analyzed for Appendix IX organic constituents (DOE, 1992b). The organic constituents exceeding laboratory method detection limits are benzene, bromoform, chloroform, dibromochloromethane, ethylbenzene, 2methylnapthalene, naphthalene, 1,1,1-trichloroethane, toluene, and xylene. These organic compounds are included as hazardous constituents at the Falls City site (Table 5.6). A more detailed discussion of the organic hazardous constituents is provided in the RAP (DOE, 1992b).

\section{Post-closure monitoring}

Since the Falls City disposal cell is located at the former processing site, and because natural mineralization, mining, and processing activities resulted in ground water contamination on site, post-closure ground water monitoring for demonstration of disposal cell performance based on a set of concentration limits is not appropriate. Nevertheless, monitoring of ground water levels and ground water quality as a best management practice will be useful in evaluating the performance of the disposal cell.

\section{Baseline water quality}

Baseline water quality for the Falls City site is defined as the quality of ground water that has been influenced by uranium processing activities. To establish baseline conditions, each monitor well will be analyzed for constituents given in Table 5.6, including designated inorganic hazardous constituents. In addition to the monitored hazardous constituents, a suite of general water quality indicators (major cations, anions, and standard field measurements) will be monitored and analyzed.

To monitor ground water at the Falls City site, the DOE proposes to use existing wells in proximity to the disposal cell. Water quality has been established for these existing wells prior to and during surface remediation. However, it is possible that 
Table 5.5 Filtered water quality of tailings fluids at the Falls City, Texas, site

\begin{tabular}{|c|c|c|c|c|c|}
\hline Constituent & $\begin{array}{c}\text { Frequency of } \\
\text { detects }\end{array}$ & Minimum & Median & Maximum & MCL \\
\hline \multicolumn{6}{|c|}{ EPA inorganics with MCLs } \\
\hline $\begin{array}{l}\text { Arsenic } \\
\text { Barium } \\
\text { Cadmium } \\
\text { Chromium } \\
\text { Lead } \\
\text { Mercury } \\
\text { Molybdenum } \\
\text { Nitrate } \\
\text { Selenium } \\
\text { Silver } \\
\text { Uranium } \\
\text { Radium-226 } \\
\text { Radium-228 } \\
\text { Net -gross alpha }\end{array}$ & $\begin{array}{l}37 / 58 \\
37 / 55 \\
52 / 58 \\
27 / 55 \\
10 / 55 \\
5 / 24 \\
41 / 58 \\
26 / 40 \\
26 / 58 \\
3 / 54 \\
55 / 55 \\
34 / 34 \\
19 / 19 \\
21 / 40\end{array}$ & $\begin{array}{l}<0.01 \\
<0.01 \\
<0.01 \\
<0.01 \\
<0.005 \\
<0.0002 \\
<0.01 \\
<0.1 \\
<0.005 \\
<0.01 \\
0.044 \\
3.2 \\
0.0 \\
-17309\end{array}$ & $\begin{array}{c}0.12 \\
0.02 \\
0.17 \\
0.05 \\
<0.03 \\
<0.0002 \\
0.14 \\
2.1 \\
<0.05 \\
<0.02 \\
7.57 \\
112 \\
2.5 \\
102\end{array}$ & $\begin{array}{c}6.5 \\
0.10 \\
0.58 \\
0.50 \\
0.08 \\
0.0009 \\
11.4 \\
340 \\
0.60 \\
0.32 \\
109 \\
906 \\
54.1 \\
18996\end{array}$ & $\begin{array}{l}0.05 \\
1.0 \\
0.01 \\
0.05 \\
0.05 \\
0.002 \\
0.10 \\
44 \\
0.01 \\
0.05 \\
0.044 \\
5 \\
5 \\
15\end{array}$ \\
\hline \multicolumn{6}{|c|}{ EPA MCL organics (only those present above detection limits) } \\
\hline $\begin{array}{l}\text { Benzene } \\
\text { Toluene } \\
\text { Xylene } \\
1,1,1 \text {-trichloroethane }\end{array}$ & $\begin{array}{l}1 / 6 \\
1 / 4 \\
4 / 6 \\
1 / 6\end{array}$ & $\begin{array}{c}\text { nd } \\
\text { nd } \\
0.003 \\
\text { nd }\end{array}$ & $\begin{array}{l}\text { nd } \\
\text { nd } \\
0.054 \\
\text { nd }\end{array}$ & $\begin{array}{l}0.002 \\
0.002 \\
0.082 \\
0.002\end{array}$ & $\begin{array}{l}0.005 \\
1.0 \\
10 \\
0.2\end{array}$ \\
\hline \multicolumn{6}{|c|}{ Other Appendix 1 to 40 CFR Part 192 constituents (60 FR 2866) } \\
\hline $\begin{array}{l}\text { Antimony } \\
\text { Beryllium } \\
\text { Bromoform } \\
\text { Chloroform } \\
\text { Cobalt } \\
\text { Copper } \\
\text { Cyanide } \\
\text { Dibromochloro- } \\
\text { methane }\end{array}$ & $\begin{array}{c}12 / 54 \\
49 / 52 \\
1 / 6 \\
3 / 6 \\
52 / 55 \\
43 / 55 \\
2 / 32 \\
1 / 6\end{array}$ & $\begin{array}{c}<0.003 \\
<0.005 \\
\text { nd } \\
0.013 \\
<0.03 \\
<0.01 \\
<0.01 \\
\text { nd }\end{array}$ & $\begin{array}{c}<0.05 \\
0.142 \\
\text { nd } \\
0.025 \\
0.60 \\
0.05 \\
<0.01 \\
\text { nd }\end{array}$ & $\begin{array}{l}0.16 \\
0.62 \\
0.001 \\
0.082 \\
1.70 \\
0.55 \\
0.06 \\
0.001\end{array}$ & $\begin{array}{l}- \\
- \\
- \\
- \\
- \\
-\end{array}$ \\
\hline $\begin{array}{l}\text { Napthalene } \\
\text { Nickel } \\
\text { Sulfide } \\
\text { Thallium } \\
\text { Tin } \\
\text { Vanadium } \\
\text { Zinc } \\
\text { 2-methyl-napthalene }\end{array}$ & $\begin{array}{l}4 / 6 \\
51 / 54 \\
7 / 33 \\
8 / 52 \\
8 / 57 \\
48 / 58 \\
55 / 55 \\
2 / 6\end{array}$ & $\begin{array}{l}0.024 \\
<0.04 \\
<0.1 \\
<0.01 \\
<0.01 \\
<0.01 \\
0.019 \\
0.006\end{array}$ & $\begin{array}{l}0.038 \\
0.92 \\
<0.4 \\
<0.1 \\
<0.1 \\
1.05 \\
3.30 \\
0.010\end{array}$ & $\begin{array}{l}0.066 \\
2.0 \\
55.3 \\
0.60 \\
0.18 \\
8.91 \\
8.6 \\
0.017\end{array}$ & $\begin{array}{l}- \\
- \\
- \\
- \\
- \\
-\end{array}$ \\
\hline
\end{tabular}


Table 5.5 Filtered water quality of tailings fluids at the Falls City, Texas, site (Concluded)

\begin{tabular}{llllll}
\hline Constituent & $\begin{array}{c}\text { Frequency of } \\
\text { detects }\end{array}$ & Minimum & Median & Maximum & $\mathrm{MCL}$ \\
\hline
\end{tabular}

Major elements and water quality parameters

\begin{tabular}{lccccc} 
Aluminum & $55 / 55$ & 0.06 & 616 & 1890 & - \\
Ammonium & $34 / 36$ & $<0.1$ & 295 & 1020 & - \\
Boron & $52 / 52$ & 0.6 & 2.2 & 5.1 & - \\
Bromide & $41 / 49$ & 0.1 & 1.5 & 6.4 & - \\
Calcium & $58 / 58$ & 218 & 510 & 960 & - \\
Chloride & $51 / 51$ & 138 & 1450 & 3340 & - \\
Fluoride & $44 / 45$ & $<0.05$ & 28.2 & 58.8 & - \\
Iron & $58 / 58$ & 0.04 & 412 & 1480 & - \\
Magnesium & $58 / 58$ & 9.6 & 270 & 800 & - \\
Manganese & $58 / 58$ & 0.86 & 28.8 & 95.2 & - \\
pH & $60 / 60$ & 2.39 & 3.13 & 7.17 & - \\
Phosphate & $43 / 43$ & 0.1 & 2.9 & 29 & - \\
Potassium & $58 / 58$ & 5 & 150 & 500 & - \\
Redox potential & $15 / 15$ & 431 & 486 & 606 & - \\
Silica & $44 / 44$ & 43 & 108 & 161 & - \\
Sodium & $58 / 58$ & 236 & 993 & 4090 & - \\
Specific & $56 / 56$ & 1500 & 11250 & 20600 & - \\
$\quad$ conductance & & & & \\
Strontium & $60 / 60$ & 0.44 & 12.5 & 21.8 & - \\
Sulfate & $58 / 58$ & 502 & 8240 & 19700 & - \\
Total dissolved & $59 / 59$ & 922 & 12700 & 34200 & \\
$\quad$ solids & & & & & \\
Total organic & $26 / 26$ & 3 & 43 & 141 & \\
carbon & & & & & \\
\hline Ref DOE, & & & & & \\
\hline
\end{tabular}

Ref: DOE, 1994b.

Notes:

1. All data in milligrams per liter (mg/L) except for radium-226, radium-228 and net gross alpha expressed as picocuries per liter ( $\mathrm{pCi} / \mathrm{L}), \mathrm{pH}$ expressed in standard units, redox potential expressed as millivolts (mV), and specific conductance expressed as micromohs per centimeter $(\mu \mathrm{moh} / \mathrm{cm})$.

2. Maximum concentration level $(\mathrm{MCL})$ is the maximum concentration limit.

3. Data are compiled from the following lysimeters and monitor wells completed in former tailings piles: Lysimeters FCT03-211, -212, -213, -221, -222, -223, -241, -242, -251, $261,-271,-272,-273,-274$; monitor wells FCT03-601, - 602, $-607,-940$.

4. $\mathrm{MCL}$ and data for nitrate are expressed as nitrate $\left(\mathrm{NO}_{3}\right)$ rather than nitrogen $(\mathrm{N})$.

5. MCL for uranium is expressed as $\mathrm{mg} / \mathrm{L}$ natural uranium.

6. Dashes $(-)$ indicate that no MCL has been established by the EPA.

7. ND indicates that the parameter was analyzed for, but not detected. 
Table 5.6 Monitored constituents for establishing baseline conditions at the Falls City, Texas, disposal site

\begin{tabular}{llll}
\hline $\begin{array}{l}\text { Hazardous } \\
\text { Constituents having } \\
\text { MCLs }\end{array}$ & $\begin{array}{l}\text { Hazardous } \\
\text { constituents } \\
\text { without MCLs }\end{array}$ & $\begin{array}{l}\text { Major element } \\
\text { parameters }\end{array}$ & Field parameters \\
\hline Arsenic & Antimony & Aluminum & Alkalinity \\
Cadmium & Beryllium & Ammonium & pH \\
Chromium & Cobalt & Bromide & Redox potential \\
Lead & Copper & Calcium & Temperic conductance \\
Molybdenum & Nickel & Chloride & Tron \\
Nitrate & Sulfide & Magnesium & Manganese \\
Selenium & Thallium & Potassium & \\
Uranium & Tin & Sodium & \\
Radium-226 & Zanadium & Sulfate & \\
Radium-228 & Total dissolved solids & \\
Net gross alpha & & & \\
\hline Noles: & & &
\end{tabular}

Notes:

1. Monitored hazardous constituents are inorganic hazardous constituents detected in more than 10 percent of the tailings fluid samples and having maximum observed levels in excess of maximum concentration limits (MCL), if applicable. See Table 5.5. Hazardous constituents which do not meet these criteria are mercury, silver and cyanide.

2. Filtered samples will be collected for analysis.

surface remediation activities may have influenced ground water in these wells. For example, placement of the cell may have resulted in compaction within the underlying aquifer. The compaction could cause temporary changes in water levels and ground water flow resulting in transient changes in conditions. Such changes are not related to cell performance, and need to be incorporated as baseline data of initial ambient conditions. For this reason, a minimum of four sample rounds from each monitor well will be collected over a 1-year period to establish conditions in the vicinity of the cell. The monitor wells are all located sufficiently far away from the cell such that any transient drainage from the cell itself should not be observed in monitoring wells until 1997, at the earliest. Thus, ambient conditions will be established prior to 1997. These ground water samples will be analyzed for identified hazardous constituents, major element parameters, and field parameters listed in Table 5.6.

\subsubsection{Screening monitoring and exceedance}

Screening monitoring and exceedance was not required at Falls City because there are no concentration limits or point of compliance. However, a screening monitoring program will be conducted to monitor cell performance as a best management practice.

Indicator parameters subsequently will be monitored during a screening phase to determine statistically significant increases (or decreases) over the initial ambient 
conditions. Changes in concentrations of indicator parameters may signal changes in the existing geochemical conditions that influence contaminant transport. One such geochemical condition that influences contaminant transport is the natural capacity of the Conquista sandstone to neutralize the acidic seepage from tailings (BEG, 1992). For this reason existing ground water within the Conquista sandstone generally has a pH in the range of 5.4 to 6.6 as compared to a typical value of 3.1 in the tailings pore waters. By contrast, the Deweesville Sandstone has less neutralization capacity and baseline ground water in the Deweesville remains acidic (pH of about 4). Because $\mathrm{pH}$ is a sensitive indicator of changes in geochemical conditions, and because $\mathrm{pH}$ exerts a major control on contaminant transport, $\mathrm{pH}$ is chosen as the indicator parameter to signal changes in these geochemical conditions.

A determination of whether $\mathrm{pH}$ has varied from baseline in a given well will be made by a statistical comparison to the baseline data. If the results of two successive sampling events exceeds the lower 95th percentile of the baseline $\mathrm{pH}$ data, then the DOE will assess the need for more detailed monitoring by evaluating the statistical findings in conjunction with one or more of the following:

- Reviewing baseline water quality data for pre-existing trends.

- Performing a comparison to water quality in other monitor wells.

- Investigating changes in the major ion concentrations.

- Performing sample reanalysis.

- Checking to ensure that the samples meet quality assurance (QA) requirements.

- Reviewing the statistical distributions of other monitored concentrations and determining whether the sample is an outlier.

- Reviewing field notes for potential errors in sampling locations or procedures.

- Reviewing variations in the hydrologic regime (e.g., water levels, recharge, and climate).

If the assessment confirms the change from initial ambient concentrations, a program of evaluative monitoring may be instituted in which all hazardous inorganic constituents will be analyzed for during the next two sampling events for that monitoring well (and other potentially affected monitor wells) to determine if other constituents are statistically elevated concentrations, and the cause of the deviation from baseline will be evaluated. The DOE will notify the NRC if evaluation monitoring is necessary. Any exceedance of the upper limit (or lower limit for $\mathrm{pH}$ ), an assessment of the data, and evaluative monitoring information will be contained in the site inspection report. If evaluative monitoring indicates the deviation from initial ambient conditions persists and concentrations are trending upward, the DOE will inform the NRC and Texas Department of Health. If evaluative monitoring does 
not indicate a deviation from initial ambient conditions, then the screening program will be re-evaluated, and reinstituted.

Monitored constituents during the screening phase of monitoring will include at least the following:

- Water level.

- Field parameters ( $\mathrm{pH}$, electrical conductivity, oxidation-reduction potential, and temperature).

- Alkalinity, ammonium, calcium, chloride, magnesium, potassium, sodium, sulfate, uranium, molybdenum, selenium, aluminum, iron, manganese, and zinc.

The parameter that will be used as indicator of deviation from baseline will be $\mathrm{pH}$. The additional parameters will be collected to provide a data base for evaluation of deviations, should such evaluation be necessary.

\subsection{CORRECTIVE ACTION}

The EPA's standards (40 CFR \$192.04(c)) require a corrective action program to be implemented within 18 months of verification of an established concentration limit exceedance for one or more of the monitored constituents. The goal of the corrective action program is to restore the disposal cell to its design requirements. NRC regulations (10 CFR $\$ 40.27(c)(5)$ ) specify that the DOE will notify the NRC before implementing any significant corrective action. Section 9.0 provides guidance for implementing a corrective-action program.

If corrective action is determined to be necessary, the DOE will prepare and submit a corrective action plan for NRC review. A copy of this plan also will be transmitted to the state of Texas. The plan will include a monitoring plan to demonstrate the effectiveness of the corrective action, which the DOE will implement after consultation with the NRC and the state of Texas.

As a part of evaluative monitoring, a risk assessment may be conducted to evaluate the potential to human health or the environment harm from the exceedance. If the risk assessment demonstrates no potential harm exists, the corrective action may involve no action except continued monitoring.

\subsection{DATA VALIDATION AND QUALITY ASSURANCE}

The UMTRA Project has established standard operating procedures (SOP) for monitor well installation and development, water sampling, sample preservation and transport, field procedures, and chain of custody for samples.

$Q A$, quality control (QC), analytical data management, and validation will be detailed in the Quality Assurance Implementation Plan being developed in accordance with DOE Order 5700.6C, Quality Assurance. 
Ground water monitoring at the Falls City disposal site will remain the responsibility of the DOE UMTRA Project until the site comes under the NRC general license. Until licensing, all aspects of ground water monitoring will be conducted in accordance with SOPs and the SOPs will be updated regularly to reflect changes in industry standards, best management practices, or EPA guidance. The QA procedures described in this section are consistent with the RCRA Ground Water Monitoring Technical Enforcement Guidance Document (EPA, 1986).

At licensing, the responsibility for ground water monitoring at the Falls City disposal site will be transferred to the GJPO. The GJPO will then be responsible for implementing procedures and developing a QA/QC program consistent with EPA guidance and DOE Orders (Section 12.0).

Sections 5.6.1 through 5.6.4 in the Guidance for Implementing the UMTRA Project Long-term Surveillance Program (DOE, 1992a) summarize standard QA procedures for water sampling and analytical $Q C$ and $Q A$ and data validation.

\section{$5.5 \quad$ REPORTING}

Data and results of the ground water monitoring plan will be reported in the form of an evaluation report once every 5 years to the NRC. At a minimum, the following information will be included in the 5-year performance evaluation reports:

- A table of concentration limits for hazardous constituents.

- A table comparing water quality data to concentration limits.

- A summary of any exceedances of concentration limits.

- Water-quality or water-level data.

- A summary of any resampling, trends, exceedances, evaluative monitoring, or corrective action required during the reporting period.

- Any significant trends or anomalies in the water-quality and water-level data. The narrative will compare collected data to preestablished baseline values.

- Any significant changes in local hydrology.

- The analytical methods used to interpret water quality or indirect monitoring data trends.

- The qualitative or statistical procedure selected to compare ground water quality results with preestablished baseline values.

- A discussion of any new wells or indirect monitoring stations installed, including the rationale for their installation and all completion data. 
- All completed field and laboratory forms.

In addition, the 5-year performance evaluation reports will evaluate the effectiveness of the disposal cell. At a minimum, the reports will also do the following:

- Review historic screening compliance monitoring data.

- Summarize trends in water levels and water quality.

- Include a statistical analysis of historical data, as necessary.

- Evaluate the effectiveness of the disposal cell.

- Determine the effectiveness of the ground water monitoring plan and whether or not the plan should be modified.

The DOE UMTRA Project will submit these reports to the NRC and the state of Texas in compliance with the environmental monitoring requirements of DOE Order 5400.1. All ground water monitoring data and supporting documentation will be part of the permanent site file. The DOE UMTRA Project will be responsible for preparing these reports until responsibility for the site is completely transferred to the GJPO. 


\subsection{SITE INSPECTIONS}

Inspections of the Falls City disposal site will be documented in an inspection report to record any changes to the disposal cell and site over time and to identify potential problems before the need for extensive maintenance, repairs, or corrective action. Fundamental to the inspections will be the detection and documentation of progressive change caused by slow-acting natural processes. The findings from these inspections will be compared to the initial baseline conditions to provide a basis for future inspections. The three types of site inspections are as follows:

- Annual or scheduled site inspections.

- Follow-up inspections.

- Contingency inspections.

Each site inspection must be documented in a report that identifies the findings of the inspection. Copies of the report will be submitted to the NRC and the state of Texas and will be placed in the Falls City permanent site file. Annual or scheduled site inspection reports will be completed and submitted to the NRC within 90 days of the last UMTRA Project site inspection of that calendar year. Follow-up or contingency inspection reports must be submitted to the NRC within 60 days of the initial report and within 60 days after any other type of inspection.

\subsection{INSPECTION FREQUENCY}

The Falls City disposal site will be inspected annually for the first 5 years after licensing. At the end of the 5-year period, the GJPO will evaluate the need to continue annual inspections, basing its recommendation on an evaluation of the annual reports and any other reports filed for maintenance or unscheduled events. If it is determined that less frequent inspections are required, the GJPO will modify the LTSP and submit it to the NRC for approval. The state of Texas will also receive copies for review. Subsequent inspections will be considered a scheduled site inspection.

\subsection{INSPECTION TEAM}

The inspection team will consist of a chief inspector and one or more assistants. The chief inspector will be a geotechnical engineer, a civil engineer, or an engineering geologist knowledgeable in processes that could adversely affect the site (e.g., geomorphic agents of change).

When they are needed for follow-up or assessment inspections, the team will include additional technical experts appropriate to the problems under investigation. 


\subsection{PREPARATION FOR INSPECTION}

Before each inspection, inspectors will complete the following tasks:

- Review the final LTSP, the permanent site file, the previous site inspection report(s) and site inspection map(s), and all maintenance or corrective action reports.

- Prepare the site inspection checklist based on previous inspections or repairs; incorporate any needed modifications.

- Verify and update the names and telephone numbers of all parties with whom access or notification agreements have been executed.

- Verify the DOE 24-hour telephone number and appropriate agency telephone numbers and contacts; arrange to modify the entrance sign, as needed.

- Schedule the site inspection.

- Assemble all equipment needed for the inspection.

- Adjust the Brunton compass's magnetic declination for that of the Falls City area (currently approximately $\mathbf{9 . 5}$ degrees east of north).

- Notify the NRC, the state of Texas, and adjacent land owners for their possible attendance at the inspection. Names and addresses of adjacent land owners are provided in the Falls City permanent site file at the GJPO.

\subsection{SITE INSPECTION AND INSPECTION CHECKLIST}

The site inspection will cover the disposal site area, the disposal cell, and the immediate off-site areas. All site inspection activities and observations should be recorded and described using the as-builts, initial site inspection checklist (Attachment 4), site inspection map, a field notebook, and photographs. Observations and photographic stations should be recorded on the field maps. After the inspection is complete, these maps should be drafted and kept in the permanent site file.

The initial site inspection checklist is a guideline for the inspectors. After each inspection is complete, the checklist will be revised to include new information or to delete items that are no longer pertinent. Revisions to the checklist will be documented in the inspection report.

A photographic record of the site inspection must be maintained. Site conditions should be documented by ground photographs to record developing trends and to enable the DOE to evaluate the need for and extent of future activities. If possible, any site feature or condition requiring inspectors to make 
a written comment, explanation, or description will be photographed. A site inspection photo log will be used to record the photographs (Attachment 3). All features will be photographed and recorded as specified in Section 3.5. The inspectors may determine the number of photographs, the view angles, and the lenses used to ensure that sufficient photographs are taken for agency review.

\subsubsection{Off-site areas}

The area within a maximum of $0.25 \mathrm{mi}(0.40 \mathrm{~km})$ from the center of the disposal site will be surveyed for evidence of land-use changes that indicate increased human activity (i.e., greater probability of intrusion onto the site). New roads or paths, changes in vegetation, and relevant geomorphic features like gullies or aeolian formations, any of which could initiate site-threatening erosion, will also be observed.

\subsubsection{On-site areas}

The integrity of the disposal cell will be evaluated from a series of transects walked around the perimeter; along the base, crest, and sideslopes; and in and around the apron. Sufficient transects must be walked so that the disposal cell is thoroughly covered and inspected. Diagonal transects of the crest will be made, and the edge of the crest will be walked. Additional transects, at approximately 50-yd (46-m) intervals, will be walked along the sideslopes. Transects along the entire length of each diversion channel will be made to determine whether the channels have been functioning and can be expected to continue to function as designed.

At minimum, the site perimeter and site area transects will be monitored for damage to or disturbance of the following features:

- Fences, gates, and locks.

- Permanent site-surveillance features.

- Ground water monitor wells.

- Site area vegetation or volunteer plant growth.

- Sedimentation or erosion.

The complete length of transects along the engineered component (diversion channels and disposal cell sideslopes, and crest) will be walked and examined for evidence of the following:

- Structural instability resulting from differential settlement, subsidence, cracking, sliding, or creep.

- Erosion as evidenced by developing rills or gullies.

- Sedimentation or debris. 
- Rapid rock cover deterioration caused by weathering or erosion.

- Removal of rock or other disposal cell material.

- Seepage.

- Intrusion (inadvertent or deliberate) by humans or animals.

- Animal burrowing.

- Vandalism.

- Trails showing human or animal activity.

- Volunteer plant growth.

\subsection{MODIFYING PROCESSES}

Modifications from natural processes will most likely be on the topslopes and the lower portions of the sideslopes of the disposal cell and in and around the apron. Plant and animal intrusion can also cause modifications to engineered components of the disposal cell. The inspection report will detail any observed modifying features, and will include a description of the problem, relevant measurements and photographs, and an assessment of possible impacts. The description of the modifying process will include information such as the following:

- Extent of area affected.

- Number, spacing, length, depth, and width of features (e.g., gullies).

- Patterns of occurrence.

- Species present, if plant or animals are found at the site.

- Location and density of volunteer plant growth.

Inadvertent or casual intrusion by humans or animals is not of great concern, but evidence of cover removal, extensive vandalism to signs and monuments, or the presence of well-established trails will be described in detail. Continued vandalism may require more active measures to control site access.

If new conditions requiring monitoring or immediate action are discovered during the inspection, the inspection report should include a description of the problem and the recommended follow-up action (if required). 


\subsection{VEGETATION}

\subsubsection{Planned vegetation}

The top of the disposal cell is a vegetative cover. A 6-inch (152- $\mathrm{mm})$ layer of topsoil was placed on top of the 3-foot $(0.9-\mathrm{m})$-thick growth medium material.

The soil was fertilized with a standard commercial grade fertilizer consisting of 77 percent nitrogen and 23 percent phosphate. The amount placed was an average of 262 pounds per acre (lb/ac) (293 kilograms/hectare [kg/hal).

Prior to seed application, the top of the disposal cell was disced and raked to ensure that 6 inches $(152 \mathrm{~mm})$ of topsoil was in a loose, friable condition pursuant to seeding specifications. All seeding was accomplished with a range land drill set at 0.5 inches $(13 \mathrm{~mm})$ to 0.75 inches $(19 \mathrm{~mm})$, per specifications.

The topslope was planted with the following seed ratio and poundage:

$\begin{array}{lcc}\text { Green Sprangletop } & \begin{array}{c}165.0 \mathrm{lbs} \\ (71.9 \mathrm{~kg})\end{array} & \begin{array}{l}1.90 \mathrm{lb} / \mathrm{acre} \\ (2.12 \mathrm{~kg} / \mathrm{ha})\end{array} \\ \text { Common Bermuda } & \begin{array}{l}888.0 \mathrm{lbs} \\ (402.8 \mathrm{~kg})\end{array} & \begin{array}{l}10.20 \mathrm{lb} / \mathrm{acre} \\ (11.40 \mathrm{~kg} / \mathrm{ha})\end{array} \\ & \begin{array}{l}74.7 \mathrm{lbs} \\ (33.9 \mathrm{~kg})\end{array} & \begin{array}{l}0.96 \mathrm{lb} / \mathrm{acre} \\ (1.1 \mathrm{~kg} / \mathrm{ha})\end{array} \\ \text { Sideoats Grama } & 447.0 \mathrm{lbs} & 5.14 \mathrm{lb} / \mathrm{acre} \\ & (202.8 \mathrm{~kg}) & (5.74 \mathrm{~kg} / \mathrm{ha}) \\ \text { Kleingrass } & & 18.20 \mathrm{lb} / \mathrm{acre} \\ & & (20 \mathrm{~kg} / \mathrm{ha})\end{array}$

After completion of the disposal cell, a plant specialist or other qualified person will periodically participate in site inspections. If the inspection does not coincide with the general growing season, the plant specialist may conduct a separate inspection at a more favorable time. Conditions such as drought may cause the vegetative cover to die. This may require reseeding, which should be coordinated with the local U.S. Soil Conservation Service agent.

\subsubsection{Volunteer plant growth}

Volunteer plant growth includes plants growing where none were planned, such as in rock-lined drainage ditches, or unwanted plant species growing on the vegetated topslope of the disposal cell.

A follow-up inspection by a plant specialist may be required if an inspection team reports woody plant species such as mesquite growing on the vegetative 
cover. It is anticipated that the growth of woody species on the vegetative cover will be minimized after the grass cover has become well established. Woody plants and other unwanted plant species will be eliminated from the cover. This elimination may involve selective spraying or mechanical removal.

\subsection{SITE INSPECTION MAP}

A new site inspection map will be prepared after each scheduled inspection using the disposal site map (Plate 2) as a base. This map must include the following:

- Inspection traverses.

- Photographic locations.

- Locations and descriptions of any new, anomalous, or unexpected features.

- Features identified during previous inspections for observation or monitoring.

- Inspection date.

\subsection{REPORTING REQUIREMENTS}

Upon completion of the field inspection, Section D of the initial site inspection checklist (Attachment 4) must be completed and the certification statement must be signed. Overlays for the as-built drawings or revised drawings will be developed, noting any potential problems or other site conditions requiring attention. The revised drawings will be labeled with the date and type of site inspection.

All photographs must be logged on a site inspection photo log (Attachment 3). A separate photo log should be completed for each roll of exposed film, with an entry for each photograph. The completed photo logs should be attached to the inspection checklist and paginated accordingly.

Documentary evidence of anomalous, new, or unexpected conditions or situations must be included to record developing trends and to enable the responsible agency to make reasonable decisions concerning follow-up inspections, custodial maintenance, and/or repair, and corrective action. Photographs may be considered to be documentation.

A site inspection report including the following information will be completed after every routine site inspection:

- Narrative of site inspection, including results, conclusions, and recommendations. 
- Site inspection checklists and all relevant supporting documentation.

- Site inspection map and other drawings, maps, or figures, as required.

- Inspection photographs and photo log sheet.

- Recommendations for additional follow-up inspections, or custodial maintenance and/or repair, if required.

- Follow-up or contingency inspection reports, if required.

- Custodial maintenance and/or repair report and certification, if required.

- Inspection certification.

- Ground water monitoring data and analyses, if applicable.

Appendix A, Criterion 12 of 10 CFR Part 40 requires the DOE to submit results of all routine site inspections to the NRC and the state of Texas within 90 days of the last UMTRA Project site inspection for that calendar year. A copy of all site inspection reports will be maintained in the permanent site file and a copy of the inspection report will also be sent to the state of Texas. 


\subsection{UNSCHEDULED INSPECTIONS}

An unscheduled inspection may be triggered by reports or information that site integrity has been or may be compromised.

\section{$7.1 \quad$ FOLLOW-UP INSPECTIONS}

Follow-up inspections investigate and quantify specific problems found during a scheduled inspection, ground water sampling event, special study, or other DOE activity. They determine whether processes currently active at or near the site threaten site security or stability, and they evaluate the need for custodial maintenance and/or repair or corrective action.

Follow-up inspections should be made by technical specialists in an appropriate discipline (e.g., a soils scientist or geomorphologist to evaluate erosion processes).

The follow-up inspection begins with an on-site visit to determine the need for definitive tests or studies. Additional visits may be scheduled if more data are needed to draw conclusions and recommend corrective action. If custodial maintenance or repair or corrective action is warranted, the DOE will notify the NRC, the state of Texas, and the adjacent residents.

\subsection{CONTINGENCY INSPECTIONS}

Contingency inspections are unscheduled inspections ordered by the DOE when it receives information indicating that site integrity has been or may be threatened. Events that could trigger contingency inspections include severe vandalism, intrusion by humans or livestock, severe rainstorms, or unusual events such as tornados or earthquakes.

An assessment of each unusual event must be submitted to the NRC within 60 days of the initial report that damage or disruption has occurred at the Falls City disposal site (10 CFR Part 40). The state of Texas will receive a copy of this report. At a minimum, this report must include the following:

- A description of the problem.

- A preliminary assessment of the custodial maintenance or repair or corrective action required.

- Conclusions and recommendations.

- Assessment data, including field and inspection data, and photographs.

- Names and qualifications of the field inspectors. 
A copy of the report and all other data and documentation will be maintained in the permanent site file. The annual report to the NRC will include the results of these contingency inspection reports. If appropriate, the annual (or scheduled) Falls City site inspection report will also contain the results of these inspections.

After reviewing the preliminary inspection/assessment report, the DOE must submit a corrective action plan for NRC approval and to the state of Texas within the 60-day period required by 10 CFR Part 40 . Based on the findings of these reports, the GJPO will complete corrective action, following the guidance for implementing corrective action described in Section 9.0. 


\subsection{CUSTODIAL MAINTENANCE OR REPAIR}

Custodial maintenance will be performed as needed at the Falls City disposal site; no maintenance is scheduled. Annual site inspections, follow-up inspections, and contingency inspections will determine the need for maintenance or repairs.

\subsection{PLANNED MAINTENANCE}

No routine maintenance is planned for the Falls City disposal site.

\subsection{UNSCHEDULED MAINTENANCE OR REPAIR}

Unscheduled custodial maintenance or repair required at the Falls City disposal site may include the following:

- Repairing the gate.

- Replacing the entrance sign.

- Removing deep-rooted plants that invade the vegetated topslope of the disposal cell and infilling all animal burrows on the disposal cell.

- Reseeding the topslope if drought or other factors eliminate much of the vegetative cover.

The GJPO will prepare a statement of work (SOW) and purchase order to authorize these kinds of repair. The SOW will include contractor qualifications.

If problems are identified that may affect the integrity of the disposal cell or compliance with the EPA standards, the NRC must approve the recommended action in advance. The action will be treated as a corrective action.

\subsection{CERTIFICATION AND REPORTING REQUIREMENTS}

The site inspection report and the annual report to the NRC must include the following information on unscheduled maintenance or repair:

- Summary of work required.

- Work order, purchase order, or SOW.

- Contractor qualifications, if applicable.

- Contractor documentation of work completion.

- DOE certification of work completion. 
After the work is completed, the contractor must submit verification of the completed work and/or a written report if the action is considered significant. The DOE will inspect the site, as necessary, and review the report before certifying that all work is completed in accordance with all required specifications. Copies of all records, documentation, and certifications will be included in the Falls City permanent site file. Copies of all relevant documentation will be transmitted to the state of Texas. 


\subsection{CORRECTIVE ACTION}

If natural or unforeseen events threaten the stability of the disposal cell, corrective action could include temporary emergency measures. In addition, the DOE would evaluate the factors that caused the problem to minimize or avoid their recurrence. The following conditions could require corrective action:

- Surface rupture of the disposal cell (could indicate differential settlement or severe shrinkage of the cover materials).

- Subsidence, sliding, or slope instability on the disposal cell (caused by mass wasting, liquefaction, differential settlement, or other events).

- Development of rills or gullies on the disposal cell.

- Deterioration of the erosion protection rock on the disposal cell or in the drainage ditches.

- Seepage originating from the disposal cell or the toe of the cell.

- Gully development on or immediately adjacent to disposal site property that could affect the integrity of the disposal cell.

- Rapid headward cutting of a gully, arroyo, or ravine that threatens the stability of the disposal cell.

- Damage to the cell cover or disposal site property from extreme seismic events, other catastrophic events, or vandalism (e.g., removal of cell construction materials).

- Verification of an excursion during the ground water monitoring program.

When a potential problem is identified, the DOE will notify the NRC and the state of Texas and will submit an inspection/preliminary assessment report for NRC review no more than 60 days after the problem is identified. The preliminary assessment report will evaluate the problem and recommend the next step (e.g., immediate action or continued evaluation). After the NRC reviews the report and recommendations, the DOE will develop a corrective action plan for NRC approval. The DOE may combine the inspection and recommendation in one report, depending on the severity of the problem. Once the NRC approves the corrective action, the DOE will implement the plan. Figure 9.1 illustrates the sequence of events in the corrective action process. Figure 9.2 identifies the key elements in the corrective action process. 
PROBLEM INDICATING CORRECTIVE ACTION IDENTIFIED

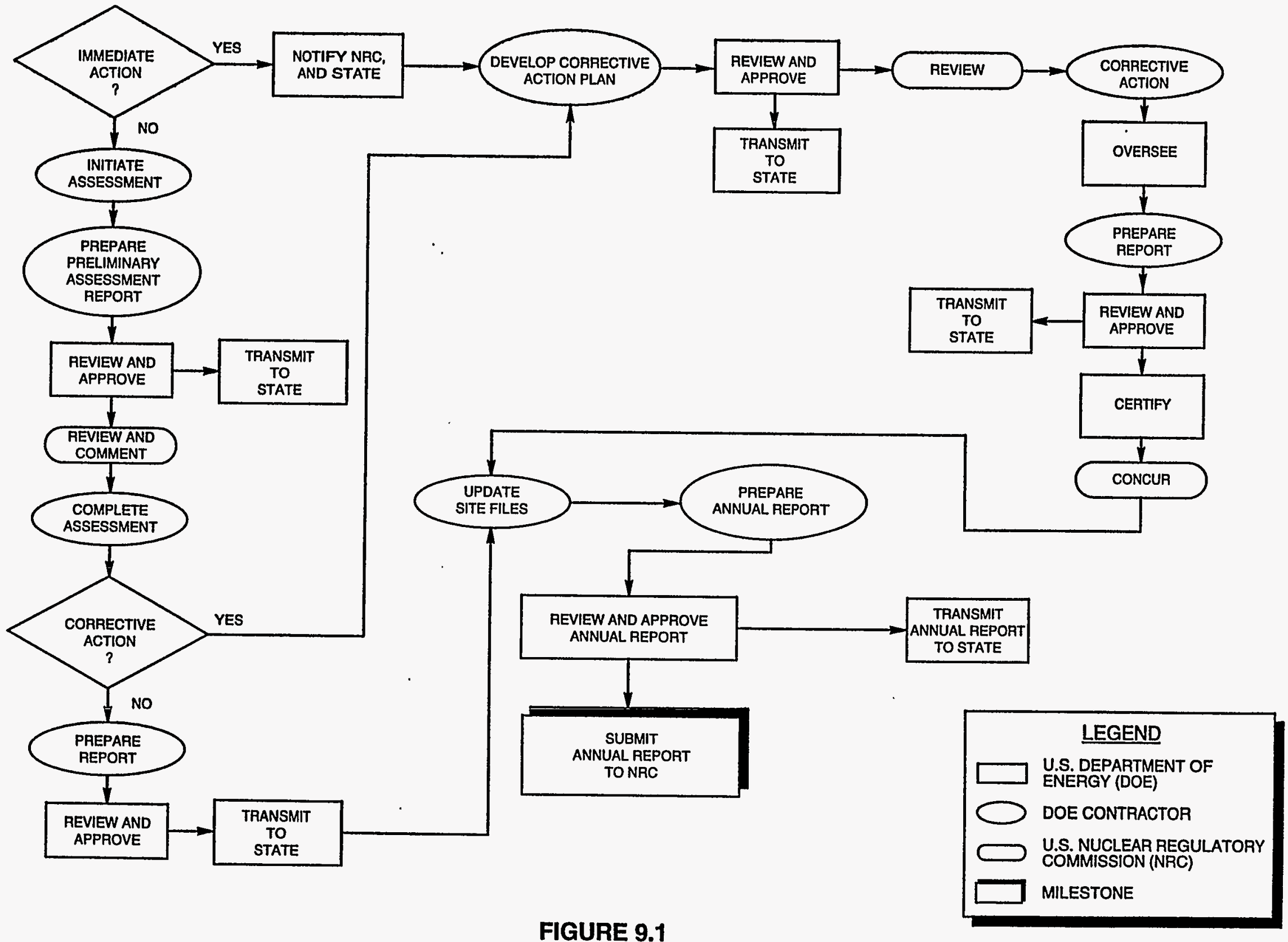




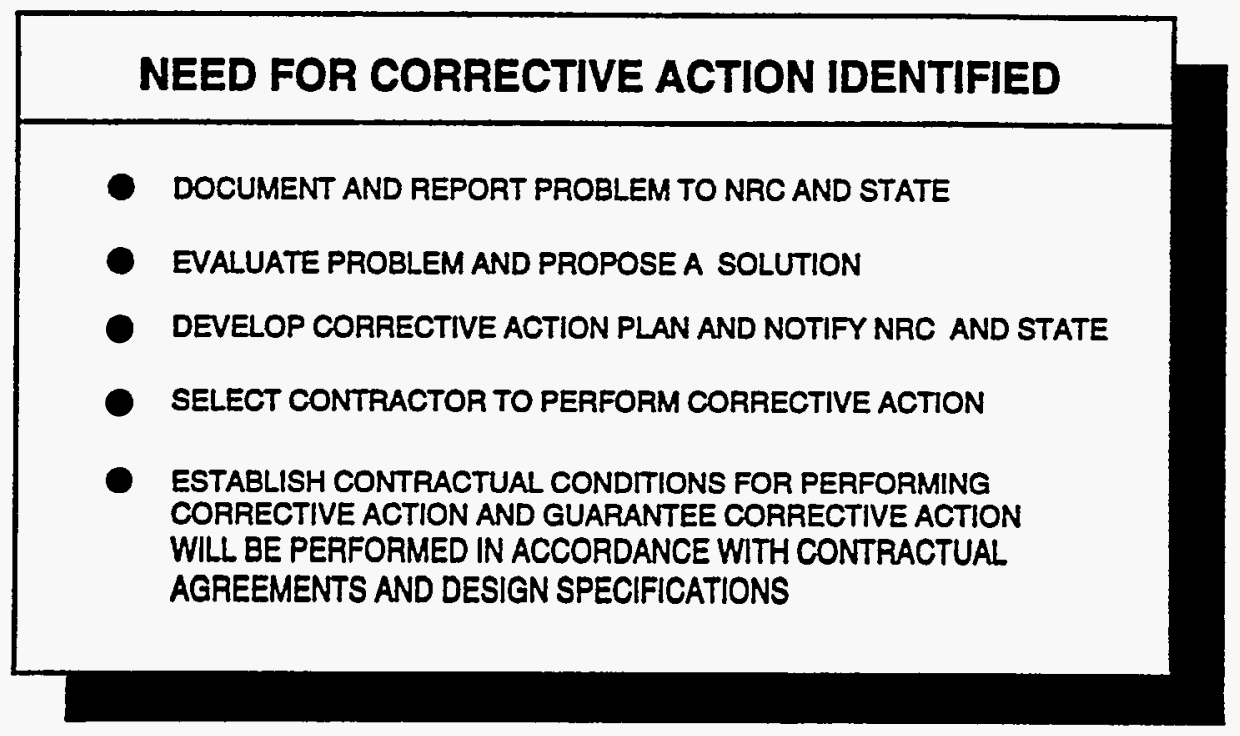

\section{CORRECTIVE ACTION IMPLEMENTATION}

- MONITOR PROGRESS OF CORRECTIVE ACTION

- VERIFY COMPLETION OF CORRECTIVE ACTION

\section{CORRECTIVE ACTION CERTIFICATION}

VERIFY CORRECTIVE ACTION AS DESIGNED CORRECTS

THE PROBLEM

- ENSURE RECURRENCE OF PROBLEM IS MINIMIZED OR AVOIDED

- CERTIFY COMPLETION OF CORRECTIVE ACTION IN ACCORDANCE WITH EPA STANDARDS

- SUBMIT CERTIFICATION REPORT TO NRC

FROM DOE, 1992a.

FIGURE 9.2

KEY ELEMENTS IN THE CORRECTIVE ACTION PROCESS 
NRC regulations do not stipulate a time frame for implementing corrective action. However, EPA standards (60 FR 2866) requires that a corrective action program begin within 18 months after a finding of an exceedance in established ground water concentration limits. Assessing the extent of a problem and developing a corrective action plan will not be considered initiation of the corrective action program. Section 9.0 of the UMTRA LTSP guidance document (DOE, 1992a) contains details on corrective action.

\subsection{PROBLEM IDENTIFICATION}

Site inspections by qualified inspectors and routine custodial maintenance are designed to identify problems at the developmental stage, thus eliminating the need for corrective action. However, extreme natural events, vandalism, or unanticipated events may require additional data or evaluative monitoring to assess whether uncorrected problems would threaten site integrity. An on-site inspection/preliminary assessment would include, but not be limited to, the following:

- Identifying the nature and extent of the problem.

- Reevaluating germane engineering design parameters.

- Establishing a data collection and/or evaluative monitoring program to quantify the magnitude of the problem.

\subsection{CERTIFICATION AND REPORTING PROCEDURES}

The DOE will prepare progress reports on each corrective action while it is under way or under evaluation. The NRC will receive a copy of each report, or the reports will be attached to the annual report. The NRC will be informed of all potential problems and solutions. All reports will also be provided to the state of Texas.

After corrective action is complete, all work will be certified in accordance with EPA standards. The NRC will review this certification. A copy of the certification statement will become part of the permanent site files, as will all reports, data, and documentation generated during the corrective action. 


\subsection{RECORD KEEPING AND REPORTING REQUIREMENTS}

The DOE will maintain a permanent site file containing all information needed to prepare for and conduct site surveillance. Carefully compiled, complete, accurate reports of site-surveillance activities will be maintained in accordance with archival procedures set forth in 41 CFR Part 101 and 36 CFR Parts 1220-1238 (Subchapter B - Records Management).

As required by 55 FR 45591, the DOE will provide an annual report to the NRC documenting the results of the long-term surveillance program. Copies of the annual report will be provided to the state of Texas and will be added to the Falls City permanent site file. The annual reports and supporting documentation in the permanent site file will accomplish the following:

- Document the history of disposal site performance.

- Demonstrate to the NRC that licensing provisions were met.

- Provide the DOE and the NRC with information needed to forecast future sitesurveillance and monitoring needs.

- Inform the public that site integrity has been maintained.

\subsection{RECORDS}

The GJPO will maintain the Falis City permanent site file in Grand Junction, Colorado. All original deeds, custody agreements, and other property documents will be kept at the DOE Facilities and Property Management Division, Albuquerque, New Mexico. Copies of these documents will also be maintained in GJPO files.

Surveillance and maintenance documentation will be maintained at the GJPO as a separate record collection from the UMTRA Project Document Control Center. As such, the records will be handled in accordance with DOE Order 1324.2A, Records Disposition, to ensure their proper handling, maintenance, and disposition.

The GJPO will update the Falls City permanent site file as necessary, after annual disposal site inspections are complete. Original UMTRA Project records and files will be archived at the DOE UMTRA Project, Albuquerque, New Mexico. Copies of the documentation and annual updates and additions will be kept in the permanent site file held by the GJPO, Grand Junction, Colorado. All information will be available for NRC and public review. 


\subsection{REPORTS}

The GJPO will provide an annual report to the NRC, documenting the results of annual site inspections and any other activities conducted in conjunction with the long-term surveillance program. Criterion 12 to Appendix A of 10 CFR Part 40 stipulates that the annual report must be submitted no more than 90 days after the date of the last UMTRA Project site inspection for that calendar year.

The GJPO also will submit reports to the NRC documenting follow-up or contingency inspections and any corrective action plans. If any unusual damage or disruption is discovered, Criterion 12 requires that all preliminary inspection reports must be submitted within 60 days of the discovery.

The results of the ground water monitoring program will be reported annually to the NRC. The DOE UMTRA Project will be responsible for preparing these ground water monitoring reports until this responsibility is transferred to the GJPO. 


\subsection{EMERGENCY NOTIFICATION AND REPORTING}

The Falls City disposal cell was designed to comply with EPA standards (40 CFR Part 192, 60 FR 2865) with minimum maintenance and oversight for a period of 1000 years, or at least 200 years. However, unforeseen events could create problems that could affect the disposal cell's ability to remain in compliance with EPA standards. Therefore, the DOE has requested notification from state, federal, and local agencies of discoveries or reports of any purposeful intrusion or damage at the disposal site as well as the occurrence of earthquakes, tornados, or floods in the disposal site area.

\subsection{AGENCY AGREEMENTS}

The DOE is negotiating notification agreements with the Karnes County Sheriff's Department , the USGS National Earthquake Information Center (Denver, Coloradol, and the Texas Office of the National Weather Service. Copies of the agreements will be presented in Attachment 5. The designated point of contact for emergency notification is the GJPO 24-hour phone line (970-248-6070). This number is posted on the Falls City disposal site entrance sign so the public can notify the DOE, if problems are discovered.

In accordance with the agreements, the DOE UMTRA Project will be the designated facility contact until the Falls City disposal site is brought under general license. After that, the designated facility contact will be the GJPO.

Response letters from all of the agencies will be kept in the permanent site file.

Contact lists and telephone numbers for all agencies with whom the DOE has entered into agreements will be updated annually, in conjunction with the site inspection, for inclusion in the disposal site inspection report. To further solidify written agreements with these agencies, the GJPO will contact these agencies periodically to update them about the concerns for the Falls City disposal site.

\subsection{UNUSUAL OCCURRENCES}

The DOE has requested that the Karnes County Sheriff notify the GJPO notified of any unusual occurrences in the disposal site area that may affect surface or subsurface stability.

\subsection{EARTHQUAKES}

The DOE subscribes to the USGS Early Warning Service for notification when an earthquake is of sufficient magnitude to threaten a disposal site. This service provides data on the magnitude of the event and the location of the epicenter.

The USGS National Earthquake Information Center has agreed to notify the DOE GJPO if a seismic event occurs that fits any of the following descriptions (Attachment 5): 
- Any earthquake of magnitude 3.0 or greater, within 0.3 degree (about $20 \mathrm{mi}[30 \mathrm{~km}]$ at $\mathrm{N} 28.91^{\circ}$ latitude and W98.13 longitude) of the site.

- Any earthquake of magnitude 5.0 or greater, within 1.0 degree (about $70 \mathrm{mi}[110 \mathrm{~km}]$ at $\mathrm{N} 28.91^{\circ}$ latitude and W98.13 longitude) of the site.

\subsection{METEOROLOGICAL EVENTS}

The Texas office of the National Weather Service in New Braunfels, Texas, has agreed to notify the GJPO within 8 hours of issuing a flash flood or tornado warning in Karnes County, Texas (Attachment 5). 


\subsection{QUALITY ASSURANCE}

The GJPO is responsible for developing QA procedures specific to the UMTRA Project longterm surveillance program. The GJPO Long-Term Surveillance Program Quality Assurance Program Plan (DOE, 1992c) specifies the following requirements:

- Program planning.

- Program activities, including inspections, site maintenance, corrective action, and emergency responses.

- Monitoring, if required.

- Personnel qualifications and training.

- Program surveillance and audits.

- $\quad$ Analytical QA.

- Analytical data validation.

All site inspections, monitoring data, records, photographs, maps, and other information related to the LTSP for the Falls City disposal site are subject to formal and unannounced audits by the DOE UMTRA Project or the NRC. Specific QA criteria have already been developed for aerial photographs (DOE, 1992a).

\section{Ground water monitoring}

Ground water monitoring is required for compliance with 60 FR 2854 at the Falls City disposal site. Ground water monitoring will be conducted by the DOE UMTRA Project until the site is licensed. Thereafter, site monitoring under the LTSP will be conducted by the GJPO. Prior to transferring a licensed disposal site to the GJPO, the UMTRA Project will . ensure that the GJPO's QA/OC procedures for ground water monitoring (including sample collection, laboratory analysis, and data validation) are consistent with standard industry practices as implemented in applicable SOPS in the UMTRA TAC SOP manual (JEG, n.d.) and all applicable regulations.

QA activities for ground water monitoring will describe the policy, organization, functional activities, and $\mathrm{QA} / \mathrm{QC}$ protocols needed to achieve the data quality objectives (DQO) of the intended use of the data. Specifically, QA activities will do the following:

- Identify the organizations involved with ground water monitoring activities and describe their operational, field, laboratory, and QA responsibilities. 
- Discuss procedures for field and laboratory analysis of environmental samples and for sample custody, handling, packaging, shipping, and documentation. Laboratory analyses of environmental samples include the following:

- Inorganic, organic, and radiological constituents.

- Other chemical, physical, and water-quality parameters.

- Discuss QA in field measurements. The QA procedures for field and laboratory methods appear in applicable SOPs in the UMTRA TAC SOP manual (JEG, n.d.). When an SOP has not been completed for an activity, best management practices (standard industry procedures) will be followed.

- Describe data validation, QA/OC, data reporting, calibration frequency, and preventive maintenance procedures for field and laboratory equipment.

- Establish guidance on internal QC checks and data reduction, validation, and reporting requirements for field and laboratory environmental samples.

- Present UMTRA Project system audit procedures and technical, field, and laboratory performance audit procedures.

- Recommend field and laboratory corrective action and update procedures for corrective action resulting from audits.

- Present QA reporting procedures, outlining reporting requirements to management.

- Describe the record-keeping system. 


\subsection{PERSONNEL HEALTH AND SAFETY}

DOE Order 5480.1B, Environment, Safety and Health Program for DOE Operations, establishes personnel health and safety procedures for all DOE operations. After a disposal site is licensed and transferred to the GJPO, the GJPO is responsible for health and safety procedures for GJPO personnel. The GJPO will determine health and safety requirements for its personnel and GJPO subcontractors in accordance with applicable orders and federal regulations. The disposal cell was designed and constructed to control Ra-226 and radon222 releases from the residual radioactive material (60 FR 2865); therefore, radiation exposure tracking and dosimetry badges are not needed.

\subsection{HEALTH AND SAFETY INSPECTIONS}

The inspector's health and safety training and certifications; the locations, and telephone numbers for emergency medical and law enforcement facilities; and the facility contact 24 -hour telephone number will be verified before each site inspection.

Specific safety concerns at the Falls City disposal site include slip, trip, and fall hazards; animal, snake, and insect bites; animal and bird hunting seasons; heat and cold stress; fire hazards; puncture and cut hazards; and road hazards. Safety equipment should be taken to the site to reduce exposures to identified hazards and to provide first aid to anyone at the site who may need it.

\section{Emergency medical and law enforcement}

Local emergency medical and law enforcement agencies were briefed on the scope of work at the site during the long-term surveillance and maintenance phase. The following 24-hour emergency numbers are pertinent:

- Fire: 911 or (210) 254-3211 (Falls City, Texas)

- Ambulance: 911 or (210) $780-3931$ (Karnes City, Texas)

- Police: 911 or (210) 780-3931 (Karnes City, Texas)

- Sheriff: 911 or (210) 780-3931 (Karnes City, Texas)

- Texas Highway Patrol: (210) 780-3931 (Karnes City, Texas)

Medical care is not available in Falls City. Three hospitals are within an approximate $15-$ mile $(24-\mathrm{km})$ radius of Falls City. Both outpatient and emergency treatment are available at each hospital. The nearest emergency room is located at Otto Kaiser Hospital in Kennedy, Texas, on Highway 181. Medical care is also available in San Antonio (DOE, 1991). Personnel traveling to the site should ensure that at least one if not all personnel have taken first aid/cardiopulmonary recuscitation training. 


\section{Directions to Otto Kaiser Hospital}

Otto Kaiser Hospital is approximately half way between Karnes City and Kennedy on the left (north) side of Highway 181 at its junction with a county road.

Directions to Otto Kaiser Hospital from the site are as follows:

- From the Falls City site proceed southeast on FM Road 1344 to FM Road 791.

- Turn left onto FM Road 791 and follow it northeast into Falls City.

- At Falls City, turn right onto highway 181 and proceed southeast toward Karnes City and Kennedy.

\section{Location of nearest telephone}

The nearest telephone is located at Saddletramps and Muleskinner Inn on FM791 , which is several miles from the site and may not be readily accessible. A mobile phone must be taken on site visits.

The TAC's health and safety supplement for Falls City will be included in the permanent site file.

\subsection{REPORTABLE INCIDENTS}

The inspection team should be briefed by the GJPO health and safety officer on potential site hazards and other requirements before site inspections or visits. The GJPO Health and Safety Manager's number is (970) 246-6730.

In accordance with DOE Order 5000.3B, Occurrence Reporting and Processing of Operations Information, any accident, injury, or environmental event (e.g., tornado or flood) occurring during the site inspection is a reportable incident. The condition or event must be reported to the GJPO facility manager or designated contact within 8 hours of the occurrence. The GJPO facility manager's 24-hour telephone number for reporting an incident is (970) 2486070. 


\subsection{LIST OF CONTRIBUTORS}

The following individuals contributed to the preparation of this LTSP.

\begin{tabular}{ll}
\hline Name & Contribution \\
\hline E. Artiglia (TAC) & Site Manager, document review \\
C. Silva (TAC) & Document coordination \\
E. Storms (TAC) & Hydrology \\
J. Jackson (TAC) & Geochemistry \\
P. Martinez (TAC) & Real estate \\
L. Ulland, A. Holm (TAC) & Document review \\
J. Lommler (TAC) & Disposal site map review \\
J. Crain (TAC) & Engineering \\
L. Connolly (TAC) & Technical editing, document production \\
WordCenter, Inc. & coordination \\
K. DeGruyter & Word processing \\
\hline
\end{tabular}




\subsection{REFERENCES}

ASP (American Society of Photogrammetry), 1980. Manual of Photogrammetry, fourth edition, American Society of Photogrammetry, Falls Church, Virginia.

BEG (Bureau of Economic Geology), 1992. Hydrogeology and Hydrochemistry of the Falls City Uranium Mine Tailings Remedial Action Project, Karnes County, Texas, Cooperative Agreement No. IAC (92-93)-0389, prepared for the Texas Department of Health, Bureau of Radiation Control, Austin, Texas.

DOE (U.S. Department of Energy), 1995. Site Observational Work Plan for the UMTRA Project Site at Falls City, Texas, May 1995, DOE/AL/62350-157, Rev. O, DOE UMTRA Project, DOE Environmental Restoration Division, Albuquerque, New Mexico.

DOE (U.S. Department of Energy), 1994a. Uranium Mill Tailings Remedial Action Project 1993 Environmental Report, October 1994, DOE/AL/62350-101, DOE UMTRA Project, DOE Environmental Restoration Division, Albuquerque, New Mexico.

DOE (U.S. Department of Energy), 1994b. Baseline Risk Assessment of Ground Water Contamination at the Uranium Mill Tailings Site Near Falls City, Texas, September 1994, DOE/AL/62350-64, Rev. 1, DOE UMTRA Project, DOE Environmental Restoration Division, Albuquerque, New Mexico.

DOE (U.S. Department of Energy), 1993. Licensing Plan for UMTRA Project Disposal Sites, final, September 1993, DOE/AL/62350-9F, DOE UMTRA Project, DOE Environmental Restoration Division, Albuquerque, New Mexico.

DOE (U.S. Department of Energy), 1992a. Guidance for Implementing the UMTRA Project Long-term Surveillance Program, final, September 1992, UMTRA-DOE/AL350125.0000, DOE UMTRA Project, DOE Environmental Restoration Division, Albuquerque, New Mexico.

DOE (U.S. Department of Energy), 1992b. Remedial Action Plan and Site Design for Stabilization of the Inactive Uranium Mill Tailings Site at Falls City, Texas, September 1992, 050520.0000, DOE UMTRA Project, DOE Environmental Restoration Division, Albuquerque, New Mexico.

DOE (U.S. Department of Energy), 1992c. Long-Term Surveillance and Maintenance Program Quality Assurance Program Plan, P-GJPO-152, July 1992, prepared for the U.S. Department of Energy by Chem Nuclear Geotech, Inc., DOE Grand Junction Projects Office, Grand Junction, Colorado.

DOE (U.S. Department of Energy), 1991. Environmental Assessment of Remedial Action at the Falls City Uranium Mill Tailings Site, Falls City, Texas, December 1991, DOE/EA-0468, DOE UMTRA Project, DOE Environmental Restoration Division, Albuquerque, New Mexico. 
DOE (U.S. Department of Energy), 1989. Cooperative Agreement Between the United States Department of Energy and State of Texas, DOE Cooperative Agreement No. DE-FC04-87AL20532, DOE UMTRA Project, DOE Environmental Restoration Division, Albuquerque, New Mexico.

EPA (U.S. Environmental Protection Agency), 1986. RCRA Ground Water Monitoring Technical Enforcement Guidance Document, OSWER Directive 9950.1.

JEG (Jacobs Engineering Group, Inc.), n. d., Albuquerque Operations Manual, Standard Operating Procedures, prepared by Jacobs Engineering Group, Albuquerque, New Mexico, for the DOE UMTRA Project, DOE Environmental Restoration Division, Albuquerque, New Mexico.

MKF (MK-Ferguson), 1995. Falls City, Texas, Draft Completion Report, March 1995, Contract No. DE-AC04-83AL18796, prepared by MKF for the DOE UMTRA Project, DOE Environmental Restoration Division, Albuquerque, New Mexico.

MK (Morrison-Knudsen), 1993. Long-Term Surveillance Plan Subcontract Documents Final Design for Review, July 1993, prepared by MK for the DOE UMTRA Project, DOE Environmental Restoration Division, Albuquerque, New Mexico.

\section{DOE ORDERS}

Order 1324.2A, Records Disposition, September 13, 1988, Office of Information Resources Management, U.S. Department of Energy, Washington, D.C.

Order 5000.3B, Occurrence Reporting and Processing of Operations Information, February 22, 1993, U.S. Department of Energy, Washington, D.C.

Order 5400.1, General Environmental Protection Program, June 29, 1990, U.S. Department of Energy, Environmental Protection Division, Office of Environment, Safety and Health, Washington, D.C.

Order 5480.1B, Environment, Safety and Health (ES\&H) Program for DOE Operations, September 1986, U.S. Department of Energy, Safety Programs Division, Washington, D.C.

Order 5700.6C, Quality Assurance, August 21, 1991, Office of Nuclear Energy and Office of Environment, Safety, and Health, U.S. Department of Energy, Washington, D.C.

\section{FEDERAL REGISTER}

60 FR 2854-2871, Groundwater Standards for Remedial Actions at Inactive Uranium Processing Sites, January 11, 1995. 
55 FR 45591, Custody and Long-Term Care of Uranium and Thorium Mill Tailings Disposal Sites, October 30, 1990.

\section{U.S. CODE}

42 USC $\$ 7901$ et seq., Uranium Mill Tailings Radiation Control Act of 1978. November 8, 1978.

\section{CODE OF FEDERAL REGULATIONS}

10 CFR Part 40, Domestic Licensing of Source Material, U.S. Nuclear Regulatory Commission.

36 CFR Parts 1220-1238, National Archives and Records, Subchapter B - Records Management, National Archives and Records Administration.

40 CFR Part 192, Health and Environmental Protection Standards for Uranium and Thorium Mill Tailings, U.S. Environmental Protection Agency.

40 CFR Part 264, Standards for Owners and Operators of Hazardous Waste Treatment, Storage, and Disposal Facilities, U.S. Environmental Protection Agency.

41 CFR Part 101, Federal Property Management Regulations, General Services Administration. 
ATTACHMENT 1

SITE OWNERSHIP/CUSTODY DOCUMENTATION 


\section{ATTACHMENT 1}

\section{SITE OWNERSHIP/CUSTODY DOCUMENTATION}

\section{GENERAL}

The Falls City disposal site in Falls City, Texas, was acquired by the state of Texas as required under the Uranium Mill Tailings Radiation Control Act (UMTRCA), as amended.

The site originally comprised 746.13 acres. Upon completion of remedial action, the final disposal site acreage was partitioned out of the original 746.13 acres by the state of Texas in agreement with the U.S. Department of Energy and based on a survey dated 11 November 1994 (Plate 1).

\section{DOCUMENTATION OF ACQUISITION}

A. Legal description of Disposal Site

Tract "B," 231.15 Acres

Samuel A. J. Mays Survey A-212

Karnes County, Texas

BEING a tract of land containing 231.15 acres, more or less, out of the Samuel A. J. Mays Survey A-212, Karnes County, Texas and being comprised of 34.32 acres out of that 249.88 acre tract conveyed by Jimmie E. Nix to the Texas Department of Health by Warranty Deed dated March 6, 1991, recorded in Volume 618, Page 615 of the Deed Records of Karnes County, Texas and all of that 43.68 acre tract conveyed by Solution Engineering, Inc. to the Texas Department of Health by Warranty Deed dated March 13, 1991, recorded in Volume 618, Page 422 of said Deed Records and 153.15 acres out of that 186.59 acre tract conveyed by Solution Engineering, Inc. to the Texas Department of Health by Warranty Deed dated April 27, 1990, recorded in Volume 597, Page 617 of said Deed Records and being more particularly described as follows:

BEGINNING at a 5/8" iron rod found in a fence corner in the northwest line of said 249.88 acre tract and the southeastern boundary of a $40 \mathrm{ft}$. wide private road for the west corner of the tract herein described, also being the northerly north corner of a 514.98 acre tract " $A$ " surveyed this date, whence a $5 / 8$ "' iron rod found at the west corner of said 249.88 acre tract at the north corner of a called 180.10 acres tract conveyed by Rodney Seidel, et ux, to Concord Oil Company by deed dated November 26, 1982, recorded in Volume 532, Page 563 of said Deed Records bears S $50^{\circ} 47^{\prime}$ W 2,728.19 ft.;

THENCE N 50 47' E $667.69 \mathrm{ft}$. with the fence and the northwest line of said 249.88 acre tract and the southeastern boundary of said private road to a $5 / 8^{\prime \prime}$ iron rod found at the north corner of said 249.88 acre tract and the west corner of said 43.68 acre tract for an interior corner of this tract; THENCE N 50 $52^{\prime}$ E 2,161.51 ft. continuing with the fence and the southeastern boundary of said private road and 
the northwest line of said 43.68 acre tract to a concrete right-of-way monument found at the intersection of same with the southwestern boundary of Texas Farm to Market Highway No. 1344 at the north corner of said 43.68 acre tract for the north corner of this tract;

THENCE with the fence along the southwestern boundary of said F.M. Highway No. 1344 and the northeast line of said 43.68 acre tract and the northwest line of said 186.59 acre tract with the following seven (7) calls:

1. S $82^{\circ} 25^{\prime}$ E $148.20 \mathrm{ft}$. to a concrete right-of-way monument found at an angle to the right in same, being a point in a curve to the left, whence the center of said

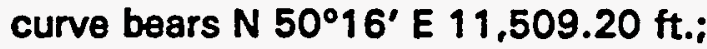

2. $154.28 \mathrm{ft}$. with the arc of said curve having a central angle of $00^{\circ} 46^{\prime} 05^{\prime \prime}$ and a radius of $11,509.20 \mathrm{ft}$. to a concrete right-of-way monument found at the point of tangency for a corner of this tract, whence the center of said curve bears $\mathrm{N}$ $49^{\circ} 30^{\prime}$ E 11,509.20 ft.;

3. S $40^{\circ} 30^{\prime}$ E $870.66 \mathrm{ft}$. to a concrete right-of-way monument found at the point of curvature of a curve to the right for a corner of this tract, whence the center of said curve bears S $49^{\circ} 30^{\prime} \mathrm{W} 11,459.20 \mathrm{ft}$.;

4. $308.60 \mathrm{ft}$. with the arc of said curve having central angle of $01^{\circ} 32^{\prime} 35^{\prime \prime}$ and a radius of $11,459.20 \mathrm{ft}$ to a $5 / 8^{\prime \prime}$ iron rod found at the point of tangency for a corner of this tract, whence the center of said curve bears $S 51^{\circ} 03^{\prime} \mathrm{W} 11,459.20$ ft.;

5. S $38^{\circ} 57^{\prime}$ E $1,568.39 \mathrm{ft}$. to a concrete right-of-way monument found at an angle to the right in same for a corner of this tract;

6. S $41^{\circ} 31^{\prime} E 194.85 \mathrm{ft}$. to a concrete right-of-way monument found at an angle to the left in same for a corner of this tract; and

7. S $38^{\circ} 34^{\prime} \mathrm{E} 244.98 \mathrm{ft}$. to a $5 / 8^{\prime \prime}$ iron rod found in a fence corner at the east corner of said 186.59 acre tract for the east corner of this tract and the lower north corner of said Tract "A". also being the north corner of a 265.98 acre tract conveyed by Corpus Christi National Bank (formerly MBank) to the Texas Department of Health by Warranty Deed dated February 8, 1991, recorded in Volume 616, Page 770 of said Deed Records;

THENCE $S 51^{\circ} 24^{\circ} \mathrm{W}$ with the fence and a southeast line of said 186.59 acre tract and the lower northwest line of said Tract " $A$ " and a northwest line of said 265.98 acre tract, at 1,671.40 ft. pass an exterior corner of said 265.98 acre tract and an interior corner of said 186.59 acre tract, at $2,770.73 \mathrm{ft}$. crossing a portion of said 186.59 acre tract pass an interior corner thereof and the east corner of said 249.88 acre tract, and continuing with the fence and a northwest line of said 186.59 acre tract and a southeast line of said $\mathbf{2 4 9 . 8 8}$ acre tract for a total distance of $2,821.22 \mathrm{ft}$. to a 5/8" steel fence post in concrete found at an exterior corner of 
said 186.59 acre tract and an exterior corner of said 249.88 acre tract for an exterior corner of this tract and an interior corner of said Tract "A";

THENCE S $51^{\circ} 11^{\prime} \mathrm{W} 100.00 \mathrm{ft}$. with the fence and a northwest line of said Tract "A" and said 265.98 acre tract and a southeast line of said 249.88 acre tract to a $5 / 8$ " iron rod found at an interior corner of said Tract " $A$ " for the south corner of this tract;

THENCE $N 39^{\circ} 45^{\prime} \mathrm{W} 3,421.96 \mathrm{ft}$. with the fence and a northeast line of said Tract "A" to the PLACE OF BEGINNING.

The bearings recited hereon are based on the called bearing between two (2) 5/8" iron rods found on the southeast line of said 265.98 acre tract conveyed by Corpus Christi National Bank (formerly MBank) to the Texas Department of Health by Warranty Deed dated February 8, 1991, recorded in Volume 616. Page 770 of said Deed Records (called S $51^{\circ} 14^{\prime}$ W). Distances are surface.

\section{B. Recorded Deed.}

The deed is not recorded yet. 
ATTACHMENT 2

NRC CONCURRENCE AND LICENSING DOCUMENTATION

(To be provided when received) 
ATTACHMENT 3

SITE INSPECTION PHOTO LOG 


\section{SITE INSPECTION PHOTO LOG}

Site: Site Activity:

Date: Time of Day: From to

Weather Conditions:

Roll Number: Film Type: Number of Exposures

\section{Photo Number}

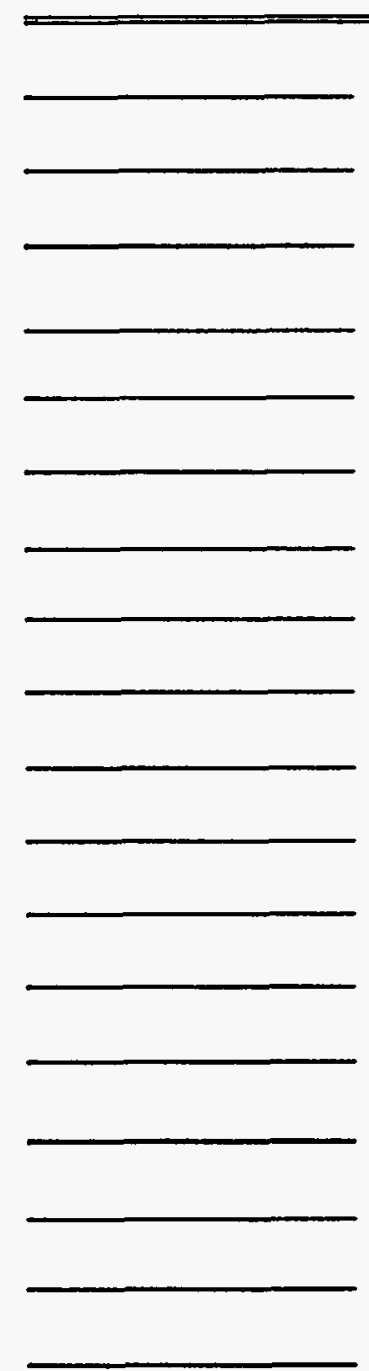

\section{Location}

Description 


\section{SITE INSPECTION PHOTO LOG (CONT.)}

Site

Date

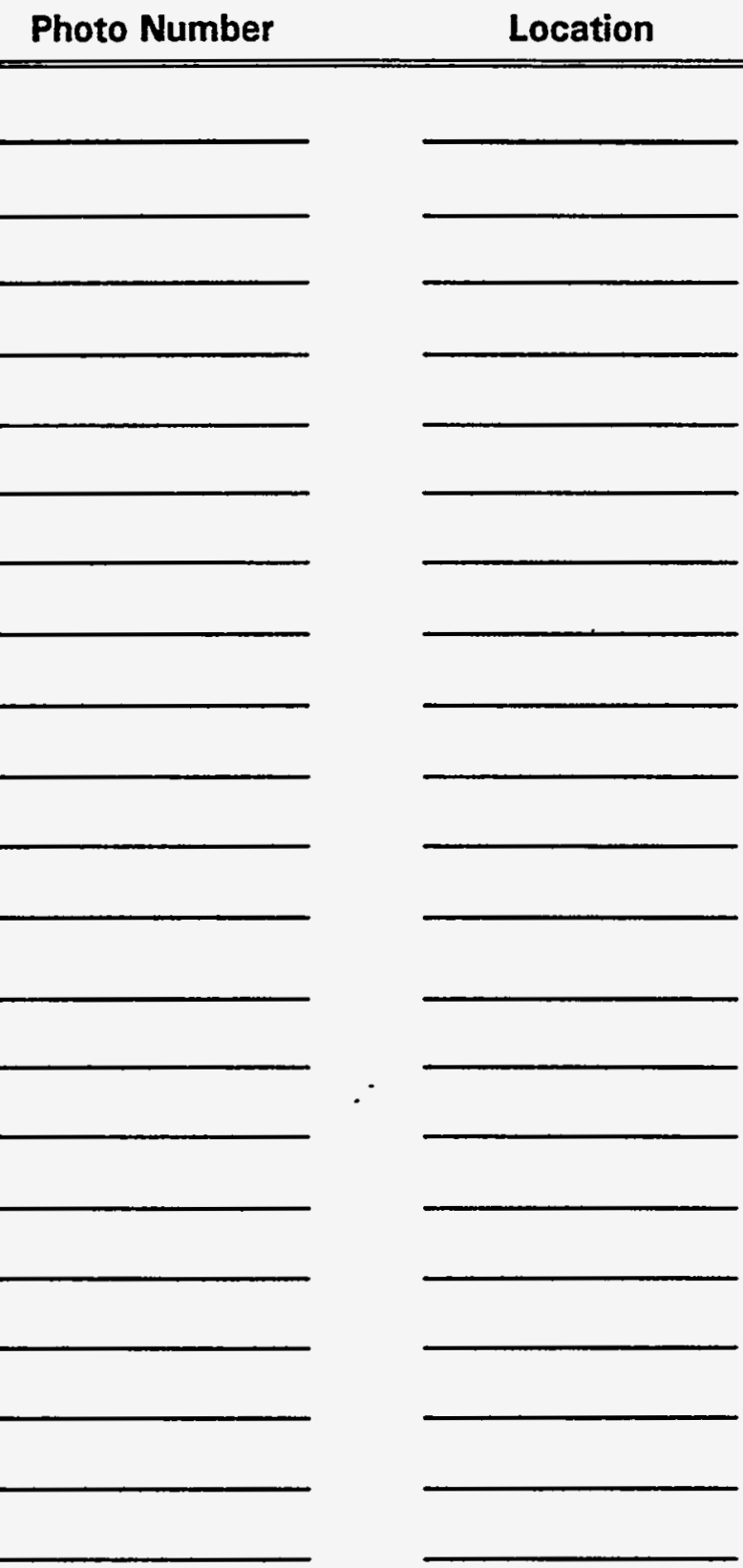

Photographer:

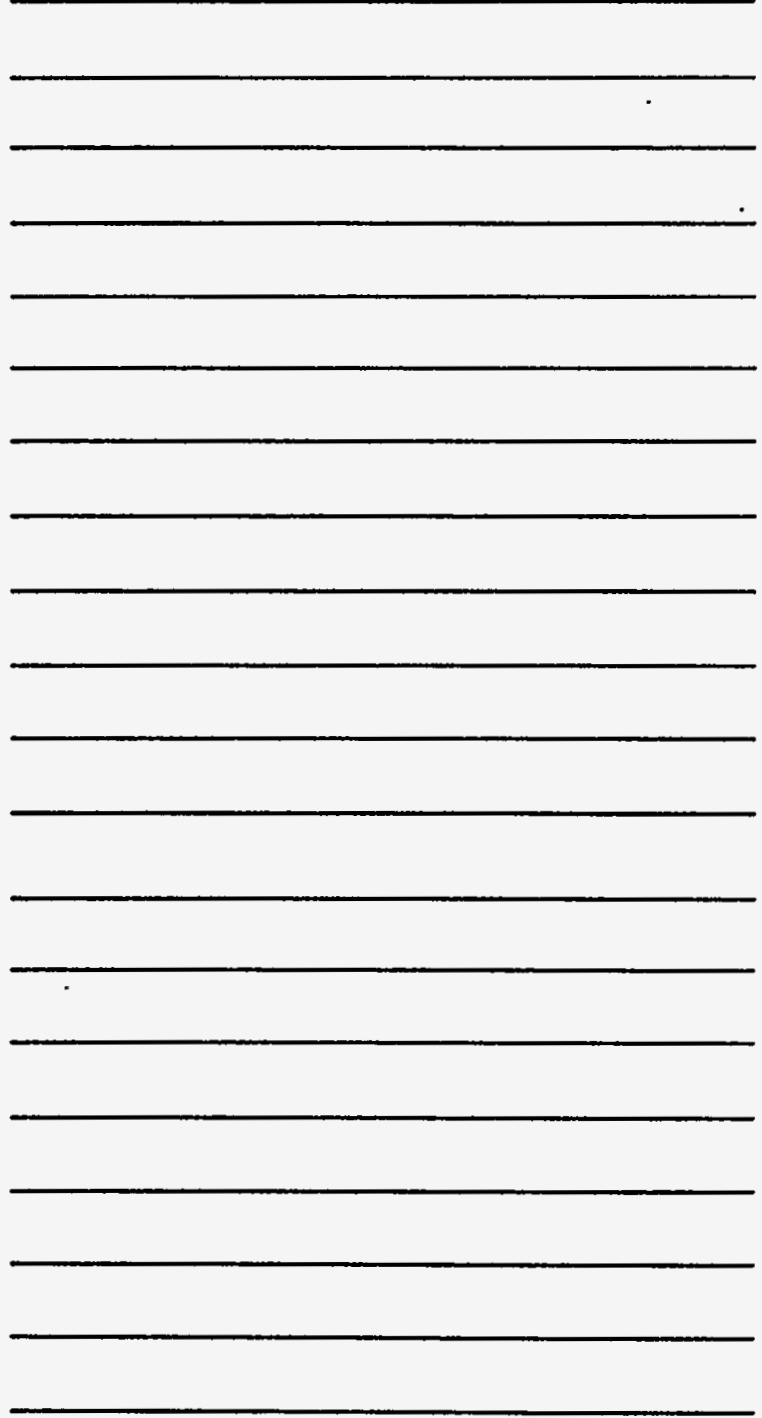


ATTACHMENT 4

SITE INSPECTION CHECKLIST 


\section{SITE INSPECTION CHECKLIST FOR THE FALLS CITY, TEXAS URANIUM MILL TAILINGS DISPOSAL SITE}

Date of Last Inspection:

Responsible Agency": DOE Grand Junction Projects Office

Reason for Last Inspection:

Address: P.O. Box 2567, Grand Junction, Colorado 81502-2567

Responsible Agency Official:

Inspection Start Date and Time:

Weather Conditions at Site:

Inspection Completion Date and Time:

Chief Inspector:

Name Title Organization

Assistant Inspector:

Name Title Organization

\section{A. GENERAL INSTRUCTIONS}

1. All checklist items must be completed and detailed comments made to document the results of the site inspection. The completed checklist is part of the field record of the inspection. Additional pages should be used, as necessary, to ensure that a complete record is made. Attach the additional pages and number all pages upon completion of the inspection.

2. Inspectors are to provide an up-to-date résumé or vitae for inclusion in the inspection report.

3. Any checklist line item marked by an "* "that is checked by an inspector must be fully explained or an appropriate reference to previous reports provided. The purpose of this requirement is to provide a written explanation of inspector observations and the inspector's rationale for conclusions and recommendations. Explanations are to be placed on additional attachments and cross-referenced appropriately. Explanations, in addition to narrative, will take the form of sketches, measurements, and annotated site atlas overlays.

4. The site inspection is a walking inspection of the entire site, including the perimeter and sufficient transects to be able to inspect the entire surface and all features specifically described in this checklist. Every monument, site marker, sign, monitoring well, and erosion control marker will be inspected.

5. A set of color print $35-\mathrm{mm}$ photographs is required. Sufficient photographs will be

'Responsibility for site inspections assigned by DOE UMTRA Project, Albuquerque, to DOE Grand Junction Projects Office. November 6 , 1990. 
taken to compare to baseline photographs and determine if there are any significant differences in site appearance. In addition, all anomalous features or new features (such as changes in adjacent area land use) are to be photographed. A photo log entry will be made for each photograph taken.

6. Field notes taken to assist in completion of this checklist will become part of the inspection record. No form is specified; the field notes must be legible and in sufficient detail to enable review by succeeding inspectors and the responsible agency.

B. PREPARATION (to be completed prior to site visit)

1. License (includes Long-Term Surveillance and Maintenance Plan) reviewed.

2. Site as-buitt plans reviewed and base map with copies of the following site atlas overlays obtained:

a. Adjacent off-site features and land use; fences, gates, and signs; access roads and paths.

b. Survey monuments, boundary markers, site markers, aerial photo ground controls, ground photo locations.

c. Monitoring wells, site drainage, diversion channels.

d. Planned inspection transects and vegetation cover.

e. Others.

These overlays will be used to identify site features and record, as appropriate, field data.

3. Previous inspection reports reviewed.

a. Were anomalies or trends in modifying processes detected on previous inspections?

b. Was a Phase II inspection conducted?

c. Was custodial maintenance performed?

d. Was contingency repair work done as a result of the Phase II inspection? 
4. Site custodial maintenance and contingency repair records reviewed.

a. Has site contingency repair resulted in a change from as-built conditions?

b. Are reviewed as-builts available that reflect contingency repair changes?

5. If required, adjacent property entry approval obtained (attach signed access agreement).

6. Aerial photos, if taken since last inspection, reviewed. For each set, enter date taken, scale, and if interpreted.

\section{Set}

Date

1.

2.

3.
Scale

Yes
Interpreted

Yes No

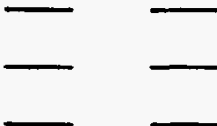

7. Were any of the following suggested by examination

No of aerial photographs? (If yes, give photo set date and indicate if item noted by interpreter or inspector):
a. Intrusion by man?
b. Intrusion by animals?
c. Channelized erosion on slopes?
d. Change in area drainage?
e. Landslides?
f. Creep on slopes?
g. Obstruction of diversion channels?
h. Bank erosion of diversion channels?
i. Seepage? 
j. Cracking?

k. Change in vegetative cover?

I. Displacement of fences, site markers, boundary markers, or monuments?

m. Change in adjacent land use?

n. Evidence of tailings exposure or transport?

8. From as-builts, or subsequent inspection reports, note distance and azimuth from designated site location, such as a monument, to adjacent off-site features that could eventually affect integrity of site.
Off-site feature
Site monument no.
Distance
Azimuth

1.

2.

3.

9. Assemble and check out the following equipment, as needed, to conduct inspections:

a. Cameras, film, and miscellaneous support equipment.

b. Binoculars.

c. Tape measure.

d. Optical ranging device.

e. Brunton compass.

f. Photo scale stick.

g. Erasable board.

h. Plant press, plastic bags for vegetation.

i. Keys to locks.

j. Bolt cutters.

k. Hand lens.

I. Clipboard.

m. Others. 


\section{SITE INSPECTION}

1. Adjacent off-site features (within 0.25 mile [0.4 meter] of site boundary)

a. Have there been any changes in use of adjacent areas (grazing, construction, agriculture)?

b. Are there any new roads or trails?

c. Has there been a change in the position of nearby stream channels?

d. Has there been headward erosion of nearby gullies?

e. Are there new drainage channels?

f. Others?

2. Access roads and paths, fences, gates, and signs.

a. Is there a break in the fence?

b. Have any posts been damaged or their anchoring weakened?

C. Is there evidence of erosion or digging beneath the fence?

d. Does the gate show evidence of tampering or damage?

e. Is there any evidence of human intrusion?

f. Is there any evidence of large animal intrusion?

g. Have any signs been damaged or removed? (Number of signs replaced:

h. Are access roads and paths passable?

i. Others? 
3. Monuments and other permanent features.

a. Have the survey or boundary monuments been defaced or disturbed?

b. Have the site markers been disturbed by man or natural processes?

c. Do natural processes threaten the integrity of any monument or site marker?

d. Others?

4. Crest.

Yes No

a. Is there evidence of uneven settling?

(depressions, scarps)

b. Is there cracking?

c. Has the outer cover layer been breached?

d. Is there evidence of erosion?

1) By water? (rills, rivulets)

2) By wind? (pedestal rocks, ripple marks)

e. Is the vegetation cover as described in the as-builts?.

f. Is there evidence of animal burrowing?

g. Others?

5. Slopes.

Yes No

a. Is there evidence of gradual downslope movement (creep)? (terraces, deflection of plants)

b. Is there cracking?

c. Can depressions or bulges on the slope be seen? 
d. Has the outer cover layer been breached?

e. Is there evidence of erosion:

1) By water?

2) By wind?

f. Has water runoff become channelized? (rivulets, gullies)

g. Is there evidence of seepage? (moisture, color, vegetation)

h. Has the vegetation cover changed significantly since the last inspection?

i. Is there evidence of animal burrowing?

j. Is there evidence of deterioration of riprap or gravel cover?

k. Others?

6. Periphery (within site boundaries).

Yes No

a. Is there evidence of seepage such as wet areas or localized change of vegetation?

b. Is there evidence of sediment transport from the tailings pile by water or wind?

c. Is the vegetative cover as described in the as-builts?

d. Is the drainage as described in the as-builts?

e. Others? Burrowing animals; erosion.

7. Diversion channels.

Yes No

a. Is there evidence of bank erosion? 
b. Has the integrity of riprap structures been disturbed by people or natural processes?

c. Is there evidence of channel erosion?

d. Is there evidence of sedimentation in the channel?

e. Is the channel obstructed in any way?

f. Is there any evidence that the diversion channels are not performing their function?

g. Others?

8. Photography.

a. Have all photos required by the site atlas photo overlay been taken?

b. Has a photo log sheet been prepared for each roll of film exposed?

c. Number of rolls of film exposed:

d. Others?

9. Monitor wells.

a. Have any monitor wells been disturbed by man or natural processes?

b. Does any natural process threaten the integrity of any monitor well?

c. Are all monitor wells capped and locked?

d. Others? 


\section{FIELD CONCLUSIONS}

1. Is there an imminent hazard to the integrity of the

Yes № tailings pile? (Immediate report required)

Person

Agency to whom report made:

2. Are more frequent Phase I inspections required?

3. Are existing contingency repair actions satisfactory?

4. Is a Phase II inspection required?

5. Is a contingency report or custodial maintenance required?

6. Rationale for field conclusions are documented as the text of this report.

\section{E. CERTIFICATION}

I have conducted a prelicensing inspection of the Falls City, Texas, uranium mill tailings site in accordance with the procedures of the license (includes the site surveillance plan) as recorded on this checklist, attached sheets, field notes, photo log sheets, and photos. 
ATTACHMENT 5

AGENCY NOTIFICATION AGREEMENTS 


\section{DRAFT}

Terry Schmidt

Karnes County Sheriff

113 W. Panna Maria

Karnes City, Texas 78118

Dear Mr. Schmidt:

The U.S. Department of Energy (DOE) Uranium Mill Tailings Remedial Action Project is requesting notification in the event of any unusual activities or events in Karnes County, Texas, or around the Falls City disposal site located 46 miles (74 kilometers [km]) southeast of San Antonio, and 8 miles $(13 \mathrm{~km})$ southwest of Falls City, Texas.

The purpose of the notification request is to assist the DOE in surveying and maintaining the integrity of its disposal site and to ensure public safety.

If during the course of routine activities, anything out of the ordinary is observed by your staff or reported to your office, we would appreciate notification to the DOE Grand Junction Projects Office's 24-hour phone line at (970) 248-6070. If the notification request discussed above is agreeable to you, please sign and return the attached reply letter for our records as soon as possible.

Should you have any questions, please contact me at (505) 845-5637. Thank you for your attention in this matter.

Woody Woodworth

Project Site Manager

Environmental Restoration Division

U.S. Department of Energy

\section{Enclosure}

cc: w/o enclosure

EArtiglia (TAC)

SHamp (ERD)

CJones (GJPO)

MHansen (TAC)

CSilva (TAC)

JVirgona (GJPO) 


\section{DRAFT}

Woody Woodworth

Project Site Manager

Environmental Restoration Division

U.S. Department of Energy

P.O. Box 5400

Albuquerque, NM 87185

Dear Mr. Woodworth:

This letter is to concur with the U.S. Department of Energy (DOE) request for notification as set forth in the DOE's letter. As requested in your letter, this office will contact the DOE's Grand Junction Projects Office at (970) 248-6070 if any unusual event or anomaly is observed or reported at the Falls City disposal site, Falls City, Texas.

Sincerely,

Mr. Terry Schmidt

Karnes County Sheriff

cc: EArtiglia (TAC)

SHamp (ERD)

CJones (GJPO)

MHansen (TAC)

CSilva (TAC)

JVirgona (GJPO) 


\section{DRAFT}

Dr. Joe Friday

Cooperative Program Manager

National Weather Service

2090 Airport Road

New Braunfels, Texas 78130

Dear Dr. Friday:

The U.S. Department of Energy (DOE) Uranium Mill Tailings Remedial Action Project is requesting notification in the event of issuance of flash flood or tornado warnings in Karnes County, Texas. We would appreciate notification to the DOE Grand Junction Projects Office's 24-hour phone line at (970) 248-6070 within 8 hours of issuance of a warning or episode of warnings.

The purpose of this warning is to assist the DOE in surveying and maintaining the integrity of its disposal site located 46 miles (74 kilometers [km]) southeast of San Antonio and 8 miles $(13 \mathrm{~km})$ southwest of Falls City, Texas.

If the notification request discussed above is agreeable to you, please sign and return the enclosed reply letter for our records as soon as possible.

Should you have any questions, please contact me at (505) 845-5637.

Sincerely,

Woody Woodworth

Project Site Manager

Environmental Restoration Division

U.S. Department of Energy

Enclosure

cc: w/o enclosure

EArtiglia (TAC)

SHamp (ERD)

CJones (GJPO)

MHansen (TAC)

CSilva (TAC)

JVirgona (TAC) 


\section{DRAFT}

Woody Woodworth

Project Site Manager

Environmental Restoration Division

U.S. Department of Energy

P.O. Box 5400

Albuquerque, New Mexico 87185

Dear Mr. Woodworth:

This letter is to concur with the U.S. Department of Energy (DOE) request for notification as set forth in the DOE's letter. As requested in your letter, this office will contact the Grand Junction Projects Office at (970) 248-6070 in the event of issuance of a flash flood or tornado warning in Karnes County, Texas.

Sincerely,

Dr. Joe Friday

Cooperative Program Manager

National Weather Service

cc: EArtiglia (TAC)

SHamp (ERD)

CJones (GJPO)

MHansen (TAC)

CSilva (TAC)

JVirgona (GJPO) 


\section{IN UPDC}

\section{National Earthquake Information Center}

\section{World Data Center A for Seismology}

Director

(303) $236-1510$

Research

(303) 236-1506
C.S. Geological Survey

Box 25046, DFC. MS-967

Deqver. Colorado 80225 USA

Telex: (WLTCO) 5106014123ESL [D
Operations

(303) 236-1500

- QED

(800) 358-2663

Clinton C. Smythe

Engineering and Construction Group Leader

Uranium Mill Tailings Remedial Action

Project Office

2155 Louisiana NE, Suite 4,000

Albuquerque, NM 87110

Dear ivir. Smythe:

This letter is to confirm that the DOE Grand Junction Projects Office (24-hour phone line, (303) 248-6070 has been added to our notification list for the occurrence of earthquakes near the following locations:

\begin{tabular}{|l|l|l|}
\hline Disposal Site & Latitude & Longitude \\
\hline COLORADO & & \\
\hline Durango (Bodo Canyon) & $\mathrm{N} 37.15$ & W107.90 \\
\hline Grand Junction & $\mathrm{N} 38.91$ & W108.32 \\
\hline Gunnison (Landfill) & $\mathrm{N} 38.51$ & W106.85 \\
\hline Maybell & $\mathrm{N} 40.55$ & W107.99 \\
\hline Naturita (Dry Flats) & $\mathrm{N} 38.21$ & W108.60 \\
\hline Rifle (Estes Gulch) & $\mathrm{N} 39.60$ & W107.82 \\
\hline Slick Rock (Burro Canyon) & $\mathrm{N} 38.05$ & W108.87 \\
\hline IDAHO & & \\
\hline Lowman & N44.16. & W115.61 \\
\hline NEW MEXICO & & \\
\hline Ambrosia Lake & N35.41 & W107.80 \\
\hline NORTHDAKOTA & & \\
\hline Bowman & N46.23 & W103.55 \\
\hline OREGON & & \\
\hline Lakeview (Collins Ranch) & N42.2 & W120.3 \\
\hline PENNSYLVANIA & & \\
\hline Canonsburg & N40.26 & W80.25 \\
\hline Burrell VP & N40.62 & W79.65 \\
\hline TEXAS & & \\
\hline Falls City & N28.91 & W98.13 \\
\hline UTAH & & \\
\hline Mexican Hat & N37.10 & W109.85 \\
\hline Salt Lake City (Clive) & N40.69 & W113.11 \\
\hline
\end{tabular}




\section{National Earthquake Information Center.}

World Data Center A for Seismology

Director

(303) 236-1510

Research

(303) 236-1506
U.S. Geological Survey

Box 25046, DFC, MS-967

Denver, Colorado 80225 USA

Telex: (WUTCO) 5106014123ESL UD
Operations

(303) 236-1500

QED

(800) $358-2663$

Clinton C. Smythe

$-2-$

We have entered the following selection criteria into our notification program:

1. Any earthquake of magnitude 3.0 or greater, within 0.3 degrees (about 20 miles) of any site shown above, or

2. Any earthquake of magnitude 5.0 or greater, within 1.0 degrees (about 70 miles) of any site shown above. .

Sincerely,

Buace wo. Preageave

Bitice Presgrave

U.S. Geological Survey

National Earthquake Information Center

P.O. Box 25046

Mail Stop 967

Denver Federal Center

Denver, Colorado 80225

Please address future comespondonce to Stuart Koyanagi at the above address. I have moved to a different project.

Thank you + best regards,

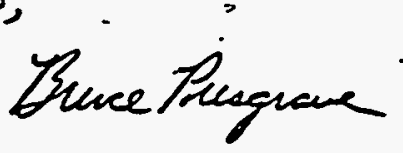




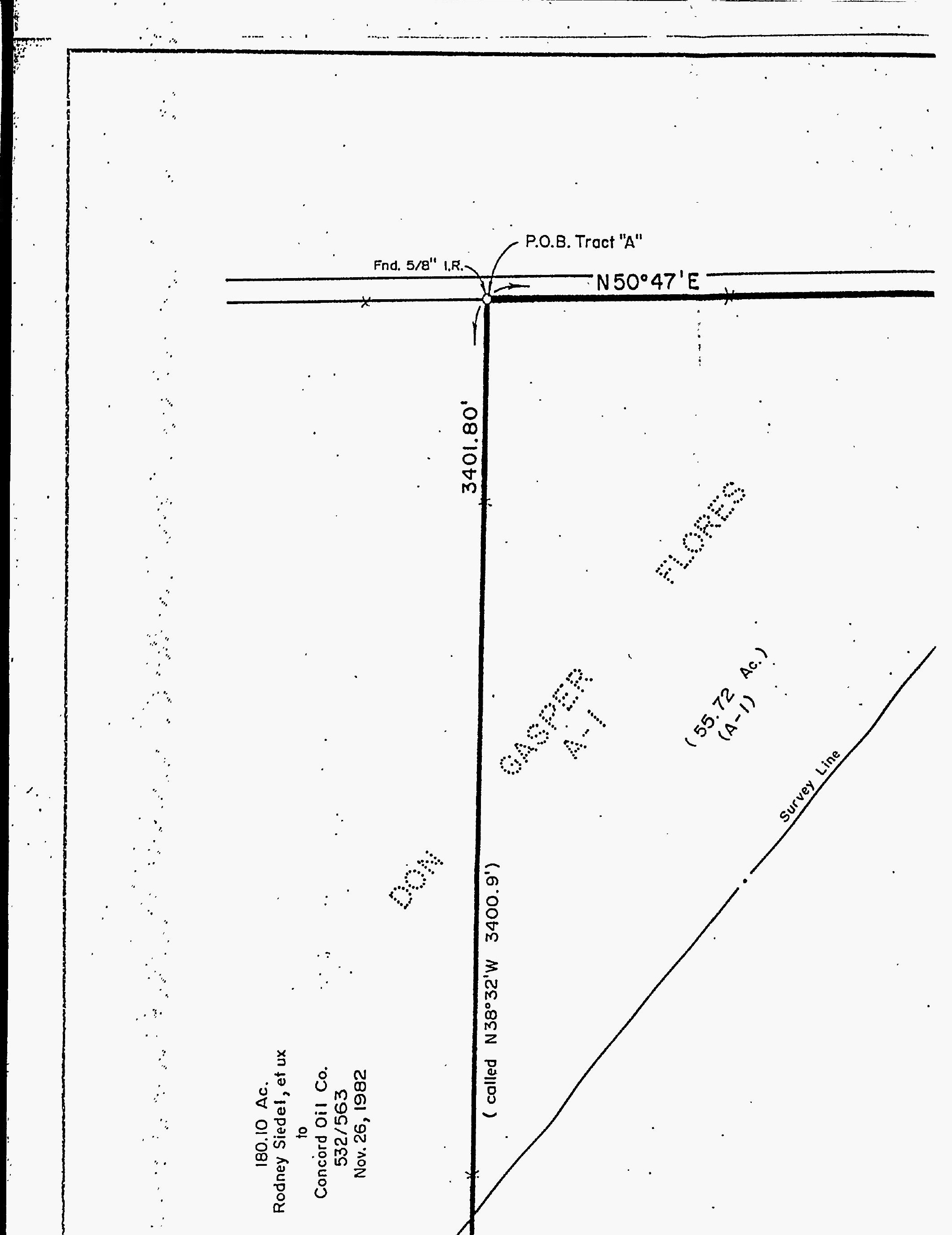




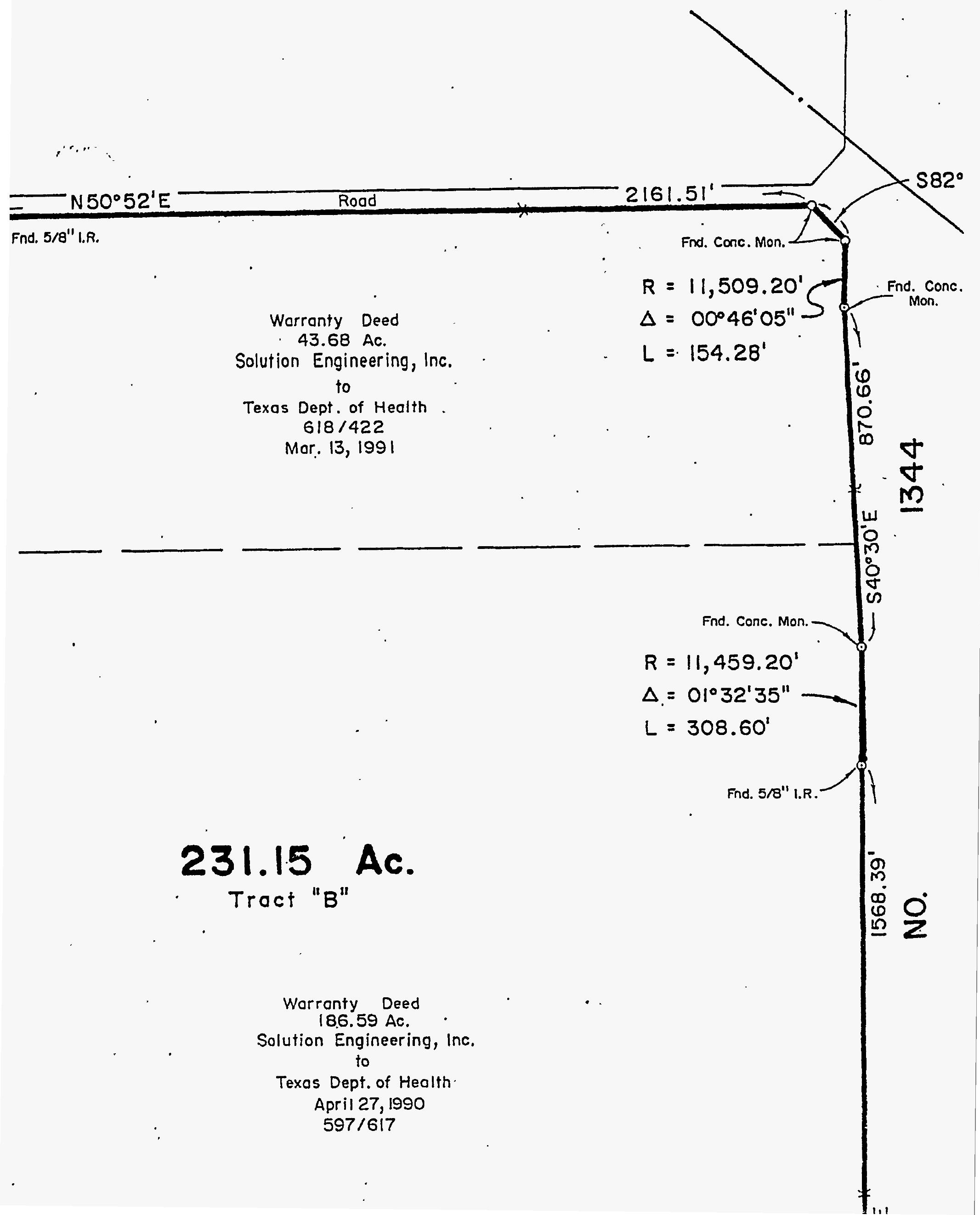




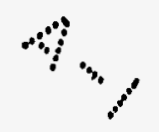

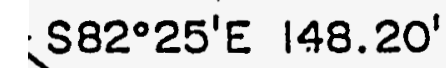

2
7
$j$
7

J. Conc.

Mon.

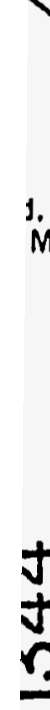

i 


$$
\text { I }
$$




$$
\text { F }
$$





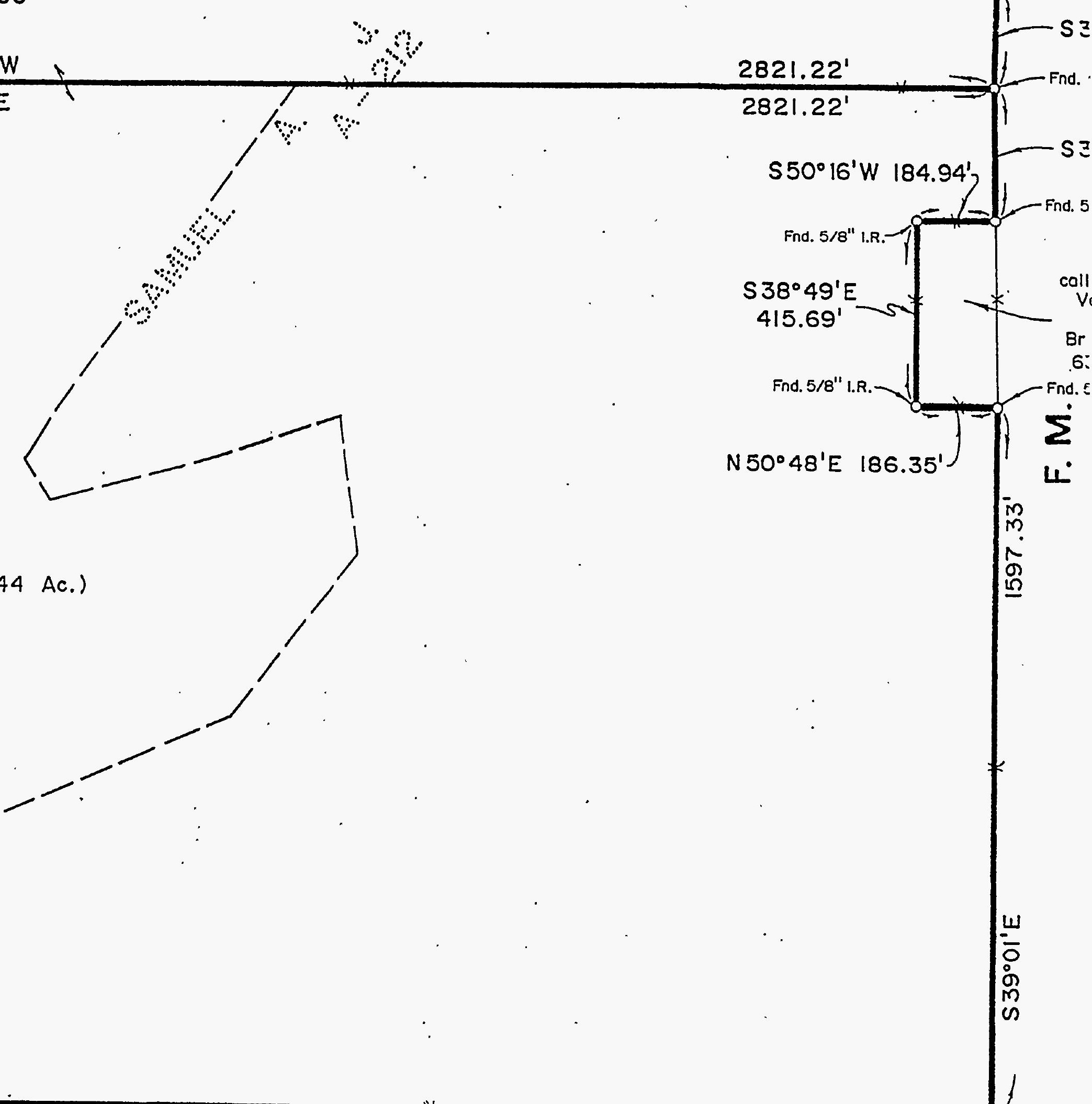




\section{PARTITION OF 746.13 ACRE TRA out of}

$-S 41^{\circ} 3 I^{\prime} E^{\prime} 194.85^{\prime}$

$S 38^{\circ} 34^{\prime} E \quad 244.98^{\prime}$

DON GASPER FLORES GR، "nd. $5 / 8^{\prime \prime}$ I.R.

SAMUEL A. J. MAYS SURVE KARNES COUNTY, TE

nd. 5/8" I.R.

colled 2.00 Ac.Tr.

Verona Dorris

to

Bruce M. Tilley, et ux

$635 / 615-12 / 1 / 92$

=nd. 5/8" I.R.

Note: The bearings shown hereon ore bosed on the col bearing between two (2) $5 / 8^{\prime \prime}$ iron rods found on southeast line of a 265.98 acre tract, recorded Volume 616, Page 770 of the Deed Records of $r$ County, Texas. (Colled $551^{\circ} 14^{\prime} \mathrm{W}$ ) Distances

State of Texos I

County of Bee I

I hereby certify that thi.
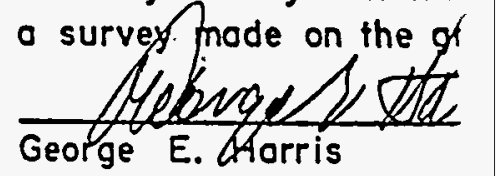

Registered Professional No. $826^{\circ}$ 


\section{PARTITION OF \\ 746.13 ACRE TRACT \\ out of}

GASPER FLORES GRANT A-I

IL A. J. MAYS SURVEY A-212

KARNES COUNTY, TEXAS

e: The bearings shown hereon are bosed on the colled bearing between two (2) $5 / 8$ "iron rods found on the southeast line of o 265.98 ocre troct, recorded in Volume 616, Page 770 of the Deed Records of Karnes County, Texas. (Called $551^{\circ} 14^{\prime} \mathrm{W}$ ) Distances are surface.

State of Texos I

County of Bee I

I hereby certify that this plat accurately represents a survey. frode on the ground under my direction. George E. A Aorris

Registered Professional Land Surveyor No. $826^{\circ}$

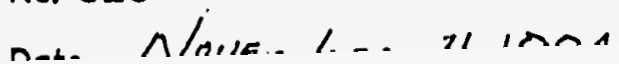

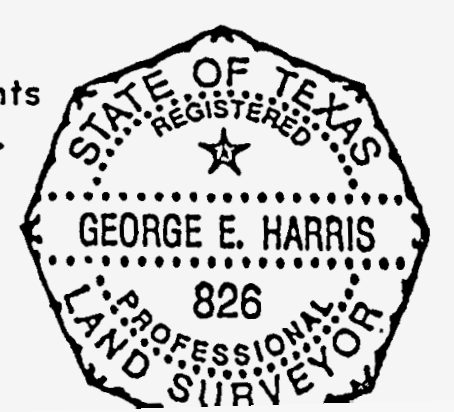




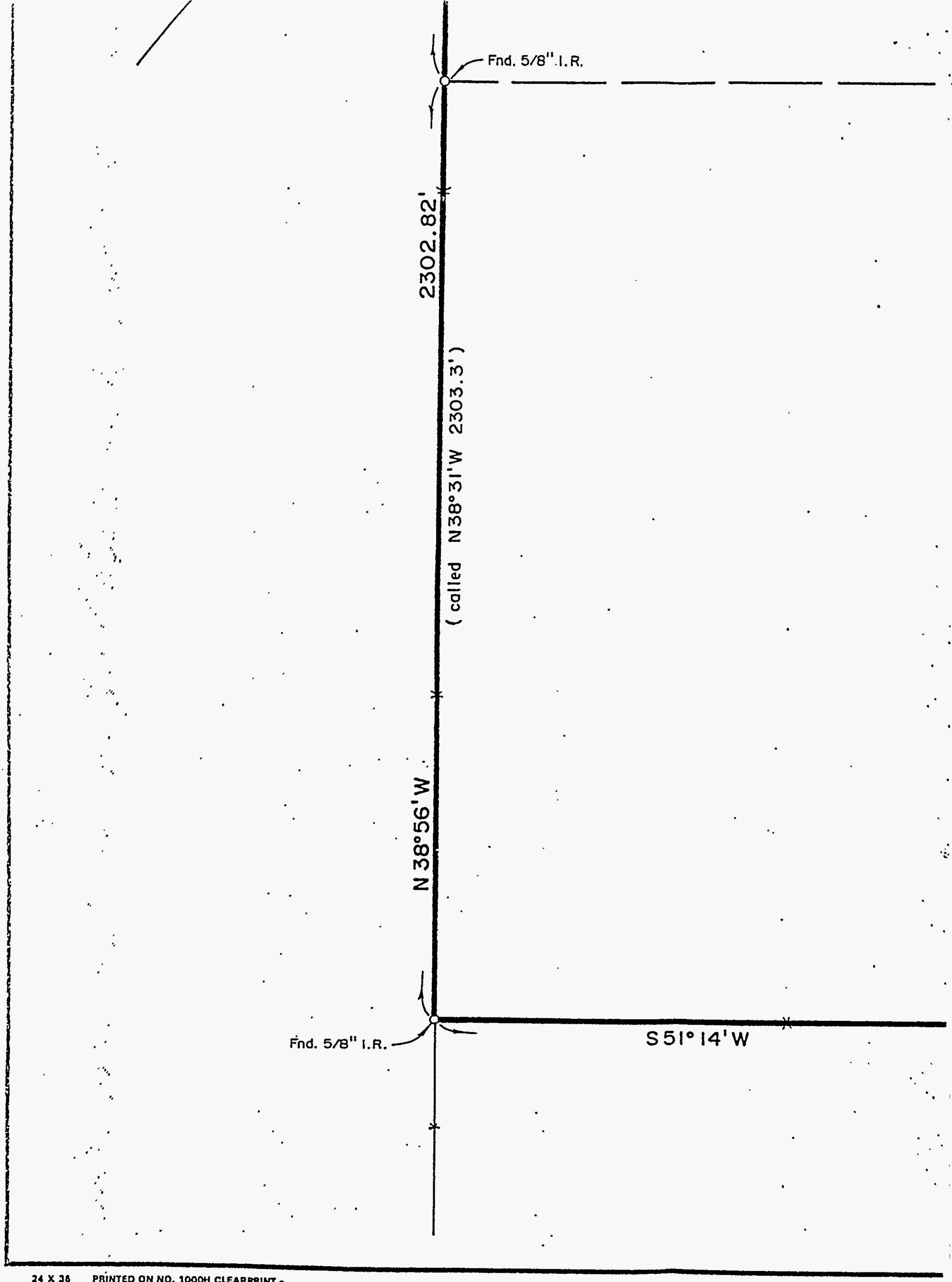




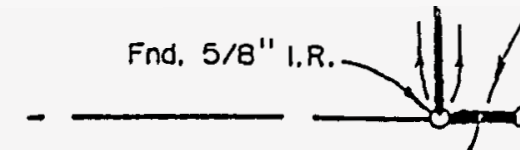
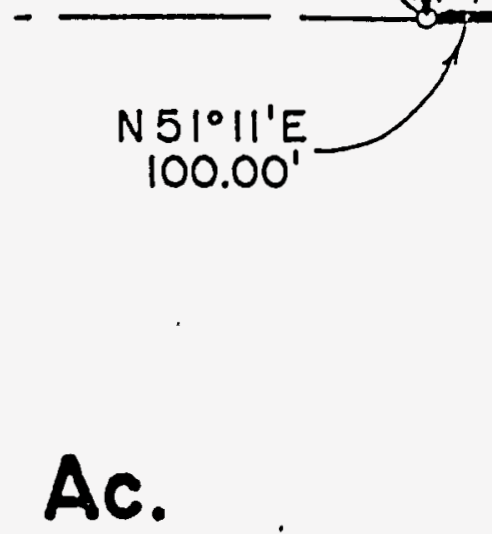

\section{Ac.}

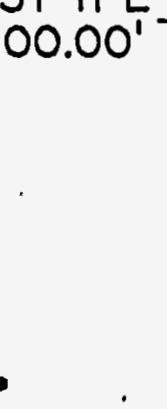

1 Fnd. Fence Post

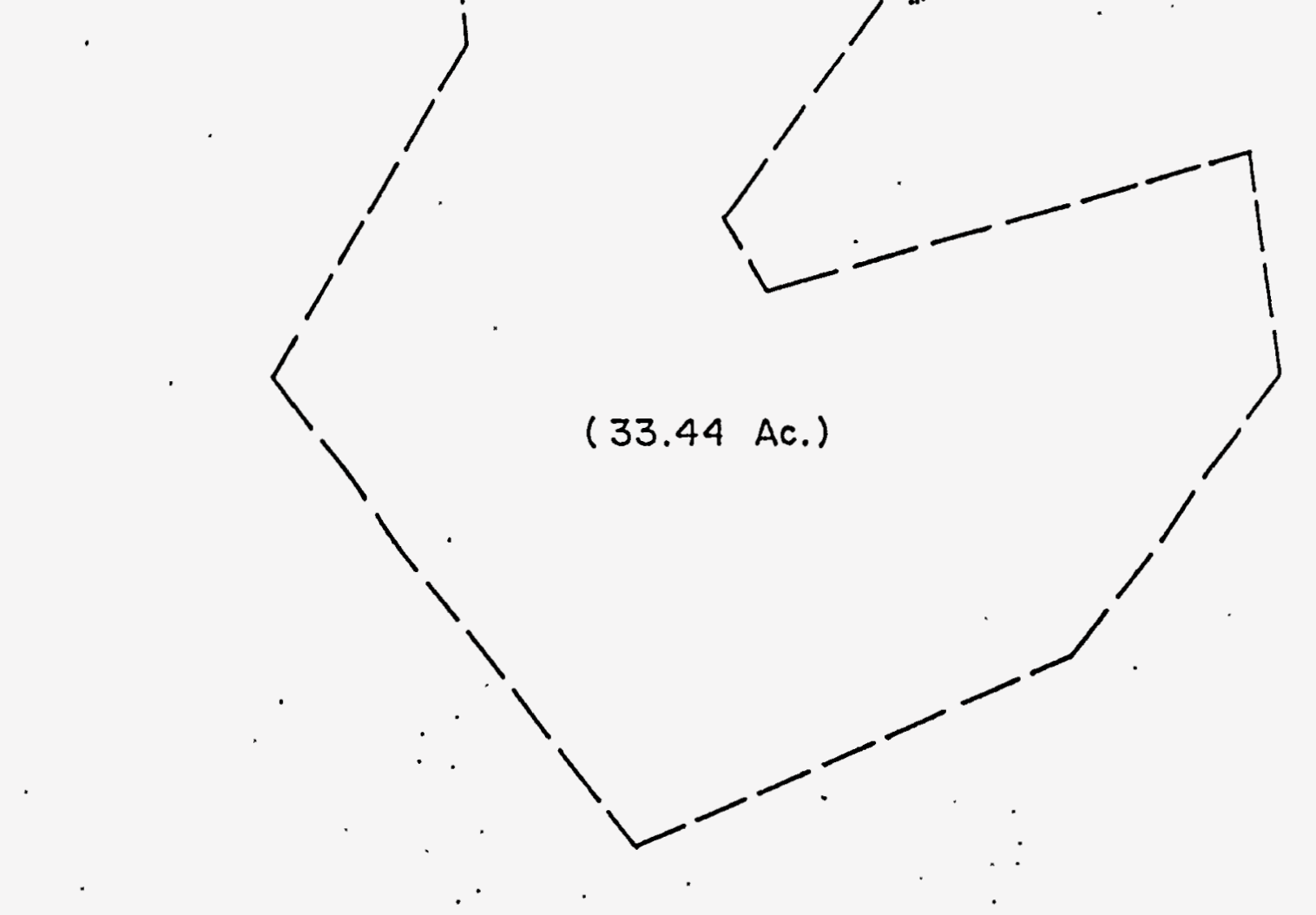

j.73 Ac. (called 250.00 Ac.)

Korzekwa to Thereso Jane Lowok $492 / 212$

Dec. 28,1978 


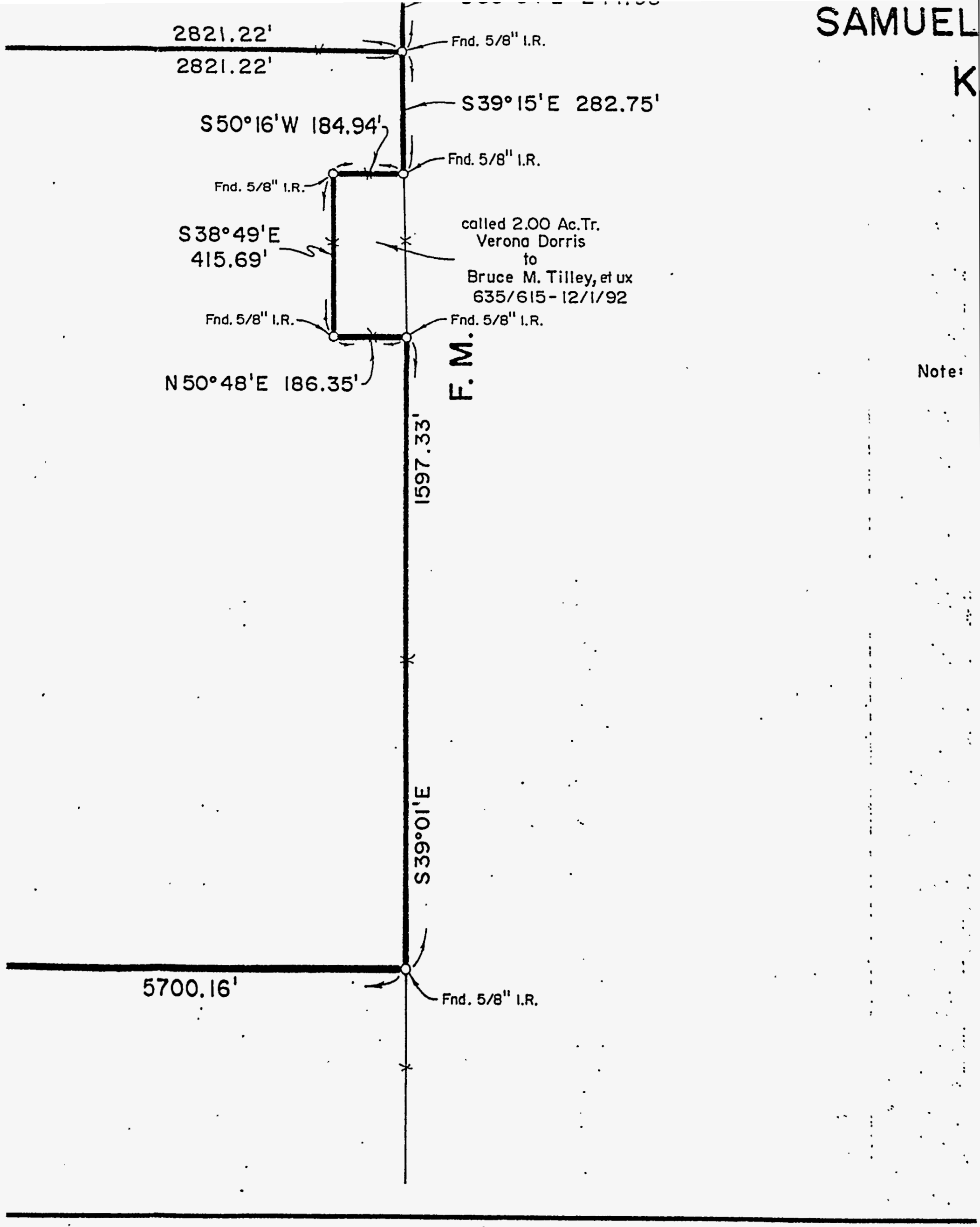




\section{:L A. J. MAYS SURVEY A-212 KARNES COUNTY, TEXAS}

es The bearings shown hereon ore based on the colled bearing between two (2) $5 / 8$ " iron rods found on the southeost line of a 265.98 ocre tract, recorded in Volume 616, Page 770 of the Deed Records of Kornes County, Texas. (Colled $551^{\circ} 14^{\prime} \mathrm{W}$ ) Distances ore surfoce.

Stote of Texas I County of Bee 1

I hereby certify that this plot occurately represents

- survey. mode on the ground under my direction.

George E. Atorris

Registered Professional Land Surveyor No. $826^{\circ}$

Date Nourmbere 11,1994 .

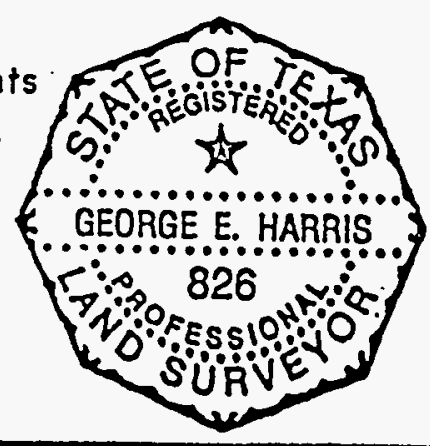
HARRIS ENGINEERING 306 E. CORPUS CHRISTI. BEEVILLE, TEXAS PH. 512-358-1793

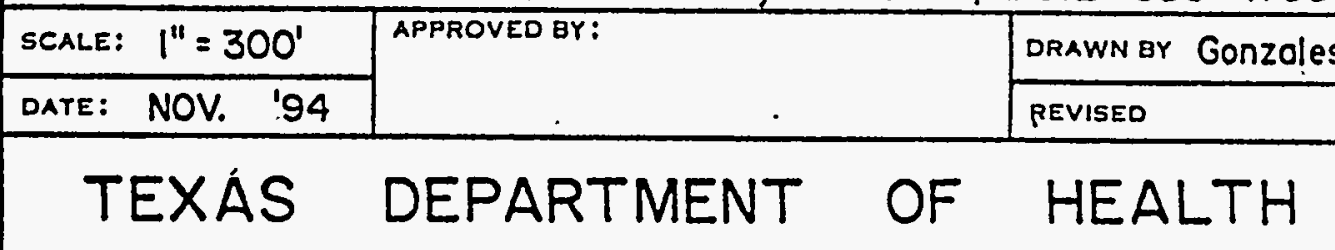




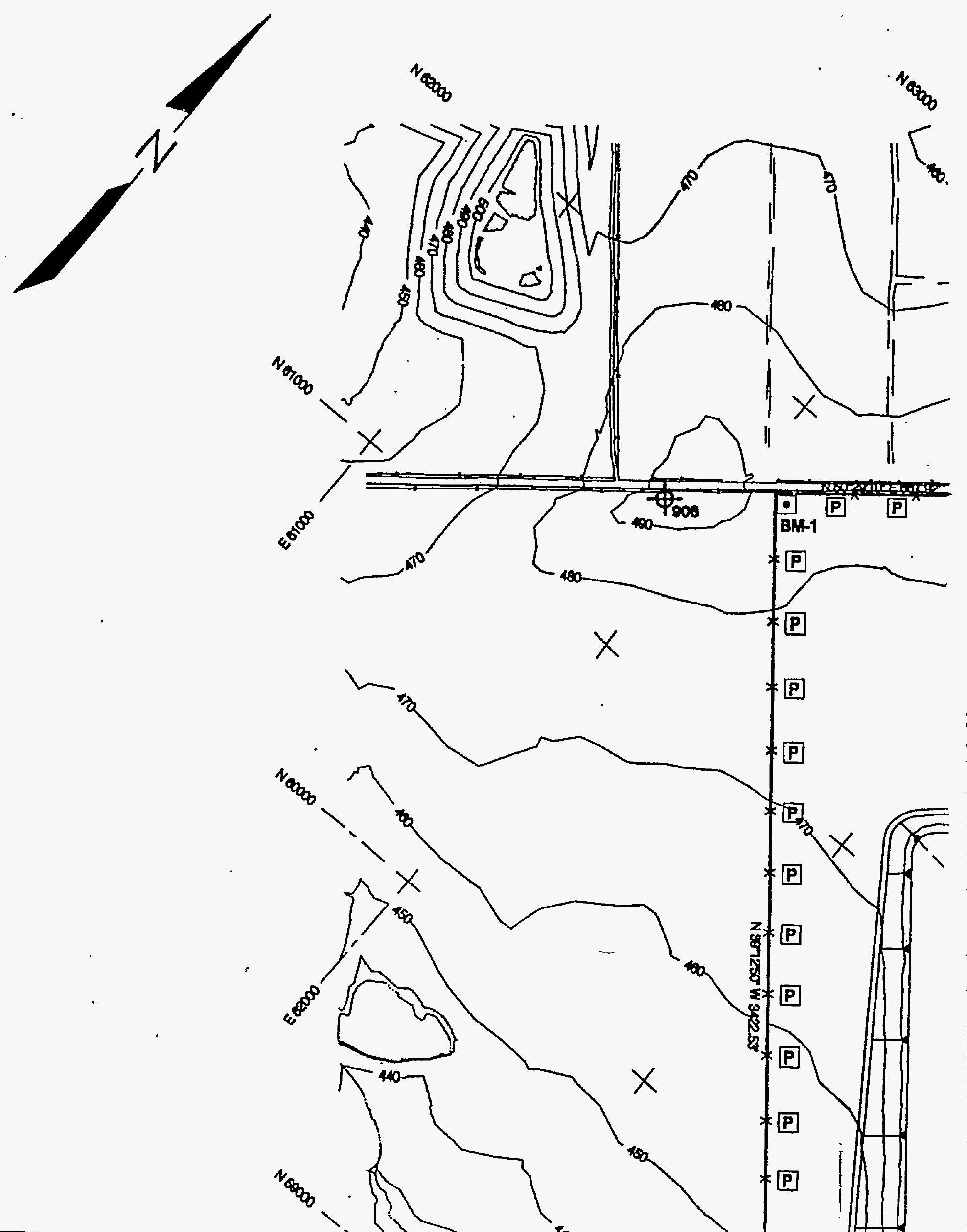




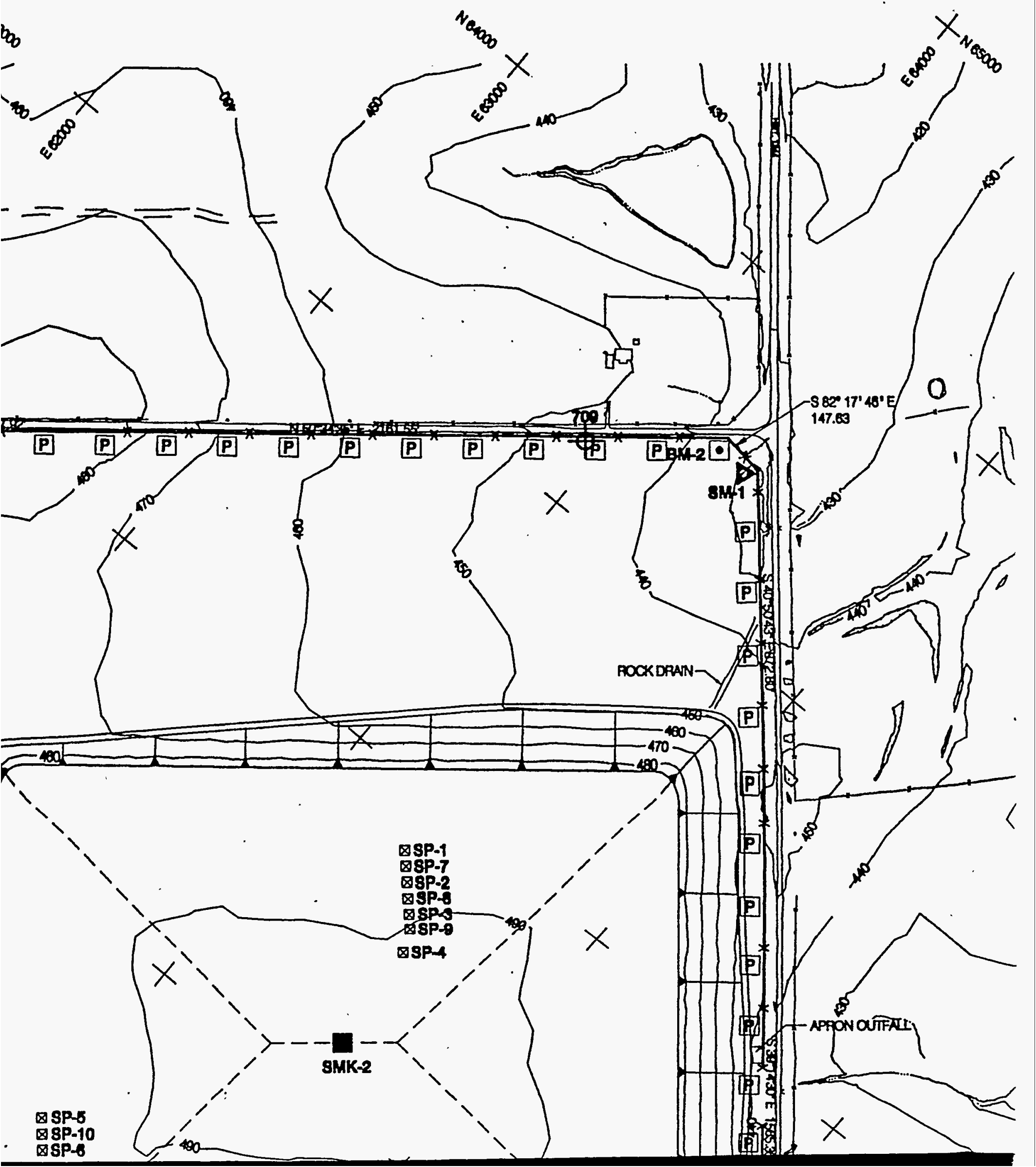




\section{LOCATIONS OF MONUMENTS AND SETTLEMENT PLATES}

\section{SURVEY MONUMENTS}

\begin{tabular}{|c|c|c|}
\hline SYMBOL & NOATHING & EASTING \\
\hline SM-1 & N63,494.88 & $E 64,435.18$ \\
\hline SM-2 & N60,939.03 & $E 66,577.00$ \\
\hline SM-3 & N59,076.98 & $E 64,270.94$ \\
\hline \multicolumn{3}{|c|}{ BOUNDARY MONUMENTS } \\
\hline BM-1 & N61,721.01 & $E 62,113.45$ \\
\hline BM-2 & N $63,514.12$ & $E 64,292.94$ \\
\hline \multicolumn{3}{|c|}{ SETTLEMENT PLATES } \\
\hline SP-1 & N61,819.66 & $E 64.339 .89$ \\
\hline SP-2 & N61,747.31 & $E 64,408.60$ \\
\hline SP-3 & N $61,672.40$ & $E 64,479,80$ \\
\hline SP-4 & N61,559.87 & $E 64,548.83$ \\
\hline SP.5 & N $60,378.15$ & $E 63,999.86$ \\
\hline SP-6 & N60,299.05 & $E 64,068.84$ \\
\hline SP-7 & N 61,783.45 & E 64,373.97 \\
\hline SP-8 & N61,709.88 & $E 64,444.19$ \\
\hline SP-9 & N61,636.05 & $E 64.514 .26$ \\
\hline SP-10 & N 60,338.93 & $E 64,034.96$ \\
\hline
\end{tabular}

\section{LOCATIONS OF SITE MARKERS}

\begin{tabular}{|c|c|c|}
\hline & NORTHING & EASTING \\
\hline SYMBOL & & \\
\hline SMK-1 & N61,118.19 & E 66,426.33 \\
\hline SMK-2 & N 61,180 * & E 64,570 * \\
\hline
\end{tabular}




\section{NOTES}

1. TOPOGRAPHY, PROPERTY UNES, BEARINGS, AND DIMENSIONS ARE FROM CML DESIGN SERMCES, SAN ANTONIO, TEXAS.

2. AERIAL PHOTOGRAPHY WAS PERFORMED IN JUNE 1994. PROPERTY SURVEY WAS PERFORMED IN AUGUST-SEPTMBER 1994.

3. THE CONSTRUCTION GRID COORDINATES SHOWN WERE BASED ON THE PROJECT SURVEY CONTROL POINTS ESTABLISHED IN THE FIELD BY JACOBS ENGINEERING GROUP, INC.; SM-A (N59,387.31, E67,851.16, EL. 429.59) AND SM-B (N61,032.34, E69,864.58, EL 419.47)

4. THE BOUNDARY MONUMENTS AND SURVEY MONUMENTS ARE OFFSET 5 FEET NORTH/SOUTH AND 5 FEET EAST/WEST INSIDE THE LEGAL SITE BOUNDARY.

5. PERIMETER AND ENTRANCE SIGNS ARE LOCATED INSIDE THE DISPOSAL SITE BOUNDARY AT 5 FEET FROM THE FENCE. THE ENTRANCE SIGN IS LOCATED IMMEDIATELY ADJACENT TO THE ENTRANCE GATE.

6. SETTLEMENT PLATES SP-1, SP-2, SP-3, SP-5 AND SP-6 LIE ON TOP OF ORIGINAL TAILINGS BEFORE REMEDIAL ACTION, WHEREAS SP-7 THROUGH SP-10 LIE ON TOP OF THE RADON BARRIER.

\section{LEGEND}




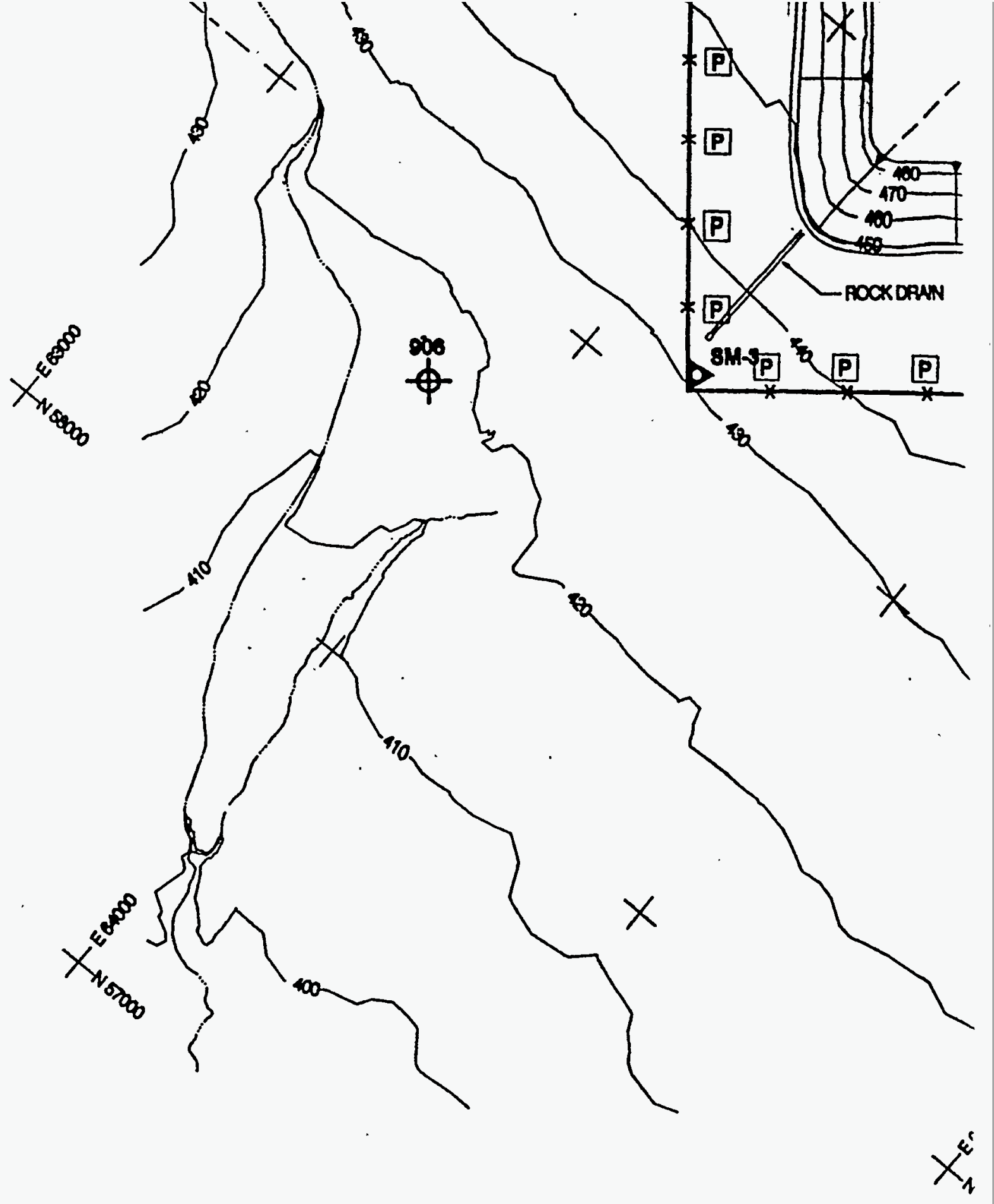




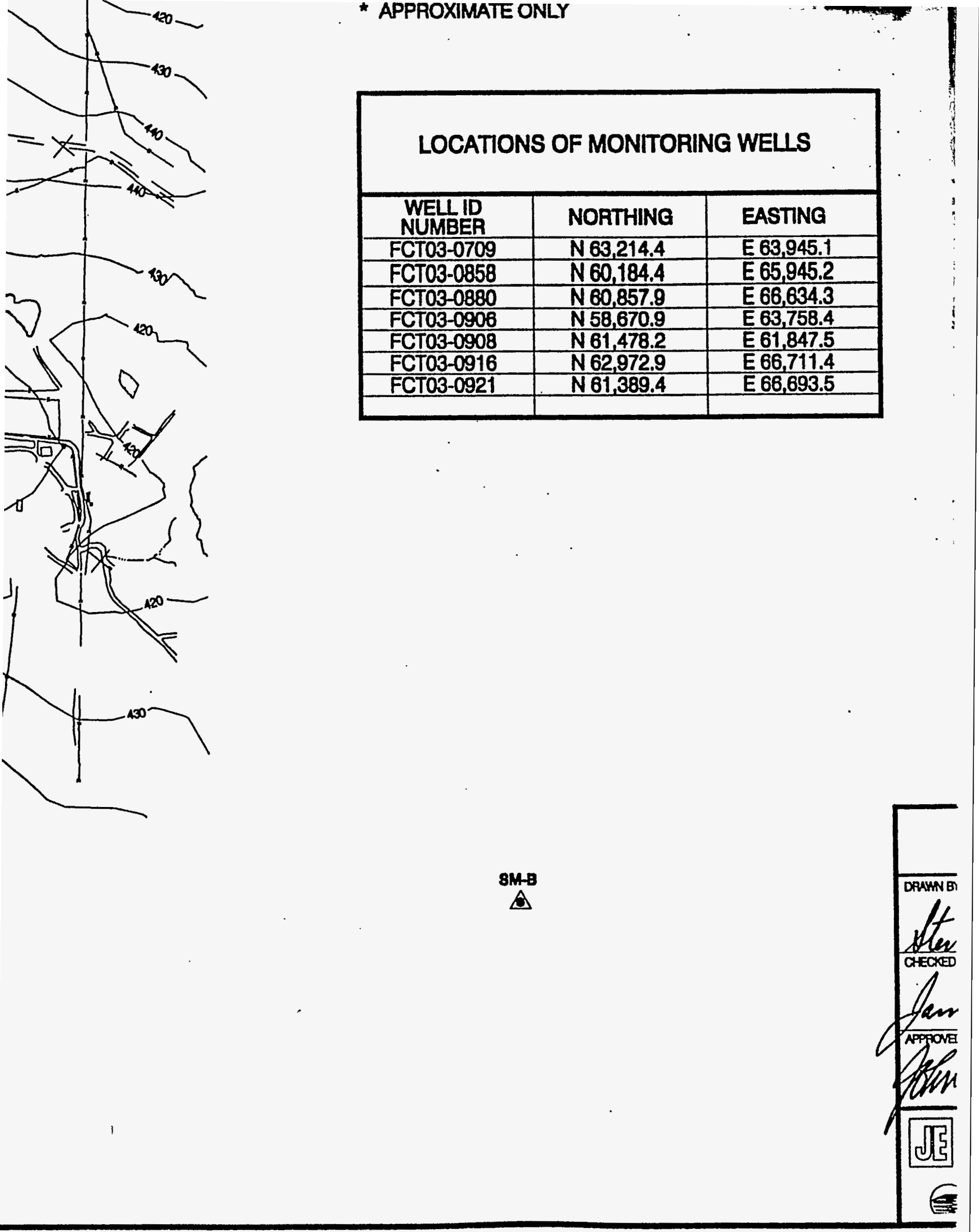


MONITOR WELL

\section{ニニニニニニ～DIRT ROAD}

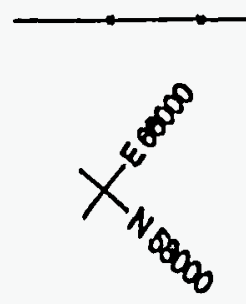

EXISTING FENCE

CONSTRUCTION GRID COOADINATES

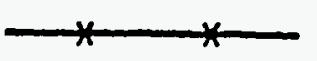

DISPOSAL SITE BOUNDARY AND FENCE

\section{U. S. DEPARTMENT OF ENERGY ALBUQUERQUE, NEW MEXICO}

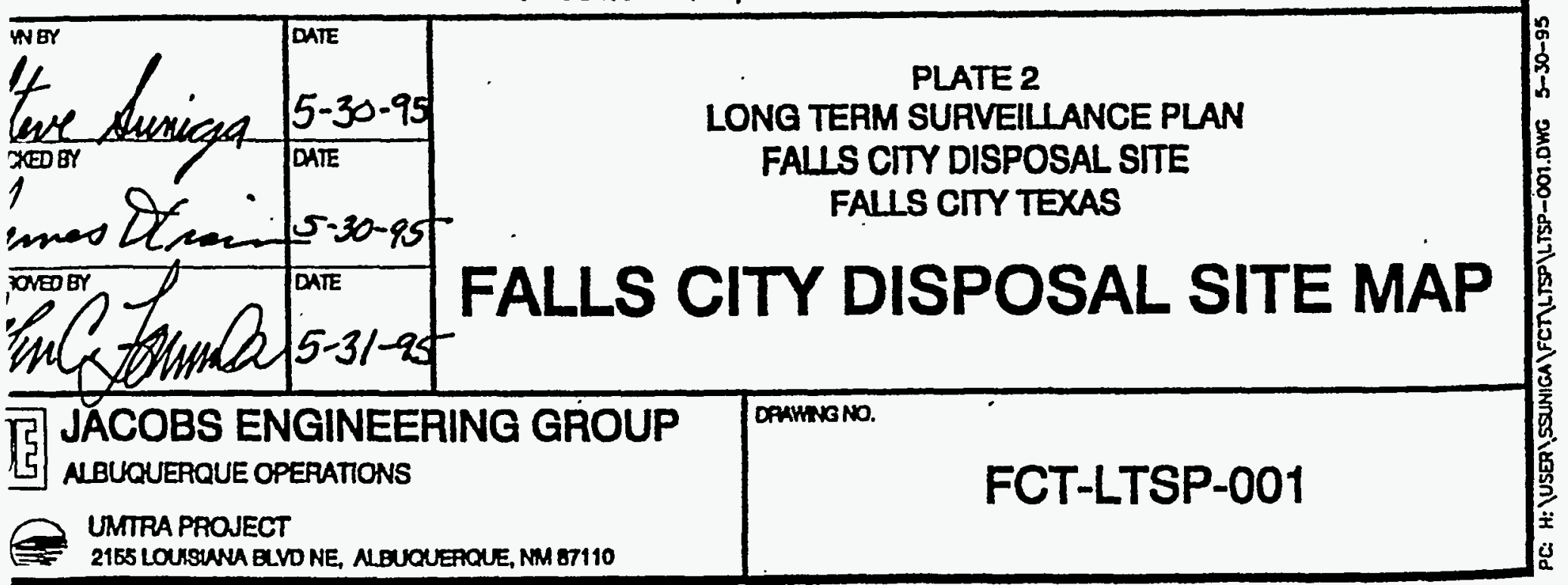

